Securities Disclosure in a Globalizing Market: Who Should Regulate Whom

Author(s): Merritt B. Fox

Source: Michigan Law Review, Vol. 95, No. 8 (Aug., 1997), pp. 2498-2632

Published by: Michigan Law Review Association

Stable URL: http://www.jstor.org/stable/1290126

Accessed: 15-10-2015 14:20 UTC

Your use of the JSTOR archive indicates your acceptance of the Terms \& Conditions of Use, available at http://www.jstor.org/page/ info/about/policies/terms.jsp

JSTOR is a not-for-profit service that helps scholars, researchers, and students discover, use, and build upon a wide range of content in a trusted digital archive. We use information technology and tools to increase productivity and facilitate new forms of scholarship. For more information about JSTOR, please contact support@jstor.org. 


\title{
Securities Disclosure in a Globalizing Market: Who Should Regulate Whom
}

\author{
Merritt B. Fox*
}

\section{TABLE of CONTENTS}

INTRODUCTION ................................ 2501

I. The Process of Globalization .............. 2506

A. Factors Favoring a Global Market ........... 2508

1. Returns to Reallocation of Savings ......... 2508

2. Greater Diversification .................. 2509

B. Factors Favoring National Markets ........... 2512

1. Specialized Information Concentrated

Nationally......................... 2512

2. Currency Exchange Risks .............. 2515

3. Government Impediments to Transnational Investments ........................ 2517

4. Transaction Costs of Trading in Foreign Securities.............................. 2518

C. The Current Extent of Globalization - The Price Dimension ......................... 2519

1. International Capital Asset Pricing Model Studies ................................. 2519

2. Studies of Securities Sharing the Same Underlying Cash Flows ................ 2522

3. Conclusion........................... 2523

D. The Current Extent of Globalization - The Pattern of Holdings Dimension ............. 2523

E. The Future of the Factors Favoring National Markets ............................. 2526

1. Information ......................... 2526

2. Exchange Rates .................... 2529

3. Government Impediments .............. 2530

* Professor of Law, University of Michigan. B.A. 1968, J.D. 1971, Ph.D. (Economics) 1980, Yale. - Ed. The author wishes to express his appreciation for helpful comments on earlier drafts of this article to Professors Richard Friedman, Avery Katz, Larry Kramer, Kyle Logue, and Lynn Stout, Dean Joel Seligman, and participants at the Columbia University Law and Economics Workshop, the University of Michigan Law and Economics Workshop, and the University of Pennsylvania Law and Economics Workshop. Financial support for this project was provided by the Cook Fund of the University of Michigan. 
4. Transaction Costs ...................... 2530

F. Conclusion .................................. 2531

II. The Benefits and Costs of Greater

Disclosure ............................... 2532

A. Benefits of Greater Disclosure .............. 2533

1. Fairness .............................. 2533

2. Risk............................... 2540

3. Efficient Allocation of Resources.......... 2544

B. Costs of Greater Disclosure ................ 2550

1. Private Costs of Disclosure to the Individual Issuer .................................. 2550

2. Costs of Disclosure to Issuers as a Class and to the Economy as a Whole

III. The Stakes of Individual Countries IN The Disclosure of Transnationally Traded ISSUERS

A. The Standard Transaction: Buyer From A;

Transaction Occurs in A; Issuer From B

1. The Stakes for Country A, the Country of the Buyer ................................

2. The Stakes for $\mathrm{B}$, the Country of the Issuer ...................................

3. The Relevance of the Place in Which the Transaction is Executed

B. The Transplant Transaction: Buyer from B; Issuer from B; Transaction Occurs in A.......

1. The Different Nature of the Stakes ........ 2570

2. Country A's Regime Is the More Rigorous: The Market Reputation and Cost Deterrence Effects

3. Country B's Regime Is the More Rigorous: The Regulatory Evasion Effect .............

4. Increased Investor Willingness to Trade on a Country's Market Not a Sound Basis for Imposing Its Regime on Transplant Transactions ................................

C. Issuer Country Transactions: Buyer from A; Issuer from B; Transaction Occurs in B

1. The Nature of Issuer Country

Transactions 
2. The Stakes of Countries A and B: $A$ Comparison Between Issuer Country and Standard Transactions................... 2576

3. Reflections on the Role of Place .......... 2578

IV. The Optimal Apportionment of Regulatory Authority............................... 2580

A. The Recommended Approach .............. 2582

B. Purely Domestic and Transplant Transactions .. 2584

1. Risk Reduction and Resource Allocation Effects ............................. 2584

2. Adding in Trading Volume Effects - First Analysis............................ 2585

3. Adding in Trading Volume Effects Accounting for Intercountry Competition's Impact on Regulatory Content

C. Standard and Issuer Country Transactions .....

1. The Simplified Case: Risk Reduction and Project Choice Efficiency Gains With Initially Capitalizing Firms

2. Ongoing Corporations With Ongoing Disclosure ...........................

D. Additional Considerations Favoring Country B as the Exclusive Regulator of the Disclosure of Its Issuers ................................

1. Special Costs of Different Disclosure Levels for Different Issuers From the Same Country

2. The Reality That Most Transnational Issuers Will Also Have Public Shareholders at Home

E. The Case Against Concurrent Regulation ..... 2606

V. Application to U.S. Policy ................ 2608

A. The Current U.S. Approach ................ 2610

1. Issuer Disclosure Triggered by Primary Market Transactions ...................

2. Issuer Disclosure Triggered by Secondary Market Transactions .................... 2614

3. Conclusion.......................... 2617

B. A Switch to the Issuer Nationality Approach Would Enhance U.S. Welfare................ 2618 1. Selection of Issuers................... 2618 
2. The Prevention of Political Pressures to Lower U.S. Disclosure Requirements to a Suboptimal Level ......................

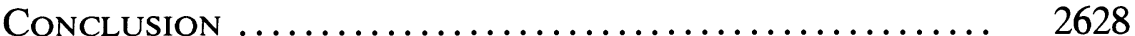

\section{INTRODUCTION}

One of the most dramatic examples of increasing interaction across national boundaries in recent years has been the burgeoning volume of transnational transactions in corporate equities. ${ }^{1}$ Most developed capitalist countries impose affirmative obligations on issuers of corporate equity to disclose certain information about themselves. While these obligations are imposed on issuers, they are triggered by transactions. The growth in transnational transactions is thus increasingly raising difficult issues concerning the reach of differing national regimes. ${ }^{2}$ Given the magnitude of legal resources devoted to compliance with such disclosure regulations, ${ }^{3}$ they promise to feature prominently in the larger discussion of

1. Foreign share transactions on the New York Stock Exchange in 1993 had a total value of \$1.2 trillion. See New York Stock Exchange, Fact Book for the Year 1994, at 89 (1995) [hereinafter 1994 FACr Book]. The total value of share transactions on the New York Stock Exchange in 1993 was approximately $\$ 2.28$ trillion, a figure that must be doubled to compare with the $\$ 1.2$ trillion figure because it counts a purchase and sale as a single transaction. See New York Stock Exchange, Fact Book for the Year 1993, at 7 (1994). Compare an estimate of the 1986 value of transnational securities on the New York Stock Exchange of $\$ 378$ billion, see 1994 FACT BooK, supra, at 89, with a Salomon Brothers estimate of the total value of international equity trading during the same time period of $\$ 750$ billion. See Steve Lohr, Investors Retreating from Foreign Markets, N.Y. TiMES, Dec. 16, 1987, at A1.

2. See infra Part V. For a description of securities regulation regimes in other countries, see Javier Lizardi Calderon \& Samuel Wolff, Mexico, in 10C InTERnational CaPITAL MARKets and Securities Regulation, at 4A-1 (Harold S. Bloomenthal \& Samuel Wolff eds., 1982 \& Supp. July 1991); Jeff G. Cowan \& Richard J. Lachcik, Canada, in 10B INTERnAtional Capital Markets and Securities Regulation, supra, at 4-1 (Supp. Apr. 1992); Georgette Miller, France, in 10C International Capital Markets and SeCurities ReGulation, supra, at 7-1; G.K. Morse, United Kingdom, in 10C InTERnational CaPITAL Markets and Securities Regulation, supra, at 6-1; Eberhard H. Röhm, Germany, in 10D International Capital Markets and Securities Regulation, supra, at 8C-1 (Supp. Dec. 1996); Misao Tatsuta, Japan, in 10D InTernational Capital Markets AND Securities Regulation, supra, at 11-1.

3. One estimate concludes that aggregate expenses for a normal common stock offering range between 1.5 and $2 \%$ of the proceeds of the underwriting. See Louis Loss \& JoEL Seligman, Securities Regulation 339 (3d ed. 1989) (citing William J. Grant, Jr., Overview of the Underwriting Process, in Securities Underwriting: A Practitioners' Guide 25, 32-33 (Kenneth J. Bialkin \& William J. Grant, Jr. eds., 1985)). Thus, in 1995 alone, approximately $\$ 1.6$ billion ( $2 \%$ of $\$ 81.7$ billion) was devoted to compliance with the U.S. securities regime. See New York Stock Exchange, Fact Book for the Year 1995, at 9 (1996) 
the role of national legal regimes in a world of growing interdependence. ${ }^{4}$

A securities transaction has several dimensions of nationality: the nationality of the issuer, the place of execution, the residence of the buyer and, if it is a secondary transaction, the residence of the seller. A transaction is transnational if at least one of these dimensions involves a country different from the country of the other dimensions. Each of the countries associated with a transnational transaction can make a claim for imposing its regime on the issuer whose security is involved. This article addresses the question of which of these countries should have the authority to regulate the issuer's disclosures.

The answer to this complex question is of growing importance for the proper functioning of the global economy. Strong arguments can be made that appropriate disclosure regulation corrects market failures that otherwise would lead to misallocations of capital and management inefficiencies. Disclosure regulations can also increase investor utility under certain circumstances. Compliance with these regulations, however, is costly, and the mere prospect of their application can deter potential transactions that would be beneficial to the parties involved. Complicating the matter further, the proper balance between these considerations of benefit and cost is not the same for all issuers around the world under all circumstances. Also, for any issuer of a given country and set of circumstances, knowledge about what the appropriate balance is will not be evenly spread around the world, nor will there be a consensus about it, even among the persons who are the best informed.

4. The transnational reach of domestic regulation is an essential part of the modern approach to the subject area traditionally labeled as "international law." Most of the cases and commentary until now have involved just a few areas of substantive regulation, most conspicuously criminal law, welfare legislation for seamen, antitrust regulation, export controls, and the antifraud provisions of securities laws. See, e.g., JohN H. BARTON \& BART S. Fisher, INTERNATIONAL TRADE AND INVESTMENT: REgULATING INTERNATIONAL BUSINESS 813-53 (1986); Myres S. McDougal \& W. Michael Reisman, International LaW in ContemPORARy Perspective: The Public Order of the World Community 1295-392 (1981); Covey T. Oliver et al., CASES and Materials on the International Legal System 135-91 (1995); Henry J. Steiner et al., Transnational Legal Problems 885-983 (4th ed. 1994); Alan C. Swan \& John F. Murphy, Cases and Materials on the Regulation OF INTERNATIONAL BuSINESS AND ECONOMIC RELATIONS 515-704 (1991).

Recently the issue of the transnational impact of domestic regulation has come up in a more indirect fashion in the areas of environmental regulation and labor standards. This involves the situation where country $A$ imposes more stringent environmental or labor regulations on producers operating within its territory than does country $B$ on producers operating within its territory. $A$, in order to prevent $B$ 's producers from having a cost advantage over $A$ 's producers, prohibits imports of products from $B$ unless the producers conform with $A$ 's more stringent standards. For an overview of such issues, see JOHN H. JACKSON ET AL., Legal Problems of International Economic Relations 559-95 (3d ed. 1995). 
Proper apportionment of the authority to regulate involves consideration of which country's officials are likely to be most knowledgeable about the benefits and costs of disclosure for a given issuer and circumstance. Also, given the remaining uncertainty as to the proper trade-off, the proper apportionment of authority requires consideration of on which authorities the benefits of a good decision and the harms of a bad one will be concentrated. The issue ultimately requires hoeing the narrow row between permitting the needless evasion of valuable rules that correct market failures and the unnecessary expense and frustration of hindering beneficial transactions. The global aggregate of economic activity impacted by this apportionment of authority is enormous. The gains from getting the balance right are potentially very large. Yet, to date, the question has not been a subject of much sustained, serious academic inquiry. ${ }^{5}$

This article approaches the question of which countries should regulate which issuers with the goal of determining what apportionment of regulatory authority would most enhance global economic welfare. 6 While this goal of maximizing economic welfare drives the analysis, the recommended apportionment is clearly within the range that would be permitted under international law. The analysis also suggests that an international agreement on a single regime for all issuers around the world would not, for the medium-term future anyway, enhance global welfare as much as properly apportioned regulation by national regimes.

5. There are some notable exceptions. For two less theoretical articles backing traditional investor protection, see James A. Fanto, The Absence of Cross-Cultural Communication: SEC Mandatory Disclosure and Foreign Corporate Governance, 17 Nw. J. INTL. L. \& Bus. 119 (1996); J. William Hicks, Protection of Individual Investors Under U.S. Securities Laws: The Impact of International Regulatory Competition, 1 Global LeGal StUd. J. 431 (1994). For a less theoretical article taking a position closer to the issuer-nationality approach that I advocate here, see Edward F. Greene et al., Hegemony or Deference: U.S. Disclosure Requirements in the International Capital Markets, 50 Bus. Law. 413 (1995). For other, more theoretical works in this area, see Stephen J. Choi \& Andrew T. Guzman, The Dangerous Extraterritoriality of American Securities Law, 17 Nw. J. INTL. L. \& Bus. 207 (1996); Stephen J. Choi \& Andrew T. Guzman, National Laws, International Money: Regulation in a Global Capital Market, 65 Fordham L. Rev. 1855 (1997). Choi and Guzman agree with me that foreign issuers whose shares are sold to U.S. residents or are traded in the United States should not necessarily be subjected to the U.S. regime. They come to significantly different conclusions, however, in that they favor giving issuers the freedom to choose the jurisdiction governing their disclosure. For reasons discussed infra in sections IV.B.3 and V.B.2, I believe that such freedom would lead to an undesirable "race to the bottom" in the content of national disclosure regimes.

6. Distributional issues, in the sense of redistribution from rich persons to poor persons or vice versa, are not at the heart of this question. As will be developed further, see infra notes 71,103 and accompanying text, whatever approach to regulating disclosure is adopted, it will not likely have any systematic wealth redistribution effect. 
The market for a security is "fully global" if it matters little to the probability of a transaction taking place whether the issuer, the parties, and the place of execution are of the same country or different ones. Part I examines the extent of globalization today and the process by which it is occurring. It considers trends in the factors favoring globalization and in the counterfactors resisting it. Part I concludes that while the market today is by no means fully global, it will, over the next decade or so, move substantially in that direction for all issuers of any significance, absent obstruction by nationally based disclosure regulation.

Parts II, III and IV address the question of which country or countries should regulate which issuers. Part II considers what are as a general matter the benefits and costs of an issuer disclosing more about itself. Part III examines how these benefits and costs are divided up among the countries related to any transnational transaction involving an issuer's shares. It considers three dimensions of nationality: the residence of the buyer, ${ }^{7}$ the place of the transaction, and the nationality of the issuer. ${ }^{8}$ The issuer's disclosure behavior affects each of these countries. The analysis of how each is affected reveals the distribution of the disclosure behavior's benefits and costs, and hence of the benefits and costs of the regulations that govern it.

Given this, Part IV considers what apportionment of regulatory authority among these countries would lead the issuer to disclose at a level closest to that which would maximize global economic welfare. It concludes that each country should be the exclusive regulator of all issuers of its nationality, regardless of where in the world the shares of that country's issuers are offered and traded, to whom they are offered, and among whom they are traded.

7. In a primary transaction, the issuer is the seller. The nationality of the issuer and seller thus do not constitute separate dimensions of nationality. In a secondary transaction, the seller is someone different than the issuer. This additional fourth dimension of nationality will not be considered in this analysis, however, because the secondary transaction seller's direct stake in issuer disclosure - being protected from making a damaging securities portfolio adjustment as a result of being poorly informed - is essentially the same as the buyer's stake. The only difference is formalistic. The portfolio adjustment the seller is choosing is whether or not to sell, and the portfolio adjustment the buyer is choosing is whether or not to buy. The policy issues raised by the buyer dimension and seller dimension of nationality are thus identical and do not merit the additional complexity that separate treatment would involve.

8. The nationality of an issuer would be determined by where the issuer as a firm has its center of gravity. Factors important to this determination include the location of the entrepreneurs who formed the enterprise, the location of the current headquarters, and the location where the bulk of its operations are conducted. See infra note 9 and accompanying text. The issuer's jurisdiction of incorporation would not be a factor in this determination, nor would the residency of its shareholders. 
Part V is a preliminary application of these findings to U.S. policy. In the U.S. selection of which issuers onto which to impose its regime, the traditional focus has been on the national residence of the buyer. The articulated rationale for this selection has been "investor protection": the protection of U.S. investors from making damaging securities choices as a result of being poorly informed. This rationale leads directly to the principle that the only transactions that should trigger U.S. disclosure regulation are those involving U.S. investors, but that they should do so even in cases where the issuer involved already is complying with some other country's disclosure regime.

Recently, however, the SEC has proposed a different, "capital market protection" approach. This approach maintains the goal of protecting certain investors from being poorly informed but reformulates the class of persons protected to consist of all purchasers in the U.S. market, wherever their residence, but not U.S. purchasers in foreign markets. Thus, the SEC is proposing a shift in focus to the place of the transaction.

The analysis that this article employs, however, shows that neither the traditional investor protection approach nor the proposed market protection approach is in the enlightened self-interest of the United States. In contrast, I conclude that the United States should apply its regime only to issuers of U.S. nationality, but do so regardless of the location of transactions in the issuer's shares and regardless of who the buyers are. This set of issuers, of course, is exactly the same set of issuers the United States would regulate under the optimal apportionment authority at the international level recommended here.

Globalization is an occasion for a fundamental reassessment of the proper function of mandatory disclosure, a reassessment that can benefit from our greatly increased sophistication about financial economics since the passage of the securities acts in the 1930s. As Part II demonstrates, the traditional investor protection rationale misidentifies the most important stake that a country can have in the disclosure practices of an issuer: the efficiency gains in its real economy that can be derived from better capital allocation and more effective disciplining of managers to act in the best interests of shareholders. This misidentification was relatively harmless in an era of primarily domestic transactions, because investor protection and efficiency considerations each led to applying the rules to the same set of issuers. Now that the United States must make decisions concerning the reach of the U.S. regime to issuers whose 
shares are involved in transnational transactions, however, the error can be much more costly.

The gains and costs of applying a particular set of disclosure rules to a given issuer are, as shown in Part III, primarily concentrated within the country with which the issuer is most closely associated - that is, the country of which it is a "national." Despite the rise of "multinational" corporations, the bulk of the world's economic activity is still undertaken by enterprises (including many that are labeled "multinational") for which one country is the residence of the entrepreneurs that took the enterprise public, the place of its headquarters, and the location of the largest portion of its operations. ${ }^{9}$ With the increasing globalization of financial information and ease of effecting transactions abroad, the mobility of investment funds is increasing dramatically. For at least the next few decades this is likely to make investors' portfolios more international than the issuers in which they invest. This increasing internationalization of portfolios should not obscure the fact that, as the analysis of national stakes shows, it is still in the best interests of the United States and of the global economy as a whole for disclosure regulation to be undertaken at the national level and for the United States to apply its regime only to those issuers that have their economic center of gravity in the United States.

\section{The Process of Globalization}

An essential first step to analyzing which countries should regulate which issuers is understanding why transnational securities transactions take place and what their impact is. By definition, the existence of transnational transactions in corporate equities means that the market for the securities involved reaches beyond the boundaries of the country of the issuer. Such transactions have to reach a certain level of intensity, however, before their impact is sufficient for us to say that the whole world forms "one market" in the same way that a country has traditionally formed one market for the equities of its nationally known issuers.

The extent of the impact of transnational transactions in forming a one-world market can be measured along two dimensions:

9. In 1990, profits from foreign operations of U.S. corporations amounted to only about one-sixth of all corporate profits. See Surv. CuRrent Bus., Dec. 1992, at 14 tbl.6.16C. In 1989 , overseas assets of U.S. corporations designated as "multinational" were only about one-fifth of their total assets. See Jeffrey H. Lowe \& Raymond J. Mataloni, Jr., U.S. Direct Investment Abroad: 1989 Benchmark Survey Results, Surv. Current Bus., Oct. 1991, at 29 tbl.1. 
price and pattern of investor holdings. The price dimension concerns the extent to which such transnational transactions assure that the "law of one price" applies - that is, that a security promising its holder a given future cash flow will have the same price whatever the nationality of its issuer or of the exchange on which it is principally traded. ${ }^{10}$ The price dimension is often referred to by financial economists as "integration."11

The pattern of holdings dimension concerns the extent to which transnational transactions result in the typical investor around the world holding an equity portfolio containing shares of issuers of different countries roughly in proportion to the countries' respective total market capitalizations, as opposed to a portfolio primarily containing shares of issuers of her own country. ${ }^{12}$ Putting it another way, the market for a security is "fully global" along this dimension if it matters little to the probability of a transaction taking place whether the issuer, the parties, and the place of execution are of the same country or different ones.

The extent to which the market for corporate equities is fully global along both the price and holdings dimensions depends on two contending sets of factors considered below. Factors favoring a global market in large part reflect two constant pressures inherent in the economics of investing: the desire by investors to earn high

10. More precisely, the law of one price is said to apply where a security with a future cash flow determined by a given probability distribution - conditional on the publicly available information known by the best informed investors - has the same price whatever the nationality of the issuer or exchange on which it is traded.

11. See infra notes $37-46$ and accompanying text.

12. I use the word "roughly" because, as we shall see, differences among investors of different national residences may call for deviations from these proportions even in a market for securities in which distance otherwise means nothing. Relevant differences among investors include their tax situation, their consumption of nontraded goods in a world of unpredictable inflation and deviations of currency exchange changes from purchasing power equity, and their need to hedge against risks associated with human capital. See infra section I.D.

For the market for securities to be fully global along the holdings dimension, the average U.S. and Japanese investors would both have to have roughly $40 \%$ of their share portfolio in U.S. stocks and $28 \%$ in Japanese stocks. This estimate is derived from figures showing that in 1995 , the total capitalization of all the world's publicly traded issuers was estimated at $\$ 17$ trillion, the total capitalization of U.S. issuers was about $\$ 7$ trillion, and the total capitalization of Japanese publicly traded issuers was about $\$ 4.7$ trillion. See JAmEs L. Cochrane et AL., Foreign Eouities and U.S. Investors: Breaking Down the Barriers SeparatING SupPly AND Demand 1 (New York Stock Exch. Working Paper 95-04, 1995); Big Board Capitalization Hits a Record \$5 Trillion, WALL ST. J., May 9, 1995, at C17. In fact, however, investors display an extreme home bias. For example, at least as recently as 1989 , U.S. investors on average held $93.8 \%$ of their portfolios in U.S.-issuer stocks and only $1.3 \%$ in Japanese-issuer stocks, and Japanese investors on average held only $0.3 \%$ of their portfolios in U.S.-issuer stocks and $98.1 \%$ in Japanese-issuer stocks. See Kenneth R. French \& James M. Poterba, Investor Diversification and International Equity Markets, АM. ECON. REv., May 1991 , at 222 \& tbl.1. 
expected returns and the desire to reduce risk through diversification. The counterfactors to a global market are barriers to these pressures that traditionally have been sufficiently high to result in the market for most equities being largely segmented along national lines. A weakening of these counterfactors in recent decades has led to the market for corporate equities becoming more globalized.

Part I addresses the current status of market globalization and its potential in the next few decades. The extent of market globalization along the price dimension is unclear; some financial economists argue that it is already fully global, and others argue that it is not. ${ }^{13}$ As for the pattern of holdings dimension, however, the market is clearly far from fully global. Full globalization would involve a manifold increase in transnational share transactions. Rather than being a small fraction of purely domestic transactions, transnational transactions would come to dominate them. Such a development would profoundly impact national regulation of issuer disclosure. It is a development that ultimately will have to be faced, quite possibly in the next decade or so, because the counterfactors favoring segmented national markets will continue to weaken while factors favoring a global one will continue inherently strong.

\section{A. Factors Favoring a Global Market \\ 1. Returns to Reallocation of Savings}

The existence of differences among nations in domestic savings relative to the quality of available opportunities for domestic real investment works in favor of a global securities market. ${ }^{14}$ Real investment opportunities in each nation display diminishing marginal returns. The proposed projects that constitute any given nation's set of domestic real investment opportunities are bound to have differing earnings prospects. If projects are implemented in rank order of their prospects, the more of a nation's projects that are implemented - that is, the greater the amount of total domestic real investment - the lower the return on the marginal project.

The amount of available domestic savings and the sets of proposed domestic investment projects are unlikely to be distributed

13. See infra section I.C.

14. Real (as opposed to financial) investment involves the use of resources such as skilled labor, machinery, bricks, and mortar to create new capacity to produce a particular good or service. Financial investment involves the acquisition of rights to receive cash returns - for example, the purchase of a share or bond, the lending of money, or the deposit of money in an interest-bearing savings account. 
among nations such that, if there were no transnational investment and each nation invested all its domestic savings in just its projects, the expected return on the marginal project of each nation would be exactly the same. If country $A$ 's marginal project would have, in the absence of transnational investment, a lower expected rate of return than would country $B$ 's marginal project, country $A$ has more savings relative to the quality of its investment opportunities than country $B .{ }^{15}$ A reallocation of savings for investment from $A$ to $B$ reduces the number of projects implemented in $A$ and increases the number of projects implemented in $B$. This enhances global economic efficiency because the projects that go unimplemented in $A$ have a lower expected return than the resulting additional ones that are implemented in $B$. As long as a shift of funds from $A$ to $B$ will have this result, there will exist incentives for persons with savings in $A$ to invest them in $B$.

The market purchase of the securities of the issuer of one nation by an investor in another nation is one of the ways that transnational reallocations of savings occur. There are other institutions through which reallocations occur as well, such as internal financial flows of multinational corporations engaging in direct investment, bank lending, private block purchases of securities, and even the purchase of government debt. But publicly traded securities in an international market, just like those in a domestic market, have the advantages that they are liquid and facilitate investor diversification.

\section{Greater Diversification}

The future return on most securities is probabilistic, not certain, and so each has a certain riskiness associated with it. Global investing offers investors a way of reducing the negative impact of this riskiness to their welfare more than is possible with exclusively domestic investing. To understand why requires a brief diversion into

15. A related phenomenon has been the continuing U.S. trade deficit, which creates dollars abroad in need of investment. In essence, the United States, with its chronic federal budget deficit and low private savings rate, has a low amount of domestically generated savings relative to its investment opportunities, which means that there are incentives for foreign investors to invest in U.S. securities. In 1994, for example, the dollar volume of shares purchased by foreigners from U.S. residents on the New York Stock Exchange exceeded the dollar volume of shares purchased on the Exchange by U.S. residents from foreigners by an estimated $\$ 7.7$ billion. See 1994 FACr BooK, supra note 1, at 89 (basing its estimation on an annualized projection of the figure for the first nine months). This represented $16 \%$ of the total capital inflow into the United States in 1994. See Russell B. Scholl, The International Investment Position of the United States in 1994, Surv. Current Bus., June 1995, at 52, $56-57$ $\&$ tbl.J. 
the theory of portfolio choice, a pillar of the modern approach to finance.

Portfolio choice theory teaches the investor to focus on what the acquisition of a given security does to his whole portfolio of securities rather than on the security's characteristics in isolation. ${ }^{16}$ The critical lesson of portfolio choice theory is that holding a diversified set of risky securities results in lower risk for any given level of expected return. ${ }^{17}$ The expected return of a portfolio is the aggregate of the expected returns of its individual securities. The variance of a portfolio is not, however, the aggregate of the variances of its individual securities, because the actual returns of some of the securities will likely exceed their expected returns and the actual returns of others will likely fall short of their expected returns. Consequently, the deviations of the securities that perform better than expected and the securities that perform worse than expected will, to one extent or another, cancel each other out. By diversifying in accordance with the dictates of portfolio theory, the investor maximizes, for any given level of portfolio expected return, the extent to which this type of canceling out is likely to occur.

There are limits, however, to the effectiveness of diversification for reducing risk. This is most easily seen in terms of a simplified model of portfolio choice theory that focuses on the correlation between return on each individual risky security and the return on the market of securities as a whole. ${ }^{18}$

16. Theories of individual investment behavior assume that the purpose of saving and investment is to consume the results of the investments at the end of the investment period. Because funds are fungible, whatever the combination of gains and losses on the investments in individual securities, all that counts is the total. Portfolio choice theory tells the investor how to compose a portfolio at the beginning of the investment period that will maximize the expected utility he will derive from the end-of-period value of this invested wealth (the means of his consumption at that time). If we assume that an investor is a rational maximizer of his expected utility, we can also use the theory to predict his behavior.

17. Investors are typically assumed to be "risk averse" - that is, they like expected return and dislike risk. Thus, for any given level of expected return, the lower a portfolio's risk the better. The assumption of risk aversion is in turn derived from an assumption that the investor will derive declining marginal utility from consuming end-of-period wealth - that is, each successive dollar of increasing wealth adds less to his total utility. Risk aversion occurs because - compared to the expected utility from a given level of end-of-period wealth known with certainty - the chance of a return of one dollar over the expected level does not compensate for an equal chance of a return of one dollar under the expected level. Thus, in a choice between two portfolios with differing risk, the investor will choose the riskier one only if it has a sufficiently higher expected return to compensate him for the disutility he associates with the greater risk.

18. This model was originally developed by Sharpe. See William F. Sharpe, A Simplified Model for Portfolio Analysis, 9 MGMT. ScI. 277 (1963). For a nontechnical exposition of this model, see James H. Lorie et Al., The Stock Market: Theories and Evidence 108-31 (2d ed. 1985). 
Each security has two kinds of riskiness associated with it: unsystematic or "alpha" risk, the portion of the security's variance that has a zero correlation with the market, and systematic or "beta" risk, the portion of its variance that is perfectly correlated with the market. Unsystematic risk results from factors specific in their effects to the issuer or its industry - for example, uncertainty concerning the quality of an issuer's management. Systematic risk results from factors affecting all issuers whose securities are traded in the market - for example, uncertainty concerning future interest rates. Sufficient diversification can essentially eliminate the contribution of the unsystematic risk of individual securities to a portfolio's overall risk, because the deviations of the individual securities are due to factors unrelated to each other and will cancel each other out. Diversification cannot eliminate the systematic risk of the individual securities, however, because, to the extent that individual securities deviate from their expected returns due to factors causing systematic risk, generally all securities deviate in the same direction.

Global investing offers investors an opportunity to construct a portfolio with lower risk for any given level of expected return. The less each issuer in a market shares in common with the others, the smaller the proportion of systematic risk and the higher the proportion of unsystematic risk. Issuers worldwide share less in common with each other than issuers of a given nation share in common with each other. Thus, if the relevant securities market is global rather than merely national, a larger proportion of each issuer's variance will constitute unsystematic risk, and diversification will further reduce portfolio risk.

The concern with diversification highlights that capital markets not only decide which proposed real investment projects should be implemented, but also who will bear the risk resulting from uncertainty concerning the investments' future returns. Two modifications of the simple model that views transnational investment simply as reallocation of savings flow from this observation. First, the desirability of a given project now depends not only on its expected return but also on its risk characteristics. Second, investors' beliefs concerning the probability distributions of the returns on available securities and investors' needs for diversification, not the amount of savings reallocated transnationally, determine the level of transnational transactions as a proportion of all transactions. If one nation consistently has more savings relative to its real investment opportunities than another, its investors will accumulate a 
larger absolute share of the joint pool of securities of the two nations. However, the proportions of the securities of the two nations that the investors of each would hold in their portfolios will depend on their respective beliefs. ${ }^{19}$ Transnational transactions, through their capacity to reallocate risk in this fashion, have the potential to add significantly to global economic growth as the increase in the possibilities for diversification leads persons to shift to higher expected return investments despite their higher individual variances.

\section{B. Factors Favoring National Markets}

\section{Specialized Information Concentrated Nationally}

Finance theorists often assume that all investors share identical beliefs concerning the probability distribution of the future returns of the available securities. This assumption is useful for understanding certain aspects of investor behavior. It permits the construction of testable models relating securities prices to systematic risk. ${ }^{20}$ It also permits the demonstration that a totally passive investor, who has no specific information concerning the future prospects of available securities, can minimize risk for any given expected return simply by randomly choosing a sufficiently large number of different securities from all the securities available in the market. ${ }^{21}$

In reality, however, investors in different countries still possess significantly different bodies of information, despite the trend toward information globalization. The assumption of identical beliefs in the face of this reality obscures our view of two other aspects of investor behavior that have significantly hindered complete globalization of the market for equities, at least along the pattern of holdings dimension. ${ }^{22}$ First, for the totally passive investor to be willing

19. If, as most finance models commonly assume, investors' beliefs were all identical, the proportions would be identical. The larger absolute amount of transnational investment by the investors of the nation with relatively greater savings will be counterbalanced by the smaller absolute amount of such investment by investors in the other nation.

20. See infra section I.C.1.

21. See infra section I.A.2.

22. Investors in all the larger developed capitalist countries still hold the bulk of their equity portfolios in home country issuers. See infra section I.D. Prominent financial economists have suggested for some time that this "home country bias" is related to differences between the information investors possess concerning home country issuers and that concerning foreign issuers. See, e.g., Martin Feldstein \& Charles Horioka, Domestic Savings and International Capital Flows, 90 ECON. J. 314, 316, 321 (1980) (finding a high correlation between marginal increases in domestic savings and in domestic investment and attributing these in part to investors' greater uncertainty concerning foreign issuers due to less information); Martin Feldstein, Domestic Saving and International Capital Movements in the Long 
to undertake the strategy of randomly choosing securities, she needs basic faith in the market pricing of the securities from which she makes her selection. This faith arises from a level of familiarity that, for many of today's investors, is still attained only for the domestic market. Second, some investors ("speculators") choose their portfolios on the basis of their own beliefs, not randomly. These beliefs, in turn, are based on specialized information not possessed by all participants. ${ }^{23}$ Speculators are likely to do better concentrat-

Run and the Short Run, 21 EUR. ECON. REv. 129, 130-31 \& 148 n.27 (1983) (finding substantial imperfections in the international capital market and attributing them in part to investors having a higher subjective variance on foreign returns due to less information); Robert $\mathrm{E}$. Lucas, Jr., Interest Rates and Currency Prices in a Two-Country World, $10 \mathrm{~J}$. MONETARY ECON. 335, 357 (1983) (explaining home bias as the result of the local nature of information but noting the lack of models that even begin to explain the relationship).

More recently, scholars have begun to study this relationship between local information and home bias in more formal ways, constructing theoretical models and investigating it empirically. Cooper and Kaplanis, for example, undertake an empirical study that rejects, as a sufficient explanation of home bias, inflation hedging and observable proportionate deadweight costs, such as withholding taxes on dividends and the extra management fees that funds charge for investing abroad. By process of elimination, they cite information asymmetries as the most likely alternative explanation. See Ian Cooper \& Evi Kaplanis, Home Bias in Equity Portfolios, Inflation Hedging, and International Capital Market Equilibrium, 7 REV. Fin. STUD. 45 (1994).

Kang and Stulz, in a recent paper, construct three models, each based on a different factor that could generate home bias: (i) an up front lump sum cost to an investor, such as basic knowledge acquisition costs about a foreign country, before she is willing to begin investing in shares of its issuers; (ii) observable deadweight costs that are proportionate to the amount invested, such as dividend withholding taxes or extra management fees; and (iii) information asymmetries. Using Japan, which has particularly easily available data about the foreign ownership of the shares of Japanese issuers, Kang and Stulz show that non-Japanese investors have a stronger home bias against small Japanese issuers than against large ones. They also show that non-Japanese investor portfolios of Japanese stocks underperformed the Japanese market as a whole. These results, they conclude, are consistent with a combination of the upfront lump sum cost of knowledge acquisition model and a simple extension of the information asymmetry model, which posits that because less is known by foreigners about the smaller issuers, the asymmetry with respect to them is greater. Kang and Stulz conclude that their results are inconsistent with the proportional deadweight loss model. See Jung-Koo Kang \& Rene M. Stulz, Why Is There Home Bias? An Analysis of Foreign Portfolio Equity Ownership in Japan (May 1995) (unpublished manuscript, on file with author).

French and Poterba suggest that information asymmetry-related "behavioral finance" theories can shed light on the home bias phenomenon. For one such explanation of home bias, they cite work by Robert Shiller showing that investors in Japan and the United States were each relatively more optimistic in their forecasts of the returns from their home country issuers than of the returns from the issuers of the other country. French and Poterba suggest that such biases, whatever their origins, can persist for a long time, even if risk-adjusted expected returns (presumably involving expectations conditional on all knowledge available somewhere in the world) are equal in the two countries. This persistence is due to the ineffectiveness of feedback in correcting the biases. The problem is that the use of historical actual returns to estimate historical expected returns is plagued by large statistical uncertainties. As a second behavioral explanation of home bias, French and Poterba suggest that investors, due to a lack of knowledge about foreign markets, institutions, and firms, regard investments in foreign stocks as "unfamiliar gambles" and impute to them a special kind of extra, apparently undiversifiable, "risk" even when they assign identical probability distributions to foreign and domestic stock. See French \& Poterba, supra note 12, at 225.

23. This use of the term speculator covers both (i) persons who buy or sell for the short run on the basis of information, or evidence of the existence of information, that they believe 
ing their buying and selling in equities of issuers about which they and their advisers start with natural information advantages. ${ }^{24}$ These are likely to be domestic issuers because the futures of most issuers are determined more by "inside" forces - those occurring within the borders of their an issuer's own nation - than by forces occurring outside.

For several reasons residents of a given nation have advantages over foreigners in gaining specialized information about their nation's inside forces and are more familiar with the institutions involved in the process of price formation for their own nation's issuers. One reason is that the costs of acquiring bits of local information are lower for a resident. Residents are more likely to be able to read the language in which materials containing such information are published and to receive such materials promptly and cheaply. Also, the costs of such information-gathering tasks as telephone conversations, face-to-face conversations, and site visits are lower for residents. Thus it is far easier for a resident to gather more bits of local information at a reasonable expenditure.

More important, these same economies permit a resident who receives a large number of bits of such information to develop refined rules for evaluating them: to choose which bits to analyze seriously and by which to be influenced. ${ }^{25}$ This evaluation must be

will soon become more widely known and (ii) investors who purchase for the longer run on the basis of what they believe to be their superior analysis of the "fundamentals" - i.e., information concerning the underlying business of the issuer and its prospects.

24. This statement is not necessarily inconsistent with the efficient market hypothesis (EMH), which is another pillar of the modern approach to finance. The EMH, most broadly stated, holds that the market price of a security fully reflects all information available at the time in question. The seminal article reviewing the work to its date that formed the basis for the hypothesis is Eugene F. Fama, Efficient Capital Markets: A Review of Theory and Empirical Work, 25 J. FIN. 383 (1970). While one of the implications of the EMH is that the ordinary investor is wasting his time trying to pick "winners" on the basis of information he gleans from public sources, a subset of all investors encompasses persons who initially obtain new information and whose trades cause the price to reflect such new information. See Ronald J. Gilson \& Reinier H. Kraakman, The Mechanisms of Market Efficiency, 70 VA. L. REV. 549, 569-70 (1984). This subset may be responsible for a substantial percentage of all transactions. It should also be noted that the EMH is controversial and is less accepted with respect to "soft" information about issuers than it is with respect to hard data such as the announcement of a dividend increase. See Merritt B. Fox, The Role of the Market Model in Corporate Law Analysis: A Comment on Weiss and White, 76 CAL. L. REv. 1015, 1044 (1988); Gilson \& Kraakman, supra, at 561-62.

25 . The questions addressed here really apply to the processing of information by a whole network of persons - the participants in the finance process - whose decisions ultimately determine which real investment projects are implemented. The role played by these different participants - project proponents, firm managers, financial intermediaries, investment advisers, and individual investors - and the nature of the rules by which these participants process information are considered in more detail in MERRITT B. FOX, FINANCE AND INDUStrial Performance in a Dynamic Economy: Theory, Practice, and Policy 92-232 (1987). 
based both on the source of the information as well as on its content. The concern with source goes to the accuracy of the information. It asks how trustworthy the source is and, assuming the information has an interpretative element, how competent the source is. The concern with content asks how much the bit, assuming the information is accurate, tells the recipient about whether a particular security is underpriced or overpriced.

The resident recipient, through his education and his continuous absorption of general information concerning his nation, starts with a much richer context in which to make these evaluations. He can also obtain cheaply much more information concerning both the structure of the source's motivations and the reputation of the source. Because acquiring information from the source is generally less expensive for residents than nonresidents, the resident recipient is also more likely to have had prior personal experience with the source and hence has more feedback on the quality of information the source provides. ${ }^{26}$ The resident recipient is, for the same reasons, more likely to have had prior experience by which to assess the usefulness of information with any particular content when the information involved relates to local forces.

\section{Currency Exchange Risks}

If a resident of the United States purchases a security of an issuer of France, the investor must consider the possibility that when he converts the return back into dollars, the rate of exchange may be different than at the time of the purchase. Thus, to the U.S. investor, the French security has an additional element of risk - an additional source of variability of return - that would not be present with an otherwise identical U.S. security. ${ }^{27}$ Moreover, the size of many exchange rate fluctuations in recent years has been suffi-

26. For an example in the legal literature of the use of this kind of "reputation theory," see, e.g., Ronald J. Gilson \& Robert H. Mnookin, Coming of Age in a Corporate Law Firm: The Economics of Associate Career Patterns, 41 Stan. L. Rev. 567, 578-79 (1989).

27. Financial economists often assume away foreign currency exchange risk entirely, under the theory that it can be easily eliminated through hedging. See, e.g., Kang \& Stulz, supra note 22, at 9 . This is probably true for large institutional investors that, at a low cost per dollar invested in foreign shares, can engage in privately negotiated forward contracts and other hedging devices extending out over many years. It is not true, however, of the typical individual investor, who can only hedge by dealing in the currency futures market, where the maximum duration of available hedges is much shorter and transactions costs are significant. Even if individual investors have the alternative of investing in mutual funds specializing in foreign stocks that can hedge cheaply and over the long term due to their size and sophistication, the limitations on the hedging ability of individual investors can be a factor favoring segmented national markets, because some of them would rather invest on their own. 
cient to swamp the other factors that make the return on a security variable. ${ }^{28}$ The extent, however, to which the possibility of exchange rate fluctuations deters transnational security transactions depends on the effect of the fluctuations on the riskiness of the investor's whole portfolio, not on individual securities, and on the impact of portfolio riskiness on the individual's utility.

If, in our example of a U.S. investor, the rates of exchange of the dollar for the currency of each other nation vary independently of each other, the added riskiness of the individual foreign securities need not add anything to the riskiness of the investor's portfolio as a whole. With holdings of foreign securities from a diversified set of nations, the variations in return of individual securities caused by exchange rate fluctuations would tend to cancel each other out. For a U.S. investor, such exchange rate independence would be approximated in a situation where the exchange rate performance of the dollar, compared to other nations, was in some sense average - that is, the dollar's value was stable relative to a basket made up of the currencies of the other nations of the world.

Where foreign currencies move systematically vis-à-vis the investor's national currency, as has been the case with the dollar over the last fifteen years, exchange rate fluctuations do not cancel out each other in this fashion. Other factors, however, may nevertheless limit the effect of the resulting variation in portfolio return on the investor's utility. ${ }^{29}$ First, changes over time in currency exchange rates between two countries are heavily influenced by differences in the countries' relative rates of inflation. The direction of the influence tends to compensate for the effects of the respective rates of national inflation on the issuer's return measured in the issuer's national currency and on the investor's cost of consumption measured in his national currency.

With a U.S. investor and a French issuer, for example, a higher inflation rate in the United States than in France would mean that, ceteris paribus, the dollar cost of consumption in the United States would increase more as a result of inflation than would the French security's return as measured in francs. But the effect of the higher inflation in the United States on the dollar/franc exchange rate would be to weaken the dollar so that the investor would receive

28. For example, between January and June of 1995 , the dollar dropped $15.3 \%$ against the yen. See Strong Yen Steadily Contributing to Lower Domestic Prices, JAPAN ECON. NEwSWIRE Plus, Dec. 25, 1995, available in Westlaw, Dialog, Japanecon database.

29. The investor is assumed to choose the portfolio that will provide the investor with the highest expected utility from the consumption of the end-of-period invested wealth. See supra note 16. 
more dollars per franc. Consequently, his return on the security measured in dollars might well, as a result, keep up with the U.S. rate of inflation. Thus, in terms of the ultimate goal of investment - future consumption - exchange rate fluctuations may have a stabilizing rather than destabilizing effect. ${ }^{30}$

Another factor limiting the effect of variation in portfolio return caused by fluctuations in exchange rates on the investor's utility is the probability that part of what the investor is likely to consume is imported from abroad: in domestic currency terms, exchange rate fluctuation will affect the return on foreign securities and the cost of imported goods in the same direction. Since one is income and the other expenditure, the effects tend to compensate for each other.

Finally, to the extent that domestic issuers themselves make direct investments abroad, their returns too are affected by foreign exchange rate risk. As a consequence, there is less incentive to avoid securities of foreign issuers just to avoid foreign exchange risk. ${ }^{31}$

\section{Government Impediments to Transnational Investments}

In the case of a potential transaction involving an issuer or secondary seller of one nation and an investor of another, the government of either nation may have tax or currency exchange regulations that create sufficient disincentives that the transaction does not take place. ${ }^{32}$ The government of the investor, for exam-

30. The risk of inflation at home in goods and services that are available only from domestic (i.e., nontraded) sources may still be a residual source of home bias. Compared to investing in foreign equities, investing in domestic equities may be a better hedge against this risk, because the nominal returns on domestic equities may well correlate more closely with changes in the nominal prices of nontraded goods and services than do nominal returns on foreign equities, even after adjustment for changes in the exchange rate. This is because factors other than domestic inflation rates can substantially influence exchange rates and cause large deviations from the rates that would achieve purchasing power parity - i.e., rates where the same representative bundle of consumption goods costs the same in dollars - or any other currency - in every country. See Michael Adler \& Bernard Dumas, International Portfolio Choice and Corporation Finance: A Synthesis, 38 J. Fin. 925 (1983); Cooper \& Kaplanis, supra note 22, at 46-47. Cooper and Kaplanis, however, test empirically the proposition that this is an explanation of home bias and reject the hypothesis. See Cooper \& Kaplanis, supra note 22 , at $50-52$.

31. The existence of domestic issuers with direct foreign investment also weakens the incentive to diversify by investing in foreign securities. One empirical study, however, suggests that a diversified portfolio of U.S. multinational corporations does not achieve nearly as much risk reduction as does a portfolio of internationally diversified issuers. See Bertrand Jacquillat \& Bruno Solnik, Multinationals Are Poor Tools for Diversification, J. PORTFOLIO MgMt., Winter 1978, at 8.

32. These factors, if they do not render the transaction impossible, at the very least reduce the investor's expected return from undertaking the investment. Absent these factors, an investor in country $A$ would be able to enjoy the same rate of return from an investment in the stock of an issuer from country $B$ that investors in $B$ would enjoy. The investor from $A$ 
ple, may make it difficult or impossible to obtain the foreign currency with which to purchase the security, may tax the returns on foreign securities at a higher rate than it taxes the returns on domestic securities, ${ }^{33}$ or may refuse to grant the domestic holder of a foreign security a tax credit for taxes withheld from the returns by the government of the issuer. The government of the issuer may make it difficult or impossible for a foreign investor to turn returns paid in the local currency into the investor's domestic currency or impose a withholding tax on the returns that, for a number of possible reasons, may not reduce the investor's home tax obligations by a commensurate amount. ${ }^{34}$ Transnational transactions can be discouraged not only by currently existing regulations of these sorts but also by the fear that they might be imposed at some time in the future during the investor's period of ownership.

\section{Transaction Costs of Trading in Foreign Securities}

A final factor favoring national securities markets is the extra costs to the purchaser and to the issuer or secondary seller of entering into transactions occurring across national lines. These include the additional costs associated with international communications, currency exchange, and clearance and settlement - the physical

would therefore find attractive, for diversification reasons, an investment in the stock of a $B$ issuer that is priced to produce an expected return for investors in $B$ comparable to the expected return the investor in $A$ could earn on investments in the stocks of his own country's issuers. With these factors lowering the expected return available to the $A$ investor, however, diversification considerations may be insufficient to attract him to invest at all and will certainly induce him not to invest as much.

33. The United States Interest Equalization Tax Act, Pub. L. No. 88-563, 78 Stat. 841 (1964) (formerly codified at scattered sections of the I.R.C.; repealed 1974), which was in effect between 1963 and 1974, was an example of a tax provision intended to discourage investment in foreign securities by U.S. residents. The Act imposed a $15 \%$ tax on the purchase of such securities. The idea behind this tax-induced segmentation of the world's financial markets was to permit the United States to pursue a monetary policy of interest rates lower than those prevailing abroad without aggravating its balance of payments problems. See U.S. Sec. \& Exch. Commn., Report of the Staff of the U.S. Securities and Exchange Commission to the Senate Committee on Banking, Housing and Urban Affairs and the House Committee on Energy and Commerce on the Internationalization of the Securities Market III-14 to -15 \& n.21 (1987) [hereinafter 1987 SEC InTERnATIONALIZATION RePORT]; Robert L. Maines, Note, The Interest Equalization Tax, 17 Stan. L. Rev. 710 (1965).

34. Cooper and Kaplanis give as an example a U.K. pension fund, the income of which is tax exempt under U.K. tax law, but the U.S. income of which would be subject to a $15 \%$ U.S. withholding tax. Thus, for a dividend yield of $7 \%$, there would be a reduction in the return on investment down to approximately $6 \%$ when the fund chooses U.S. rather than U.K. equities. Cooper and Kaplanis question the relative importance of this factor, however. They argue that even after taking account of the extra expenses of foreign investing, it would take levels of risk aversion well above what is commonly believed to be that of the average investor for this to explain most of why U.K. investors invest such a small portion of their portfolios in foreign stocks. See Cooper \& Kaplanis, supra note 22, at 55-57; see also Kang \& Stulz, supra note 22 , at 7-8. 
delivery of the security in exchange for the payment of the purchase price. ${ }^{35}$ Some of these costs are not present where a foreign issuer is listed on a domestic exchange, but in that event the issuer faces extra costs. ${ }^{36}$

\section{The Current Extent of Globalization - The Price Dimension}

Economic forces exist that by themselves would lead to a truly global securities market. But as we have seen, these forces face counterforces favoring segmented national markets. Do these counterforces reduce the level of transnational transactions to the point where the price of an equity, whose future cash flows are determined by a given probability distribution, would vary based on the nationality of its issuer or of the exchange on which it is principally traded? In other words, are these counterforces still sufficiently strong to keep the "law of one price" from applying globally, or have they weakened to the point that we can say the market for securities is globally integrated?

\section{International Capital Asset Pricing Model Studies}

One way to test this question is to construct a plausible model for the pricing of risk in a global market for securities, patterned after the domestic capital asset pricing model (CAPM). ${ }^{37}$ The

35. Cooper and Kaplanis try to give a feel for the scale of this factor by noting a study that found the expense ratio for U.S. mutual funds specializing in foreign issuers was $0.68 \%$ per annum higher than for funds investing primarily in U.S. issuers. As noted above, this factor, combined with the impact of withholding taxes, is unlikely to explain most of the home bias of U.S. investors. See Cooper \& Kaplanis, supra note 22, at 56. For institutional investors, the $0.68 \%$ per annum figure probably overstates the extra transaction costs associated with investing in foreign equities, as it also would include the presumably larger research expenses associated with foreign investment. For individual investors who trade with any frequency, however, it probably considerably understates the impact of the extra transaction costs, as they do not enjoy the volume discounts available to institutional investors.

36. These extra issuer costs include a listing fee on the domestic exchange, maintenance of a transfer agent, and the costs of compliance with any applicable local securities laws.

37. The CAPM is a widely used model of the pricing in a domestic market of capital assets such as securities. The CAPM assumes, among other things, that (i) the "market portfolio" - a portfolio containing all available capital assets in the same proportions to each other as they are found in the market - is efficient; that is, it has the lowest variance of any available portfolio with its expected return; and (ii) all investors have identical beliefs concerning the probability distribution of future returns on the available assets. This second assumption can be used to prove the first. Because the market portfolio is efficient, it contains no diversifiable (unsystematic) risk, only systematic risk. Thus the systematic risk of any given asset can be measured by its covariance with the market portfolio. Because any portion of the risk of such asset that does not covary with the market portfolio can be diversified away, the only portion of the risk that investors will pay a premium to avoid is the portion that does covary. From this, it can be shown that each asset will be priced so that its expected return is a function of (i) the covariance between the asset's return and the return on the market portfolio, (ii) the rate of return on a "safe" asset, and (iii) the expected return on the market portfolio. See William F. Sharpe, Capital Asset Prices: A Theory of Market 
model can then be tested empirically to see how well it explains the pricing of securities around the world. If the model has strong empirical support, that would suggest that the law of one price does apply in the market for corporate equities, with the shares of all issuers, whatever their nationality, being priced, after adjustment for risk, to yield the same expected return. ${ }^{38}$ While some early

Equilibrium Under Conditions of Risk, 19 J. Fin. 425 (1964). A particularly accessible description of the model is found in LORIE ET AL., supra note 18, at 132-43.

The CAPM cannot be tested directly because expected returns are subjective, unobservable judgments of investors. It can be made empirically testable, however, by assuming that the market is a "fair game" - i.e., on average the actual return on an asset equals its expected return. If this is the case, data on past actual returns can provide information about past expected returns. Returns on the market portfolio are measured by a market index that is composed of a set of securities that is assumed to be a representative proxy for the market portfolio. The existing empirical tests of the CAPM have, however, been subjected to some important criticisms. See Eugene F. Fama \& Kenneth R. French, The Cross-Section of Expected Stock Returns, 47 J. Fin. 427 (1992); Jeffrey N. Gordon \& Lewis A. Kornhauser, Efficient Markets, Costly Information, and Securities Research, 60 N.Y.U. L. REv. 761, 775-86 (1985); Richard Roll, A Critique of the Asset Pricing Theory's Tests - Part I: On Past and Potential Testability of the Theory, 4 J. FIN. ECON. 129 (1977). Nonetheless, the wide use of the CAPM by finance economists suggests that a large portion of them view the tests as showing that it has significant power to explain securities pricing. See Ronald J. Gilson \& Bernard S. Black, The law and Finance of Corporate Acouisitions 101 (2d ed. 1995).

38. The basic approach is to construct a model of what securities pricing in an integrated global market would look like and then to test the model to see if the experience in the real world conforms. The seminal work in this area was performed by Solnik, on the international asset pricing model (IAPM), which resembles the CAPM but is modified to take account of the possibility of international diversification and the effect that it might have on the pricing of assets. See B.H. Solnik, The International Pricing of Risk: An Empirical Investigation of the World Capital Market Structure, 29 J. Fin. 365 (1974). The CAPM cannot be applied without such modification because the returns of different securities are denominated in different currencies. This creates exchange risk for each investor when she invests in any security other than risky securities of her own nation or its "safe" asset - that is, an asset with a payoff known for certain, denominated in his nation's currency. The solution is to separate the risk of each security as denominated in its local currency and the exchange rate risk it poses for foreign investors by assuming that each investor behaves as if she purchases a world market portfolio when: (i) she hedges each purchase of a foreign security by borrowing in the local currency or purchasing an exchange rate future and (ii) she invests as well in a pure exchange risk portfolio consisting of a weighted average of the safe assets of each country in proportion to its net foreign investment position. From this, it can be shown that each security of a given nation will be priced so that its expected return is a function of (i) the covariance between the security's return and the return on the world market portfolio, (ii) the expected return on the world market portfolio, (iii) the rate of return on that nation's safe asset, and (iv) the weighted average of the rates on the returns of the safe assets of all nations. See id. at $368-69$.

Solnik's tests of the IAPM purport to show that a security's covariance with his index for the world market portfolio - his measure of the security's international risk - has significant power explaining the prices of each nation's securities. See id. at $372-73$ \& tbl.3; see also Bruno H. Solnik, An International Market Model of Security Price Behavior, 9 J. FIN. \& Quantitative ANalysis 537, 552 (1974) [hereinafter Solnik, International Market Model]. From this, he concludes that the "international capital market seems to be sufficiently integrated and efficient to induce an international pricing of risk for common stocks." Id. at 553. Adler and Dumas concluded in a later survey article that the tests of the IAPM, including Solnik's, have been "inconclusive ... from a statistical standpoint." Adler \& Dumas, supra note 30 , at 954 . Stehle focuses more directly on the segmentation versus integration issue by testing the hypothesis that the U.S. market is totally segmented against the null hypothesis 
studies appeared to provide empirical support for such models, ${ }^{39}$ more recent work suggests that this support is at best weak. ${ }^{40}$

What inferences concerning global integration can be drawn from this? One explanation for the low level of empirical support is that the market is, in fact, not globally integrated. Another is that the market is globally integrated, but that the tested models do not correctly describe the pricing of risk and so apparent differences among countries in terms of the risk-adjusted expected returns of their issuers' equities are simply the result of errors in the risk adjustments. Alternatively, the market, while integrated, may not be efficient. Equities of particular countries may be systematically traded at prices deviating from their fundamental values because of "noise traders" influenced by "fads" or "fashions" concerning these countries. ${ }^{41}$

that it is completely integrated with the rest of the world and by testing the reverse set of hypotheses. See Richard Stehle, An Empirical Test of the Alternative Hypotheses of National and International Pricing of Risky Assets, 32 J. Fin. 493 (1977). He was unable, however, to reject either theory in favor of the other. See id. at 501. Expressing various methodological concerns, Solnik himself joined this more skeptical view in a later article. See Bruno H. Solnik, Testing International Asset Pricing: Some Pessimistic Views, 32 J. Fin. 503 (1977).

The IAPM has been subject as well to more basic theoretical criticisms that are relevant to its utility as a method of determining the degree of segmentation in the market for securities. The most important problem is that the price of consuming a given good or service in one country differs from the price, translated at existing exchange rates, of consuming the same good or service in another country. Because the criteria by which an investor chooses her portfolio is the maximization of her expected utility from future consumption, an investor in one country will use a different yardstick to measure the real return to her of a security than will an investor in another country. Hence a different portfolio will be optimal for each, and there is no single optimal world market portfolio for all investors. This problem is compounded by the fact that consumption preferences vary among investors of different countries so that they want to consume different bundles of goods. These kinds of problems led Adler and Dumas to conclude that "there is as yet no definitive empirical method for determining whether and to what extent the international capital market is segmented." Adler \& Dumas, supra note 30, at 967; see also René M. Stulz, Pricing Capital Assets in an International Setting: An Introduction, J. INTL. Bus. Stud., Winter 1984, at 55.

\section{See supra note 38 .}

40. In a recent survey of the literature, Jeffrey Frankel states: "We have seen that the tests, even those that make full allowance for the range of international assets to be held and the range of countries where investors live, seem consistently to reject the international CAPM hypothesis." Jeffrey A. Frankel, Introduction to THE INTERNATIONALIZATION OF EQUITY MARKETs 1, 12 (Jeffrey A. Frankel ed., 1994). Similarly, Froot and Dabora state: "There is a large literature that finds evidence of international segmentation. Risk return tradeoffs, as measured by a pricing model such as the international CAPM, appear to differ in some countries." Kenneth A. Froot \& Emil Dabora, How Are Stock Prices Affected by the Location of Trade? 2 (Dec. 8, 1995) (unpublished paper, presented at NYSE Palm Beach Conference); see also Vihang Errunza \& Etienne Losque, International Asset Pricing Under Mild Segmentation: Theory and Test, 40 J. Fin. 105, 121 (1985); Campbell R. Harvey, The World Price of Covariance Risk, 46 J. Fin. 111, 147 (1991).

41. See infra note 76. The first and third explanations may amount largely to the same thing, because each implies that a project's cost of capital would differ depending on the primary trading place for the shares of the issuer considering the project. 


\section{Studies of Securities Sharing the Same Underlying Cash Flows}

Another approach to determining whether the market is globally integrated is to find securities trading in different markets that share the same underlying cash flows and test whether they are priced to produce the same expected return. This avoids the tricky problem of modeling the price of risk that is necessary when cash flows with different risk characteristics are compared.

One example of securities sharing the same underlying cash flows involves closed-end country funds. These are investment companies whose shares are traded on a major developed country exchange such as the New York Stock Exchange and whose assets consist solely of shares of issuers of some other country. Thus two sets of securities - a share of a country fund and a bundle of individual shares identical to what the fund holds as assets - share the same underlying future cash flow. Studies show, however, that the typical fund's share price deviates, often substantially, from the price of the bundle of individual shares that make up its assets. The direction and extent of this deviation is significantly influenced by what is happening in the market on which the fund shares are traded. ${ }^{42}$

Another example is "Siamese twin" stocks, which are stocks of companies whose charters fix proportionally the division of a common pool of current and future equity cash flows, with both twins traded on the same two developed country markets but with one traded more actively on one market and the other more actively on the other. In an efficient integrated market, we would expect their prices to move in lockstep, particularly because both securities are traded in both markets so that the transaction costs of arbitrage between them are low. Such pricing studies, however, also find large deviations that are "highly correlated with the relative stockmarket indexes of the country where each stock is traded most actively." 43

The price deviation in each example suggests either a lack of global integration or lack of market efficiency based on fads and fashions related to local markets. But in each example the devia-

42. See James N. Bodurtha, Jr., et al., Closed-End Country Funds and U.S. Market Sentiment, 8 Rev. Fin. Stud. 879 (1995); Gikas A. Hardouvelis et al., What Moves the Discount ON COUNTRY EOUITY Funds? (National Bureau of Economic Research Working Paper No. 4571, 1993).

43. Froot \& Dabora, supra note 40, at 3; see also Leonard Rosenthal \& Colin Young, The Seemingly Anomalous Price Behavior of Royal Dutch/Shell and Unilever N.V./PLC, 26 J. Fin. ECON. 123 (1990) (finding large deviations in the pricing of the twin companies' stocks). 
tion is open to an alternative explanation that is consistent with a globally integrated, efficient market for equities. For the closedend country funds, the market for the underlying stocks may be sufficiently nonliquid and inaccessible as to create very large arbitrage costs. ${ }^{44}$ For the Siamese twin stocks, there may be taxinduced differences in the composition of each firm's shareholder group, with the kind of investors interested in each having different reservation prices for the stock. ${ }^{45}$

\section{Conclusion}

Empirical work to date has provided no clear assessment of the extent to which today's equities market is globally integrated. Some sense of the predominant opinion among financial economists, however, can be gleaned from the standard texts in the field. These suggest that some sets of countries already have relatively highly integrated markets for securities - for example, the United States and Canada, or the Benelux countries. Most others are less integrated but are moving in that direction. ${ }^{46}$ We will see that my conclusions concerning the appropriate apportionment of regulatory authority will hold whether the market for corporate equities is fully integrated along the price dimension or not, but the reasoning used to get there differs at some points in the argument.

\section{The Current Extent of Globalization - The Pattern of Holdings Dimension}

The counterforces favoring segmentation clearly continue to have a strong negative effect on globalization as measured along the investor holdings dimension. Absent the continued existence of these factors, transnational transactions would be of much greater

44. See Froot \& Dabora, supra note 40 , at 2.

45. See id. at 15-17 (asserting that the Siamese twin stock deviations results are best explained by the market for equities being segmented and inefficient but that tax-induced investor heterogeneity is the most likely alternative explanation).

46. See Edwin J. Elton \& Martin J. Gruber, Modern Portfolio Theory and InVESTMENT ANALYSIS 272-74 (5th ed. 1995). Another commentator states that "[t]he evidence suggests that world security markets are [at least partially] integrated ... [and t]o the extent there is some segmentation the corporation may be able to do something for its stockholders that they cannot do for themselves, namely, reduce risk through direct foreign investments." James C. Van Horne, Financial Management and Policy 715 (10th ed. 1995). Still another commentator reviews one study as having "found some evidence that markets are integrated" and another as having "also found weak evidence in support of integration." Thomas E. Copeland \& J. Fred Weston, Financial Theory and Corporate Policy 811 (3d ed. 1988) (citing F.L.A. Grauer et al., Sharing Rules and Equilibrium in an International Capital Market Under Uncertainty, 3 J. Fin. ECON. 233 (1976); Solnik, International Market Model, supra note 38). 
importance than they are. The correlations between indices representing the equity markets of different countries are remarkably low and generally well below the average correlation coefficient between a pair of United States securities. ${ }^{47}$ This suggests that a large amount of risk reduction is possible from international diversification beyond what can be accomplished by diversification among the issuers of a single nationality. For example, Solnik showed that the average variability - including the exchange risk to a U.S. investor - of return for a set of portfolios, each of which consisted of equal investments in fifty securities chosen randomly from a list of European and U.S. securities, was less than half of the average variability of a set of portfolios composed on the same basis but from a list restricted to U.S. issuers. ${ }^{48}$ Turning the risk/return tradeoff around the other way, French and Poterba show, for example, that to justify as rational current patterns of holdings, given their foregone diversification opportunities, U.S. investors must believe that U.S. issuers have expected returns $2.5 \%$ higher than Japanese issuers have and Japanese investors must believe that U.S. issuers have expected returns $3.5 \%$ lower than Japanese issuers have. ${ }^{49}$ One set of investors has to be wrong; quite possibly both are. If it is one set, they are missing out on transnational investments that would both significantly add to portfolio expected return and significantly reduce portfolio risk; if it is both, they are missing out on transnational investments that could significantly reduce risk while maintaining expected return.

These data suggest that if U.S. investors believe that the average rate of return on U.S. and non-U.S. equities is the same, they should, in the absence of factors favoring national markets, hold U.S. and non-U.S. equities in approximately the same proportions to each other as the proportions of U.S. and non-U.S. equities in the total market value of all equities available in the world. The same suggestion would apply to non-U.S. investors. ${ }^{50}$

47. See Elton \& GRUBer, supra note 46, at 274.

48. See Bruno H. Solnik, Why Not Diversify Internationally Rather Than Domestically?, Fin. ANALYSTS J., July-Aug. 1974, at 48, 51 fig.11. The gains in risk reduction from international diversification presumably would have been even greater if Japanese and Latin American securities had been included. See id. at 52 .

49. See French \& Poterba, supra note 12, at 223.

50. Putting aside for a moment differential pricing depending on the tendencies of securities of different countries to contribute to the riskiness of a diversified portfolio (as predicted by the CAPM and IAPM), one would expect that if investors worldwide share identical expectations, equities would be priced so that they all have the same expected return and investors of any one nation would have no reason to choose domestic over foreign securities. There is, of course, the possibility that the market is not well described by the assumption that investors in different countries share the same beliefs concerning the future returns of 
The extent of international diversification by both U.S. investors and non-U.S. investors falls far short of this crude prediction of what would prevail without counterfactors favoring national markets. For example, in 1993, the U.S. and non-U.S. markets represented, respectively, $37 \%$ and $63 \%$ of the total market value of all publicly traded equities available in the world. However, U.S. investors on average held only $5.7 \%$ of their equity portfolios in nonU.S. issuer stock, the remaining $94.3 \%$ being devoted to U.S. issuers. The portfolio imbalance was similarly reflected in non-U.S. investor holdings, which consisted of $97 \%$ non-U.S. issuer stocks and $3 \%$ U.S. issuer stocks. ${ }^{51}$

These data show that the counterfactors favoring national markets continue to restrain the level of transnational transactions sufficiently that the market for corporate equities still falls far short of being "truly global" in terms of the pattern of holdings dimension. But they also show the potential for a vast increase in the volume of such transactions. If, as predicted in the next Section, these counterfactors weaken significantly, transnational transactions will in the future constitute a much larger portion of all transactions, perhaps five or ten times greater than today.

any given security, which, as developed below, may help explain why transnational transactions are not more prevalent. To the extent that pricing does depend on systematic risk, the conclusion in the text still holds, because in such a market any investor that does not fully diversify will be taking on uncompensated risk.

51. All percentages are derived from the following data for calendar year 1993:

\begin{tabular}{|c|c|c|c|}
\hline & U.S. issuer equity & Non-U.S. issuer equity & Total \\
\hline $\begin{array}{l}\text { equity market } \\
\text { capitalization }\end{array}$ & $\$ 5.2$ trillion $(37 \%)$ & $\$ 8.9$ trillion $(63 \%)$ & 14.1 trillion \\
\hline $\begin{array}{l}\text { holdings by } \\
\text { U.S. investors }\end{array}$ & $\$ 4.9$ trillion $(94 \%)$ & $\$ .3$ trillion $(6 \%)$ & 5.2 trillion \\
\hline oldings by non- & $\$ .3$ trillion $(3 \%)$ & $\$ 8.6$ trillion $(97 \%)$ & 8.9 trillion \\
\hline
\end{tabular}
U.S. investors

Figures in the above table come from the following sources: U.S. SEC. \& ExCH. COMMN., 1994 ANNUAL REPORT 28 (1994) (reporting that U.S. equity market capitalization in 1993 equalled $\$ 5.2$ trillion and reporting that worldwide equity market capitalization in 1993 was $\$ 14.1$ trillion, allowing a calculation of non-U.S. equity market capitalization as $\$ 14.1$ trillion minus \$5.2 trillion); Russell B. Scholl, The International Investment Position of the United States in 1994, Surv. Current Bus., June 1995, at 52, 56 (reporting holdings by non-U.S. investors of U.S. equity securities in 1993 of $\$ 340.0$ billion); id. at 54 (reporting holdings by U.S. investors of non-U.S. equity securities in 1993 of $\$ 297.7$ billion). Thus, based on the foregoing figures, holdings by U.S. investors of U.S. equity securities in 1993 equalled $\$ 5.2$ trillion minus $\$ 340$ billion, or $\$ 4.9$ trillion; holdings by non-U.S. investors of non-U.S. equity securities equalled $\$ 8.9$ trillion minus $\$ 297.7$ billion, or $\$ 8.6$ trillion. 


\section{E. The Future of the Factors Favoring National Markets}

\section{Information}

Until recently, U.S. investors, including sophisticated institutional investors, held very few foreign equities in their portfolios. ${ }^{52}$ Because this would be hard to explain solely as the result of the other counterfactors favoring national markets, the information advantages that investors of a given nation have concerning the prospects of that nation's issuers must have played a substantial role in explaining why international diversification has historically been so limited. ${ }^{53}$ Conventional theories of investment behavior for both speculators and passive investors would not, however, have predicted this reluctance to invest in foreign securities.

In conventional theory, the speculator in the domestic market designs his portfolio on the basis of his own beliefs, formed by the information in his possession, concerning the probability distributions of the future returns of the available securities. The fact that

52. See Elton \& Gruber, supra note 47, at 262. Although these authors do not mention them, casual empiricism and the SEC rules both suggest that Canadian securities have been an exception to the historical tendency of U.S. investors to shun foreign equities. This fact tends to support the information explanation for home bias, because U.S. investors know more about Canadian issuers than any others, but Canadian securities are the least desirable foreign security from the diversification point of view. Canadian share prices are far more highly correlated with United States share prices than the share prices of any other nation. See Elton \& Gruber, supra note 46, at 267 tbl.12.3.

As recently as 1979 , only eight percent of the 1600 largest U.S. pension funds, despite their sophistication, invested any money at all in foreign stocks. See Marcia Berss, Tomorrow the World, Forbes, July 2, 1984, at 104,107 . In 1983 , pension funds invested only $\$ 8.7$ billion in foreign securities, see id., a tiny portion of the $\$ 981.1$ billion then entrusted to them, see Steven Greenhouse, Just Whose Money Is in an Employee Pension Plan?, N.Y. Times, Feb. 1, $1987, \S 4$, at 7. By 1991 the top 200 pension funds alone invested $\$ 68$ billion in foreign markets. See Margaret Price, International Assets See Healthy Increase, CRAIN's Pensions \& INV., Jan. 20, 1992, at 17 . Also by then, over 400 mutual funds, with assets of about $\$ 80$ billion, invested almost exclusively in foreign securities. See Remarks of Richard Breeden, Chairman of the SEC, to the Investment Company Institute General Membership Meeting, Wash., D.C. (May 21, 1992), available in LEXIS, News Library, Fednew file.

53. An extensive literature relating to home bias discussed in prior notes supports this conclusion. See supra notes $22,27,32,35$ and accompanying text. The point is also well illustrated by an example developed by Lessard. He calculated, assuming the expected return on United States equities is $15 \%$, the minimum expected return of a security from each of a variety of foreign countries that could still, because of its capacity to reduce portfolio risk, justify inclusion in the portfolio of a U.S. investor. For a substantial majority, the expected return can be less than $10 \%$ and still justify inclusion. These figures were based on the covariance between each nation's securities and a world index (a statistical measure of the extent to which the two moved together), all translated to dollars so that exchange risk is already considered. See Donald Lessard, World, Country, and Industry Relationships in equity Returns: Implications for Risk Reduction Through International Diversification, 32 FIN. ANAlysts J. 32 (1976); see also Elton \& GRUBER, supra note 46, at 277 tbl.12.10. It is highly unlikely that, for every one of these major developed nations, the existence, or fear of, differential taxes and exchange controls and the extra transaction costs of transnational transactions together would be sufficient to constitute the equivalent of a burden of more than five percent in rate-of-return terms. 
he is not fully informed about a given security causes him to assign a variance to his prediction of the future return, and the less he thinks he knows, the larger the variance. He assumes, however, that his prediction is unbiased - i.e., on average neither high nor low. A greater variance does not lead him to keep the security out of his portfolio.

The passive investor in the domestic market is unconcerned with his ignorance and buys securities because it is a way to store his savings that historically has produced, on average, a positive rate of return. He chooses a random selection of available securities assuming that the market price is the best estimate of the future return of each of the securities selected and that the portfolio's diversity will give him the maximum possible protection from risk.

The historical, near-total unwillingness of U.S. investors of both types to buy foreign equities suggests that their sense of greater ignorance about these issuers compared to domestic issuers has had a radical effect. The speculator must have felt that he did not know enough to make sensible evaluations of the probability distributions of their future returns. ${ }^{54}$ The passive investor must have felt that he did not know enough to trust the process by which foreign equities were priced. 55

The recent increase in ownership of foreign equities by U.S. investors suggests that this barrier - the unwillingness by most inves-

54. Ruth Mack, who has developed a general model of decisionmaking under uncertainty, suggests that human beings have an intolerance, which ex post appears irrational, for actions involving "ambiguity" - i.e., actions the riskiness of which is hard to evaluate. See RUth P. Mack, Planning on UnCertainty 55-58 (1971). The process by which investors evaluate the risks associated with investment in domestic equities is well established. See supra notes 16-17 and accompanying text. In comparison, a general lack of experience in evaluating the risks associated with foreign equities may lead to ambiguity-caused intolerance. Similarly, Heath and Tversky ran an experiment in which they found that subjects, faced with two gambles to which they assigned identical probability distributions, behaved as though the less familiar gamble was riskier. See Chip Heath \& Amos Tversky, Preference and Belief: Ambiguity and Competence in Choice Under Uncertainty, 4 J. RISK \& UNCERTAINTY 5 (1991). French \& Poterba cite this study and suggest that home bias may be explained in part by investors treating foreign stocks in the same way. See French \& Poterba, supra note 12, at 225 n.4. See generally Amos Tversky \& Daniel Kahneman, Rational Choice and the Framing of Decisions, 59 J. Bus. S251 (1986).

55. Going back further in history, there is precedent within the borders of the United States for this same kind of reluctance to invest outside a local market. Lance Davis concluded that until about 1914 a national capital market, even in large bank deposits, did not exist. Prior to that date, he found major differences in the interest rates offered by the major city banks in different regions of the country. These rate differences exceeded what could be accounted for in the default risk differences. This suggests that savers in low interest rate regions felt sufficiently ignorant about the banks in the high interest rate regions so as not to trust their savings to them and that there did not exist well-informed intermediaries with sufficient trustworthiness to obtain the amount of capital necessary to arbitrage the difference away. See Lance E. Davis, The Investment Market, 1870-1914: The Evolution of a National Market, 25 J. ECON. Hist. 355 (1965). 
tors even to consider their purchase - has been broken. Yet, the information advantages possessed by such investors with respect to domestic issuers probably still explains much of why investors are not nearly as diversified internationally as they would be if the market were truly global as measured by the pattern of holdings dimension. The asset pricing models, from which this projection of high diversification arises, create an image of a market entirely populated by passive investors who select random portfolios. The speculators - the participants responsible for the process by which prices are set and adjusted as new information reaches the market - are not considered. Yet speculators appear to hold a substantial portion of all outstanding equities. For example, institutional investors, most of which engage in at least some management of their portfolios, hold almost fifty percent of such securities. ${ }^{56}$ A large portion of individual investors, the holders of the remaining fifty percent, do not have well-diversified portfolios, ${ }^{57}$ suggesting that at least some are "playing the market," whether it makes sense for them to do so or not. Speculators, as noted earlier, are likely to do better concentrating their buying and selling in equities of issuers about which they start with a natural information advantage. In large measure, this is still domestic issuers.

In the future, however, technological change is likely to narrow substantially the differences in the respective costs of timely acquisition of information from foreign and domestic sources by telephone calls, links to computerized databases, electronic document transmission, and travel to engage in face-to-face meetings and onsite inspections. This is true both of information directly relevant to predicting the prospects of issuers and information about the motivations and reputation of the sources of the directly relevant information. These same technological changes, through their effect on mass media, marketing, education, scholarly research, and direct personal interaction, are working toward creating a more uniform social and economic culture among the developed nations of the world. This greater uniformity will assist the investor in evaluating the information he receives. Moreover, the rules by which investors and their advisers evaluate information have a "learning by doing"

56. See Financial Assets and Equity Holdings, Brancanto ReP., Jan. 1995, at 42 tbl.11.

57. See Marshall E. Blume \& Irwin Friend, The Changing Role of the IndividuAl Investor 46-50, 117-20 (1978); Marshall E. Blume \& Irwin Friend, The Asset Structure of Individual Portfolios and Some Implications for Utility Functions, 30 J. FIN. 585 (1975). 
aspect and improve with experience, ${ }^{58}$ so that even the decline in information costs to date has not yet had its full impact.

In addition, the technological changes that have already significantly narrowed information cost differences have been accompanied by the emergence of truly international securities houses backed by large amounts of capital. ${ }^{59}$ This development permits a very efficient transfer of information across national lines. Because the sender and the receiver of information are members of the same organization, the receiver has an unusually high degree of trust in, and experience with, the sender. They can employ wellrecognized symbols that incorporate a great deal of information. Again, the learning-by-doing aspect of this form of communication means that the full impact of this development has probably not yet been felt.

\section{Exchange Rates}

The recent increase in the importance of transnational transactions has occurred despite the likely inhibiting concurrent increase in the instability of exchange rates over the past twenty years, particularly the sharp increase followed by the sharp decrease in the value of the dollar against other major currencies in the $1980 \mathrm{~s} .{ }^{60}$ In recent years, however, fluctuations among the major currencies seem to have decreased, ${ }^{61}$ perhaps due to increased efforts by the world's monetary authorities to coordinate their actions so as to reduce instability. ${ }^{62}$ If these efforts are perceived as succeeding and investors feel less inhibited by exchange rate concerns, transnational transactions will be encouraged. The inhibiting effects of exchange rate concerns will be further softened if there is a continued

58. See supra notes 25-26 and accompanying text.

59. For example, in mid-1995 Merrill Lynch acquired London's largest stockbroker, Smith New Court, for $\$ 842$ million in cash. The merger created the largest securities firm in the world. See Helen Dunne, Merrill in £530m Cash Offer for Smith Deal With US Broker Creates World's Largest Securities Organisation, DaILy TelegraPH (London), July 22, 1995, City, at 1; Peter Truell, Merrill Lynch Buying Big British Securities Firm, N.Y. Times, July 22, 1995, at 33; Deal Would Form Biggest Brokerage, L.A. Times, July 22, 1995, at D2.

60. See Economic Report of the President, at 400, tbl.B-106 (1996).

61. Recently there has been a renewed interest and emphasis by the G7 countries in reducing currency fluctuations. See Forex, EuRomoney, Mar. 1996 (1996 Guide to Switzerland Supp.), available in LEXIS, News Library, Mags File; G7 Optimistic on World Economy Despite Slowdown, Reuters Fin. SERvice, June 16,1995, available in LEXIS, News Library, Non-US File; Santer Calls for Move to Stabilise Dollar, Agence France Presse, June 15, 1995, Financial Pages, available in LEXIS, News Library, Non-US File.

62. See C. Randall Henning, Europe's Monetary Union and the United States, ForeIGN Poly., Spring 1996, at 83; Leonard Silk, World System Seeks Stability, N.Y. TimEs, Nov. 13, 1987, at D2; cf. Leonard Silk, Is 'Conventional Wisdom' Wise?, N.Y. Times, Mar. 11, 1989, at D2 (noting that floating exchange rates have not provided predicted stability). 
increase in foreign trade. ${ }^{63}$ As we have seen, the effects of exchange rate fluctuations on the cost of consuming imported goods and on the returns on foreign investment tend to compensate for each other.

\section{Government Impediments}

The period between World War II and the early 1970s witnessed a variety of currency control and tax measures that tended to reinforce segmentation of markets along national lines. ${ }^{64}$ These measures have been largely dismantled in the last 15 years. ${ }^{65}$ While a return of such measures is conceivable, it is unlikely. The international finance genie is too much "out of the bottle." National economies have become structured on the expectation of a continued flow of international finance. Nations compete with one another to provide environments congenial to the financial services industry, which regards such taxes and regulations as an anathema. ${ }^{66}$ The further back in history tax and currency control measures become with the passage of time, the less will be the fear of their reimposition and the inhibiting effect of that fear on transnational investment.

\section{Transaction Costs}

The same technological changes that narrow the cost differential of obtaining information from foreign and from domestic sources

63. Total U.S. exports and imports of goods in 1965 equalled $9.4 \%$ of Gross National Product (GNP), while the comparable total in 1994 equalled $22.2 \%$ of GNP. See EcoNOMIC REPORT OF THE PRESIDENT, supra note 60, at 280-81 tbl.B-1.

64. At the end of World War II, the U.S. dollar was the only major currency that was freely convertible. It was not until 1958 that the major European currencies achieved full convertibility. See Richard Myrus, From Bretton Woods to Brussels: A Legal Analysis of the Exchange-Rate Arrangements of the International Monetary Fund and the European Community, 62 FORdHAM L. Rev. 2095, 2098 n.24 (1994).

65. See, e.g., Mark A. Sargent, A Future for Blue Sky Law, 62 U. Cin. L. Rev. 471, 489 (1993) (arguing that the elimination of currency exchange controls has been a dominant force behind the creation of a global securities market).

66. The Interest Equalization Tax imposed by the United States between 1963 and 1974, see supra note 33, is an example of the kind of damage that such taxes and regulations can do to a nation's financial services industry. The tax is generally believed to be a major cause of the development abroad of the Eurobond market and of the rebirth, at the expense of New York City, of London as an international financial center. See Hugh Stephenson, Shadow Over Banks in London: American Phaseout of Curbs May Hurt, N.Y. Times, Feb. 25, 1973, $\S 3$, at 6 . In contrast, deregulation of restrictions on foreign ownership of securities firms participating in the Tokyo and London stock markets contributed to the large growth of these markets in the years immediately following deregulation. See Martin French \& Peter Lee, World Equity Flows into London, Euromoney, Apr. 1987, at 54; Big Bang Brief, EconOMIST, Aug. 2, 1986, at 60; Japanese Give Foreign Brokers More Than They Bargained For, ECONOMIST, May 17, 1986, at 85. 
will greatly reduce differences in real costs between executing a purchase or sale on a foreign exchange versus on a domestic exchange, as it becomes practical for the major exchanges around the world to compete for listings and orders. In the event that computerized electronic trading of securities worldwide replaces trading on organized stock exchanges, differences in the cost of executing transactions in the shares of domestic and foreign issuers would totally disappear. ${ }^{67}$

\section{F. Conclusion}

The foregoing survey suggests that, at least if we put aside any possible segmenting effects of national securities laws, there are strong underlying forces at work that, over the next decade or two, will greatly increase the percentage of foreign ownership of most sizable corporations around the world and create a severalfold increase in the relative importance of transnational securities transactions. The prospect of this fundamental change underlies all of the discussion that follows.

67. Whether this current exchange-based structure of secondary trading will continue into the foreseeable future or there will be a move to electronic trading is a matter of debate. Exchange trading and computer trading are each institutions that centralize order flow. Computer trading has a number of advantages: easy investor access from anywhere through computers with real-time displays of bids, offers, and volume; low cost of operation; and ease of transaction reconstruction leading to more reliable clearance and settlement and more effective enforcement of regulations. A number of observers predict that computer trading will probably, or at least possibly, replace exchange trading. See JosEPH A. GRUNDFEST, INTERNATIONALIZATION OF THE WORLD'S SECURITIES MaRKETS: ECONOMIC CaUSES AND Regulatory Consequences - OR - Beware the Über-Regulator 19-20 (John M. Olin Program in Law \& Econ., Stanford Law Sch., Working Paper No. 68, Aug. 1990); Morris Mendelson \& Junius W. Peake, Electronic Execution Systems: Myth vs. Reality (U. Penn. Law and Economics Discussion Paper, Apr. 1990); Therese H. Maynard, What Is an "Exchange?" - Proprietary Electronic Securities Trading Systems and the Statutory Definition of an Exchange, 49 WASH. \& LEE L. REv. 833, 862 (1992).

The key question is whether a computer trading system can provide liquidity comparable to that provided by a system based on specialists operating on an exchange floor. See William C. Freund, Electronic Trading and Linkages in International Equity Markets, Fin. ANALYSTS J., May-June 1989, at 10, 12; Lewis D. Solomon \& Louise Corso, The Impact of Technology on the Trading of Securities: The Emerging Global Market and the Implications for Regulation, 24 J. Marshall L. Rev. 299, 318-19 (1991). There are real questions as to whether specialists in fact provide such liquidity, however, as their obligation to do so is vague and the capital at their disposal is small compared to the largest traders. See Jonathan Macey \& Hideki Kanda, The Stock Exchange as a Firm: The Emergence of Close Substitutes for the New York and Tokyo Exchanges, 75 Cornell L. Rev. 1007, 1026-34 (1990). Macey and Kanda point out that the Tokyo Stock Exchange essentially works without specialists who attempt to provide liquidity as the saitori firms, the ones that most resemble specialists, act as pure conduits that match buy orders and sell orders and are not allowed to trade on their own account in the stocks assigned to them. See id. at 1043-44. Macey and Kanda speculate that the functions that the saitori firms do provide could be done largely by computer. See id. at 1046. 
The large increase in transnational transactions, with their potential for triggering imposition of the disclosure regimes of multiple countries on a single issuer, will make the question of the apportionment of regulatory authority more critical. Increased globalization will also be seen as the key factor undermining the long-run viability both of the existing traditional U.S. approach to the reach of its disclosure scheme, with its emphasis on "investor protection," and of the recent SEC proposal to shift that emphasis to "market protection." These problems are likely to force a fundamental reassessment of the proper function of mandatory disclosure.

\section{The Benefits and Costs of Greater Disclosure}

The central purpose of this article is to determine which country or countries associated with a transnational share transaction should have the authority to require the issuer to reveal more about itself than it would voluntarily. In order to make this determination, we need to consider why anyone would care about the issuer's disclosure practices: What as a general matter are the benefits and costs of the issuer revealing more about itself? We then need to know how are these benefits and costs of issuer disclosure distributed among the multiple countries associated with the transaction. These are critical questions, because we cannot determine which country or countries can best weigh these costs and benefits without knowing the stakes of those doing the weighing.

This Part starts the analysis by looking at a single closed economy and considering the overall benefits and costs of greater issuer disclosure. This single closed economy can be thought of as the national economy of the past, when corporations invested primarily in their home country and there were relatively few transnational securities transactions - the kind of economy with which national regulations were originally designed to deal. It can alternatively be thought of as the likely global economy of the long-term future when there will be a single highly integrated market for securities, in which issuers responsible for a large portion of the world's production will have their operations dispersed around the world, showing no national pattern of concentration, and decisions concerning mandatory disclosure will be made by a single global authority.

We will assume throughout this article that all issuers are subject to a basic antifraud rule that prohibits the making of materially false statements and of omissions that make the statements made 
misleading. There is a great deal of information, however, that issuers subject only to an antifraud rule would choose not to make public. That, of course, is why systems of mandatory disclosure regulation developed in the first place.

\section{A. Benefits of Greater Disclosure}

Three kinds of rationales can be put forward for forcing issuers to disclose any given kind of information, suggesting three possible benefits from greater disclosure: (1) the market will be a fairer place in which to invest; (2) the market will be a less risky place to invest; and (3) resources will be allocated more efficiently. ${ }^{68}$

The following discussion uses the learning of modern financial economics to analyze each of these possible benefits. It finds the first - greater fairness - the least compelling and the third efficient allocation - the most. ${ }^{69}$ The approach looks at a hypothetical issuer $X$ and a hypothetical piece of information that is relevant to predicting the future cash flows produced by $X$ 's shares. It is information that the public does not know and that management either does know or could more easily ascertain than could outsiders. The question is how, if at all, public disclosure of the information can improve anyone's position.

\section{Fairness}

A securities market is fair if the "actual value"70 of the shares that investors buy is on average at least as great as the price they

68. An auxiliary rationale would be to assist a ban on insider trading. When more is disclosed, there is less material nonpublic information on which insiders can trade. I have argued elsewhere that the reach of insider trading regulation should also be based on issuer nationality. See Merritt B. Fox, Insider Trading in a Globalizing Market: Who Should Regulate What?, LAW \& Contemp. ProBs., Autumn 1992, at 263.

69. The efficiency-enhancing features of mandatory securities disclosure have been emphasized elsewhere. See Merritt B. Fox, Shelf Registration, Integrated Disclosure, and Underwriter Due Diligence: An Economic Analysis, 70 VA. L. REv. 1005, 1015-25 (1984); Marcel Kahan, Securities Laws and the Social Costs of "Inaccurate" Stock Prices, 41 DukE L.J. 977 (1992). For other perspectives on the efficiency-enhancing features of securities disclosure, see Edmund W. Kitch, The Theory and Practice of Securities Disclosure, 61 BROOK. L. REV. 763 (1995) (arguing that while regulators chase the goal of price accuracy enhancement, the laws enacted under this banner actually work to reduce the flow of information relevant to accurate pricing of securities); Paul G. Mahoney, Mandatory Disclosure as a Solution to Agency Problems, 62 U. CHI. L. Rev. 1047 (1995) (arguing that the goal of disclosure should be focused on, and limited to, helping investors uncover breaches of contractual or fiduciary obligations); Lynn A. Stout, The Unimportance of Being Efficient: An Economic Analysis of Market Pricing and Securities Regulation, 87 MicH. L. Rev. 613 (1988) (disputing the premise that a market with accurate share prices is able to monitor or structure efficiently the allocation of scarce resources in the economy).

70. The "actual value" of a share is the future stream of income - composed of dividends and other distributions - accruing to its holders, discounted to present value. For an 
pay. More, rather than less, public knowledge about $X$ is not a necessary condition for a market to display this kind of pricing. Fairness is thus not a compelling rationale for mandatory disclosure. ${ }^{71}$

To see why this startling conclusion is correct requires a consideration of the process by which securities are priced. Securities are priced by the actions of speculators. ${ }^{72}$ Each speculator, in making her assessment of the probability distribution of future returns from holding a share of an issuer such as $X$, will include the fact that the issuer has not addressed certain matters. There is no reason to believe that the inferences that the speculator draws from the issuers' absences of comment will bias her assessments of their future returns - that is, result in her consistently over- or underestimating these returns. ${ }^{73}$ As a consequence, there is no reason to expect that

elaboration of this concept of actual value and its relationship to market price, see Fox, supra note 69 , at $1010-14$.

71. I refer here to the fairness of an issuer practice of providing less, rather than more, information. Although nothing in the law is more debated than concepts of fairness and their applicability to particular situations, the concept and application put forward here is highly defensible. It is true that any particular individual who enters into any particular transaction may end up in a worse position than if there had been greater disclosure. This would hold in the case of a purchase if (i) the price was higher than what turned out to be the shares actual's value and (ii) the price would have been lower with more disclosure. It is of course possible to argue that in this case the practice of less disclosure has led to an "unfair" result. This kind of ex post evaluation of fairness, however, seems an inappropriate way of assessing the interaction of issuers and investors in a financial market. Assume that the market displays the kind of pricing termed fair in the text. At the level of the overall economy, a practice of less disclosure will not work any overall transfer of wealth to sellers (including issuers) from buyers. At the individual level, it is true that the investor, when she decides to buy, is engaging in a larger gamble if there is less disclosure. But the odds are fair, and she knows before she acts that she is taking the gamble. The question, considered below, remains as to whether decreasing this risk by increasing disclosure is desirable, but that issue is distinct from fairness. It should also be noted that an individual purchaser is likely to engage in many different share purchases in her lifetime, and the purchases that turn out to have been overpriced are likely to be canceled out by underpriced purchases. For further elaboration of this concept of fairness, see Fox, supra note 68, at 272-74; Fox, supra note 69.

72. The term speculator is defined in Part I to mean any investor who chooses her portfolio on the basis of her beliefs concerning the future returns of available securities rather than randomly or on the basis of the security's historical Beta. These beliefs are based on the information possessed by the investor. See supra note 23 .

73. This is because the speculator makes an inference from the fact that the issuer, when not required to say something one way or the other about a certain matter, chooses not to disclose. Making an inference of this sort is the same kind of behavior that investors are assumed to exhibit in signaling theory. See, e.g., Stephen A. Ross, Disclosure Regulation in Financial Markets: Implications of Modern Finance Theory and Signaling Theory, in Issues in Financial Regulation 177 (Franklin R. Edwards ed., 1979). The claim here concerning the consequences of investors making such inferences is much more modest, however. Unlike in signaling theory, there is no suggestion here that as a result of the competitive interaction among issuers in the financial market and the motivations of management, a pattern of disclosure will develop whereby, between affirmative statements by some issuers and investor inferences from the silence of others, the exact state of affairs at each firm can be ascertained.

To see how the more modest proposition made here works, consider the following example. Suppose that country $A$ 's mandatory disclosure scheme requires an issuer to describe whether its business is distributed relatively evenly over many customers or is concentrated 
the market prices of such issuers' shares will be biased - that is, on average different from their actual values - just because the issuers are not required to address matters that a mandatory regime might require them to address. ${ }^{74}$ The finding of unbiased pricing in the

with one or a few customers. Country $B$ 's scheme does not require such disclosure. Assume that it is generally considered better in issuer $X$ 's industry to have a broad customer base. Country $A$ 's scheme does not apply to issuer $X$, and $X$ chooses not to say anything about its customer distribution. The speculator is likely to view $X$ 's future earnings less favorably than if $X$ had made an affirmative statement that it had a broad customer base. She will not, however, necessarily view $X$ 's future earnings as unfavorably as she would have if $X$ had affirmatively stated that its business was concentrated with just one or a few customers. This is because there may be a variety of reasons, besides in fact having a concentrated customer base, why $X$ might choose not to address the matter if it were not forced to, such as the usefulness of this information to competitors and customers. See infra section II.B.2. The speculator takes all the information available to her, including, if she is well informed, what she knows about the character of management in terms of volunteering bad news, the past experience with issuers generally as to what silence has turned out to mean, the existence of circumstances that would make the disclosure of good news costly for the firm, and any information available from other sources concerning $X$ 's customer base. She then makes her best guess, on the basis of all the information that is available to her, as to the probability of one state of affairs versus the other and makes her assessment of $X$ 's future earnings accordingly.

In a situation such as this example, where an issuer has not commented on a matter, the speculator on average guesses correctly. The idea behind this proposition is that each speculator's expectations concerning a share's future returns are based on the particular information within her possession. There is nothing structural in the process that determines the information received by the speculator that would lead her to underestimate or overestimate the value of a share's future returns, and so there is no reason to believe ex ante that the flow of information that goes to each speculator is going to bias that individual's expectations concerning future returns. The actual bits received may lead to an underestimate or overestimate of value in any particular assessment but, just like in sampling, the direction in which the estimate errs is purely a matter of chance. For an elaboration of this view of how investors form their subjective probability distributions concerning the future returns of securities, see Fox, supra note 25, at 76.

74. This statement relies on the premise that a lack of bias in speculators' assessments of future returns translates into a lack of bias in prices. This premise is true under a variety of theories of price formation in markets where investors have heterogeneous views concerning the probability distribution of the future value of the available securities. See, e.g., Frank H. Easterbrook \& Daniel R. Fischel, The Proper Role of a Target's Management in Responding to a Tender Offer, 94 HARv. L. REv. 1161, 1165 (1981) (theorizing that any investor possessing new information will trade to his profit on it until the price moves to the point when there are no more profits to be made because the information is fully reflected in price); Sanford Grossman, Further Results on the Informational Efficiency of Competitive Stock Markets, 18 J. ECON. THEORY 81 (1978) (theorizing that final equilibrium market prices reflect the most accurate possible prediction of future value given all information possessed by any one or more investors as a result of each investor "reading" the information possessed by the others through observation of the movement of market prices toward equilibrium); Sanford Grossman, On the Efficiency of Competitive Stock Markets Where Trades Have Diverse Information, 31 J. FIN. 573 (1976); John Lintner, The Aggregation of Investor's Diverse Judgments and Preferences in Purely Competitive Securities Markets, 4 J. Fin. \& Quantitative Analysis 347 (1969) (theorizing that prices reflect a weighted average of the views of all investors); Henry G. Manne, Mergers and the Market for Corporate Control, 73 J. PoL. Econ. 110, 112 n.10 (1965); Robert E. Verrecchia, Consensus Beliefs, Information Acquisition, and Market Information Efficiency, 70 AM. ECON. REv. 874 (1980) (theorizing that prices average the views of investors in such a way that they are more nearly accurate than the forecasts of any individual investor); Robert E. Verrecchia, On the Theory of Market Information Efficiency, $1 \mathrm{~J}$. Accr. \& Econ. 77 (1979). These theories vary in terms of the relative roles of different investors in determining price. Whatever theory one embraces, however, if the view of each 
empirical literature testing the efficient market hypothesis, ${ }^{75}$ although it concerns the ability of the market to process a different kind of information and tests immediate price reaction against longer-term prices rather than against actual value, is consistent with the proposition that the market reaction to the absences of comment by issuers that is discussed here would also be unbiased. ${ }^{76}$

individual investor is unbiased in the sense that the term is used here, then the price will be similarly unbiased.

75. See supra note 24.

76. There is a large body of financial economics literature evaluating the market reaction to the affirmative public announcement of various kinds of events affecting particular issuers. For a classic review, see KenNeth Garbade, Securities Markets 249-59 (1982). An event study involves a large number of issuers, each of which has experienced the announcement of a particular kind of event - for example, a stock split. The typical study shows that the shares of the affected firms, as a group, experience statistically significant abnormal returns at the time of the announcement and, starting almost immediately thereafter, normal returns for the duration of the study, which is sometimes as long as several years. Thus, while some issuers' share prices go up in the periods following the announcement - compared to the market as a whole - and others go down, the average change is near zero. Assuming that longer-term prices are themselves an unbiased measure of actual value, the results of the studies are thus consistent with the concept that the market's evaluation of the significance of the event for the actual value of each issuer's shares, while sometimes too high and sometimes too low, was unbiased.

Some financial economists, known as noise theorists, have attacked the EMH. They suggest that naïve speculative traders, activated by fads, fashions, or irrational psychological predispositions toward things like chasing trends, add cumulative noise to share prices so that for significant periods of time share prices end up deviating from their fundamental value the efficient market price that would prevail if the market consisted entirely of rational investors who possessed all available information. See, e.g., Fischer Black, Noise, 41 J. Fin. 529 (1986). This can happen, in their view, even if there are also smart speculators who trade with knowledge of a stock's fundamental value. The smart speculators are limited in their ability to arbitrage away the difference. Unless they have an infinite time horizon, the uncertainty created by the possibility of continued noise trading makes taking such a position inherently risky, even if they knew for certain a stock's actual value. They know at the time they are contemplating a purchase, for example, that because of noise, price may still deviate from actual value at the time they plan to sell. See J. Bradford De Long et al., Noise Trader Risk in Financial Markets, 98 J. PoL. Econ. 703 (1990). Furthermore, smart speculators in fact do not know a stock's actual value with certainty; they only have a more accurate guess, and this adds to the risk of arbitrage. See Fox, supra note 25, at 36-43, 55-59; Andrei Shleifer \& Lawrence H. Summers, The Noise Trader Approach to Finance, J. Econ. Persp., Spring 1990, at 19. An excellent survey in the legal literature of the work of the noise theorists, together with an analysis of its legal implications, is found in Donald C. Langevoort, Theories, Assumptions, and Securities Regulation: Market Efficiency Revisited, 140 U. PA. L. REV. 851 (1992).

There is considerable empirical work supporting the noise theorists' position. Robert Schiller, in a pioneering study, looked at stock prices and dividends over the last 100 years and found that stock price volatility "appear[s] to be far too high ... to be attributed to new information about future real dividends if uncertainty about future dividends is measured by the sample standard deviations of real dividends around their long-run exponential growth path." Robert J. Shiller, Do Stock Prices Move Too Much to Be Justified by Subsequent Changes in Dividends?, 71 AM. Econ. Rev. 421, 433-34 (1981). Consistent with the idea that the market overreacts to news, a number of studies suggest that share prices tend to revert toward the mean - i.e., price upswings tend to be followed by downswings and vice versa. See, e.g., Werner F.M. De Bondt \& Richard H. Thaler, Anomalies: A Mean-Reverting Walk Down Wall Street, J. Econ. PERSP., Winter 1989, at 189; James M. Poterba \& Lawrence H. Summers, Mean Reversion in Stock Prices: Evidence and Implications, 22 J. FIN. ECON. 27, 53 (1988). 
Empirical work showing that purchasers of new issues occurring after imposition of mandatory disclosure requirements under the Securities Act of 1933 did no better in their investments than purchasers of new issues in the time before mandatory disclosure is also consistent with the proposition that less information does not bias prices against the interests of purchasers. ${ }^{77}$ Other empirical

Noise theory is controversial within the financial economics community. See, e.g., Eugene F. Fama, Efficient Capital Markets: II, 46 J. FIN. 1575 (1991); Terry A. Marsh \& Robert C. Merton, Dividend Variability and Variance Bounds Tests for the Rationality of Stock Market Prices, 76 Am. Econ. REv. 483 (1986) (critiquing Shiller's dividend study). Even if noise theory were to become fully accepted, however, it does not undermine the argument in the text that prices in the market will be fair - i.e., the actual values of the shares that investors buy are on average at least as great as the price they pay - whether there is much disclosure or only a little. The fads, fashions, and irrational psychological tendencies that drive the naive speculators are as likely to be negative as positive. Uninformed investors who choose a diversified portfolio on a random basis - the practice that EMH theorists recommend to them - thus will gain as often as they lose as a result of the deviations from fundamental value, which in turn is distributed randomly around actual value.

Noise theory does predict a worse outcome than does the EMH for uninformed or irrational investors who choose to speculate - the naîve speculators. They will have a tendency to buy when prices are too high and sell when prices are too low, in the process providing profits for the smart speculators. It is highly questionable whether the concept of fairness should be expanded to condemn this wealth transfer, however, given the availability to uninformed investors of a strategy - a randomly chosen diversified portfolio - that permits participation in the benefits of equity investing without risking such losses. It would seem inconsistent for society to permit people to bet at horse races and in state-run lotteries, despite the fact that the odds are against them, but to condemn as unfair the result of uninformed or irrational speculation in the equity markets. See Shleifer \& Summers, supra, at 3031.

Even if we were to expand the concept of fairness to condemn the wealth transfer from naïve speculators to smart ones, however, it is difficult to predict whether, in a noise-theory world, more disclosure would decrease or increase the size of the transfer. On the one hand, by reducing the uncertainty associated with the smart speculators' assessments of actual value, more disclosure reduces the risk of engaging in the arbitrage activity that moves money from naive speculators to smart ones. On the other hand, the higher level of such activity will narrow the spread between price and actual value and hence the amount of damage that a naive speculator suffers each time he buys when the price is too high or sells when it is too low. Thus, even if we wished to reduce the size of the transfer, it is unclear whether more disclosure would mitigate or exacerbate the problem. Public education against engaging in naïve speculation might, for example, be more effective, as might stricter rules regulating the advice given by brokers.

77. Stigler, taking two groups of new share issues, one from the period 1923-28 (prior to the passage of the Securities Act of 1933) and the other from the period 1949-55 (after the Act's passage), compared their respective five-year post-issue growth in prices as a ratio of the growth in prices in the market as a whole. The post-Act group did not do better than the pre-Act group, see George J. Stigler, Public Regulation of the Securities Markets, 37 J. Bus. 117, 122-24 (1964) [hereinafter Stigler, Public Regulation], suggesting that mandatory disclosure did not eliminate any unfairness that was present in the initial selling price of pre-Act new issues.

Stigler's study has been criticized for computational errors that understate the performance of the post-Act group. See Irwin Friend \& Edward S. Herman, The S.E.C. Through $a$ Glass Darkly, 37 J. Bus. 382 (1964). After recalculating, however, Stigler still found that the after-issue price growth for a majority of the five years - including, most importantly, the fifth year - was still either not as good as the pre-Act group or not sufficiently better than the pre-Act group to be considered statistically significant. See George J. Stigler, Comment, 37 J. Bus. 414, 418-19 (1964) [hereinafter Stigler, Comment]. 


\section{work concerning the pricing of new issues is also consistent with the proposition. ${ }^{78}$}

Stigler's study also has been criticized on methodological grounds because of a failure to account for dividends and for differences among stocks in systematic risk, but research reveals no adequately conducted study that does take account of such factors and comes up with a different result from Stigler's, at least with respect to seasoned issuers. Jarrell conducted a study making the same comparison as Stigler but without Stigler's methodological shortcomings and came to the same conclusion as Stigler. See Gregg A. Jarrell, The Economic Effects of Federal Regulation of the Market for New Security Issues, 24 J.L. \& EcoN. 613 (1981). Jarrell's study, however, has itself been criticized. See Joel Seligman, The Historical Need for a Mandatory Corporate Disclosure System, 9 J. CoRP. L. 1, 11 n.37 (1983); Rodney T. Smith, Comments on Jarrell, 24 J.L. \& ECON. 677 (1981). Simon, in another study using the techniques of modern financial economics to consider the Stigler comparison, also agrees with Stigler's conclusions with respect to seasoned issuers and initial public issues of shares to be traded on the New York Stock Exchange, but finds that the pre-Act issues of shares to be traded on regional exchanges were significantly overpriced and the post-1933 issues were not, suggesting a category of issues in which the mandated information did eliminate a price bias that had been leading to unfairness. See Carol J. Simon, The Effect of the 1933 Securities Act on Investor Information and the Performance of New Issues, 79 Ам. ECON. REV. 295, 304-08, 313 (1989).

78. There is a prominent related literature that also concerns the performance of new share issues. This literature investigates whether the shares in these offerings are inefficiently priced at one point or another during the first several years after the initial offering. This literature does not include consideration of the effects of the level of mandated disclosure, and thus does not have clear, direct implications for the proposition in the text that fairness is unrelated to the amount of disclosure. It touches on issues sufficiently close to this question, however, to deserve comment.

A large number of studies show that initial public offerings (IPOs) are offered at a "discount" in the sense that there is, on average, a significant jump from the offering price to the price at which they trade in the initial days or weeks after the offering. See James R. Booth \& Lena Chua, Ownership Dispersion, Costly Information, and IPO Underpricing, $41 \mathrm{~J}$. FIN. ECON. 291, 306-08 (1996) (surveying empirical studies establishing the discount and testing possible explanations); Roger G. Ibbotson \& Jay R. Ritter, Initial Public Offerings, in North-Holland Handbooks of Operations Research and Management Science: FINANCE (R.A. Jarrow, V. Maksimovic \& W.T. Ziemba eds., 1992) (showing underpricing in other countries); Roger G. Ibbotson et al., Initial Public Offerings, 1 J. ApPLIED CoRP. FIN. 37 (1988) (surveying empirical studies establishing the discount and testing possible explanations). A number of explanations have been put forward, but the most recognition has been given to ones involving information asymmetry. See Janet Cooper Alexander, The Lawsuit Avoidance Theory of Why Initial Public Offerings Are Underpriced, 41 UCLA L. REV. 17, 6672 (1993); Booth \& Chua, supra, at 292-93; Ibbotson et al., supra, at 42-43. Particular attention has been paid in the literature to a model developed by Kevin Rock in which there are three kinds of actors - issuers (and their underwriters), uninformed investors, and informed investors - with the informed investors better able to determine the actual value of newly offered shares than the other two. New shares are allocated in a process in which orders are placed by investors for a given number of shares at the offering price. If the offering is oversubscribed, each investor gets a pro rata portion of the offering based on the size of his order. The uninformed investors suffer from adverse selection because they cannot separate the good deals from the bad ones and thus order equal amounts of each. They get a larger portion of the offerings for the bad deals because the informed investors do not place orders for them. In order to attract capital from the uninformed investors, IPOs need to be underpriced so that despite the adverse selection, these investors will earn a market rate of return on average. See Kevin Rock, Why New Issues Are Underpriced, 15 J. Fin. Econ. 187 (1986). This model, and variants of it working on similar themes, have received considerable empirical support. See Booth \& Chua, supra, at 306-07; Jay R. Ritter, The "Hot Issue" Market of 1980, 57 J. Bus. 215 (1984).

There is one study, by Tinic, that compares the size of the offering-price discount relative to initial trading prices for a sample of IPOs in the period 1923-30, prior to the passage of the Securities Act of 1933 and its new issue disclosure provisions, with a sample of IPOs in the 
period 1966-71, after the Act's passage. See Seha M. Tinic, Anatomy of Initial Public Offerings of Common Stock, 43 J. Fin. 789 (1988). Contrary to what would have been predicted by the information asymmetry theory, Tinic found that the discount was larger with the 1966-71 sample than the 1923-30 sample. See id. at 804-05 \& tbl.3. His explanation is that the Act created the potential for the issuer and the investment banker to incur considerable litigation costs and that the larger discount reduces both the probability of litigation and, if it occurs, its cost. The discount therefore constitutes a form of litigation insurance. See id. at 797-803. According to this explanation, the additional disclosure required by the Act either does not have the effect predicted by the information asymmetry theory or its effect is swamped by the litigation insurance factor. There are obviously severe problems in attributing the increase in the discount to this one change between the two sample periods when so many other factors have changed as well. Most of the other tests that Tinic runs concerning the size of the discount produce results that are consistent with both his theory and the information asymmetry theory. There are also errors in Tinic's description of the potential litigation costs created by the Act that diminish the force of this as an explanation of the discount. See Alexander, supra, at 26 n.28.

The fact that, on average, IPO offering prices are discounted relative to the prices at which the shares initially trade does not necessarily mean that they are discounted relative to their actual value. The studies are more mixed on this latter question. Ibbotson, in perhaps the most frequently cited study establishing the existence of the discount relative to the initial trading price, looked as well at trading prices thereafter for various periods up to five years and found returns on a risk-adjusted basis were normal, thereby suggesting that the initial trading price was efficient and that the offering price was discounted relative to actual value. See Roger G. Ibbotson, Price Performance of Common Stock New Issues, 2 J. Fin. Econ. 235, at 250-58, 265; see also Tinic, supra, at 815 . Loughran and Ritter recently came to a different conclusion. In a study that matched a large number of firms doing IPOs with comparable firms that were already publicly traded and had made no offering in several years, they found that it would, on average, require approximately a $44 \%$ larger investment in the IPO at its initial trading price to end up with the same wealth five years later as with an investment in the nonoffering matching firm. See Tim Loughran \& Jay R. Ritter, The New Issues Puzzle, 50 J. FIN. 23, 32 (1995). This inferior return swamped the initial discount of the offering price relative to the initial trading price, so that one would still have to make a $30 \%$ larger investment in the IPO at the offering price to end up with as much wealth in five years. See id. at 32 n.7. The Loughran and Ritter study thus suggests that relative to actual value, IPOs are not offered at a discount but at a large premium. See also Stigler, Comment, supra note 77, at 421 tbl.A1 (comparing, for new issues offered in the periods 1923-1927, before the Securities Act, and 1949-1955, after the Act, the average ratio of the price of the new issue shares five years after offering to market prices generally, finding the ratio for the second period is not better than the first on a statistically significant basis - which result he uses to argue that the Act led to no improvements - but also finding, without comment or a test for statistical significance, that in both periods the new issues, five years out, had underperformed the market as a whole); Hans R. Stoll \& Anthony J. Curley, Small Business and the New Issues Market for Equities, 5 J. Fin. \& Quantitative ANalysis 309 (1970) (studying issuers registering very small offerings under the SEC's Regulation A - at the time $\$ 300,000$ or less and finding that the offering prices are on average discounted relative to initial trading prices but that over the longer run investments in these shares at the offering price underperform, even without risk adjustment, a portfolio of larger stocks). Loughran and Ritter also find that SEOs - new equity offerings of "seasoned" issuers where the issuer already has publicly traded shares outstanding at the time of the offering - are similarly bad buys compared to IPOs purchased at initial trading prices. See Loughran \& Ritter, supra, at 32.

The fact that, on average, IPO offering prices are discounted relative to the prices at which they initially trade is no cause to worry on fairness grounds about the level of disclosure required for new offerings because that fact, without more, suggests that the initial purchasers are getting an unusually good deal. The empirical work supporting the information asymmetry explanation of the discount shows that issuers about which more is known can offer their shares at a lower discount. See, e.g., Ritter, supra, at 215-16, 237. This would suggest, as discussed in Part III, that, cost aside at least, issuers have an interest in being under a regime that assures a high level of disclosure. But that is an entirely different basis for concern about the level of disclosure than investor faimess. 


\section{Risk}

Just because the amount of information available in the public domain about $X$ is unrelated to the fairness of its share price does not mean that it is unrelated to the accuracy of its share price. A share price can be unbiased - no more likely to be above than below the share's actual value - but still have a low expected accuracy in the sense that there is a significant likelihood that it will deviate a substantial amount one way or the other from actual value. ${ }^{79}$

Less information about $X$ will lead to greater uncertainty among speculators about $X$ 's future. As a consequence, $X$ 's shares will have lower expected price accuracy. ${ }^{80}$ Put another way, $X$ 's shares

The possibility, raised by the Loughran and Ritter study, that both IPOs and SEOs are offered at prices in excess of actual value does raise fairness concerns, because it suggests the existence of a market inefficiency that is systematically working to the advantage of issuers and to the disadvantage of investors. Without a better understanding of why such an inefficiency has arisen, if in fact it has, and why the market has not realized it and corrected for it, we cannot decide whether the level of disclosure affects the extent of the problem and, if so, in which direction. Interestingly, Shayne and Soderquist, who recently wrote an article motivated by the Loughran and Ritter study, do not list increased disclosure among their variety of securities law reforms to counteract the reported overpricing. See Jonathan A. Shayne \& Larry D. Soderquist, Inefficiency in the Market for Initial Public Offerings, 48 VAND. L. REV. 965 , 977-86 (1995). It must also be kept in mind that these are the findings of a lone study. Even if replicated by others, they may represent the pricing of an as-yet-unidentified risk factor that is less for firms offering new issues than for comparable ones that do not, rather than an unfairness-creating market inefficiency. In addition, for the last three years of the study (1988-90), the wealth shortfall from investing in new issues disappears. This could be consistent with the market having caught onto and corrected for the inefficiency. However, the authors feel that given the particular features of these three years, this period is too short to make this conclusion. See Loughran \& Ritter, supra, at 49.

79. To put this concept of expected accuracy in statistical terms, consider price to be a random variable generated by a distribution function with a mean equal to actual value, reflecting the fact that the price is unbiased. A good measure of the price's expected accuracy would then be the variance of the distribution - the expected value of the square of the deviation from actual value. The greater the variance, the lower the price's expected accuracy.

80. The relationship between information and price accuracy is well captured by Stigler in his often-cited statement that "[p]rice dispersion is a manifestation - and, indeed, it is the measure - of ignorance in the market." George J. Stigler, The Economics of Information, 69 J. Pol. ECON. 213, 214 (1961).

Results of empirical work, also by Stigler, lend support to the proposition that disclosure of the particular kinds of information mandated by the U.S. regime for primary offerings does in fact increase price accuracy. These results come from the same study, discussed supra in note 77, comparing the post issue growth of prices (relative to the market as a whole) for two groups of new share issues, one from the period 1923-28 (prior to the passage of the Securities Act of 1933) and the other from the period 1949-55 (after the Act's passage). The variance of post issue growth of prices was lower for the second group than the first. See Stigler, Public Regulation, supra note 77, at 122, 123 tbl.3. Simon comes to the same conclusion using the methods of modern finance. She compares various post-Act periods with Stigler's pre-Act period and finds that the post-1933 groups had consistently lower variances. See Simon, supra note 77 , at 305-06 \& tbl.4. This rules out the "bull market" explanation of Stigler's results - i.e., that the greater variance in the pre-Act period was due to the fact that 
will have greater risk associated with them ${ }^{81}$ because there is a greater likelihood that what an investor receives from holding such a share - distributions and price at resale (both discounted to present value) - will deviate substantially from what she pays for it. This increased risk means that any investor holding shares of $X$, unless she is fully diversified by also holding shares of a substantial number of other issuers, will have a more risky portfolio than would have been the case if more information had been available about

it was a boom period whereas the post-1933 period he used was not. See Simon supra note 77 , at $308-13$.

The best explanation of the post-1933 group's lower variance is that additional information provided to the market from mandated disclosure caused the initial selling prices for the new issues to be closer to actual value; less correction was necessary as the future unfolded. See Friend \& Herman, supra note 77, at 390-91; Simon, supra note 77, at 311-13. The second group's lower variance can alternatively be explained as evidence that after passage of the Act more risky companies were kept out of the market by SEC regulation, see Stigler, Public Regulation, supra note 77 , at 122 , but this explanation is less persuasive. It is not clear why Stigler chose this alternative explanation other than the fact that he is suspicious of regulation of all sorts. See George Stigler, The Theory of Economic Regulation, 2 Bell J. ECON. \& Mgmt. ScI. 3 (1971). He clearly accepts the theoretical proposition that any information that is of value to investors for predicting the future with greater accuracy will lead to less share price dispersion. See supra note 80 . The results showing that the second group in fact had less dispersion logically should have led him to the conclusion that the information that the 1933 Act prompted to be disclosed was in fact of such value, unless he had affirmative evidence that led him to believe that some other factor was responsible. But in providing his alternative explanation, Stigler offers no such affirmative evidence. See Stigler, Public Regulation, supra note 77 , at 122 .

The proposition that disclosure of the information mandated by the U.S. regime for periodic disclosure - as opposed to the regime for primary offerings - increases price accuracy is harder to test. When we are forced to look at the market as a whole, it is more difficult to separate out changes in other factors affecting the market between the period before and the period after imposition of the regime. Subject to this caveat, however, there is empirical evidence that imposition of periodic disclosure requirements under the Securities Exchange Act of 1934 reduced price dispersion. Benston looked at 483 New York Stock Exchange firms for a period starting prior to the imposition of the 1934 Act regime and running to a point 90 months after imposition, using the market model to determine the absolute size of their month-to-month residuals, a measure of price dispersion. See George J. Benston, Required Disclosure and the Stock Market: An Evaluation of the Securities Exchange Act of 1934, 63 Am. Econ. Rev. 132 (1973). Of these firms, 290 disclosed sales data before imposition of the 1934 Act regime and 193 did not. After imposition, all disclosed sales data. Benston focused on whether the riskiness of the 193 nondisclosing firms declined compared to that of the disclosing firms and found no statistically significant evidence that it did. This, of course, does not prove that it did not: the effect may have simply not have been large enough to show up as statistically significant given the statistical powers of the test. Cf. Fox, supra note 24, at 1035-38 (discussing limitations of statistical analysis of another set of findings). Interestingly, Benston's results are also relevant as to the value of the total package of information required to be disclosed under the 1934 Act regime: they show that the riskiness of all 483 firms, as measured by the size of their residuals, was significantly less after imposition than before. See Irwin Friend \& Randolph Westerfield, Required Disclosure and the Stock Market: Comment, 65 AM. ECON. REv. 467 (1975). Other factors being equal, this would indicate that the total mandated package did increase price accuracy.

81. In statistical terms, the probability distribution generating the difference between the price of $X$ and its actual value, while still having a zero mean - reflecting a lack of bias will have a larger variance. 
$X .^{82}$ A significant portion of all buyers of $X$ 's shares will consequently suffer lower expected utility ${ }^{83}$ - assuming, as the capital asset-pricing model suggests, that $X$ 's shares will be priced in such a fashion that their expected return is unaffected by the greater risk resulting from lack of company-specific information. ${ }^{84}$

Two points need to be noted concerning this risk reduction benefit from greater disclosure. Each will take on particular importance when we consider a world with multiple jurisdictions and multiple open economies. First, there exists an alternative policy encouraging investors to diversify - that might be at least as effective at increasing investor expected utility. Second, even assuming no greater diversification, the nature of the lower expected utility resulting from less information needs to be carefully defined. It is not correct that $X$ 's issuance of the securities without disclosure results in lower expected utility than if $X$ had not issued its securities at all. Whatever the level of disclosure, each additional investment opportunity available to investors that a share value maximizing firm finds worth selling into a market that has unbiased pricing represents an increase in the demand for savings. The issuance therefore marginally raises the overall market expected rate of return available to investors. ${ }^{85}$ Each additional investment opportunity

82. The lack of information increases the likelihood that the actual value of an individual share of $X$ will substantially differ from price - i.e., increases its riskiness. If an investor's portfolio of high-risk assets consists entirely of shares of $X$, such an increase in the risk associated with $X$ obviously commensurately increases the riskiness of the investor's portfolio as a whole. However, the impact of such an increase in the riskiness of $X$ on the riskiness of the investor's portfolio as a whole diminishes and ultimately effectively disappears as the investor holds a larger and larger number of securities different from shares of $X$. This is because the kind of information that would be increased by $X$ disclosing more is specific to $X$. Risk due to lack of company-specific information is unsystematic and can be diversified away. See supra notes $17-18$ and accompanying text.

83. See supra note 17.

84. See supra note 37.

85. This can be seen through an example. Consider a simple world in which all proceeds from the issuance of securities go for new real investment projects, there is a fixed supply of savings, and all projects have the same amount of systematic risk, so that project risk is not a factor in the pricing of securities whose returns are related to the projects. Assume also that each firm issues a new security only when the security can be sold for more than the cost to it of funding a real investment opportunity that will provide an expected cash flow equal to the expected distributions to security holders given the terms of the security. The expected return on the project is determined by the cost of the project and its expected cash flow. The expected return on the security is determined by its price and the expected distributions to its holder.

Issuance of a security is essentially a purchase of an investor's savings. A firm pays for these savings by providing terms that result in the security having some given expected rate of return. It is advantageous to make such a purchase of savings if the rate of return on the project funded with the savings is greater than the rate of return on the securities. The demand curve for savings, $D D$ in Figure 1, thus will be identical to a curve that takes all projects being considered by all firms in rank order of their expected rates of return and depicts on the vertical axis the project's expected rate of return and on the horizontal axis the aggregate 


\section{also has a future return generated by a probability distribution with presumably at least slightly different variance-covariance character-}

amount of savings needed to fund both that project and all projects superior to it in expected rate of return. As can be seen in Figure 1, if the supply of savings is $S^{*}$, the market clearing rate of return will be $r^{*}$. If securities are sold into a market with unbiased pricing, projects on average will be funded in rank order of their expected returns down the list, up to and including the project that just exhausts the fixed supply of savings. The rate of return on this marginal project will be designated $\mathrm{r}^{*}$.

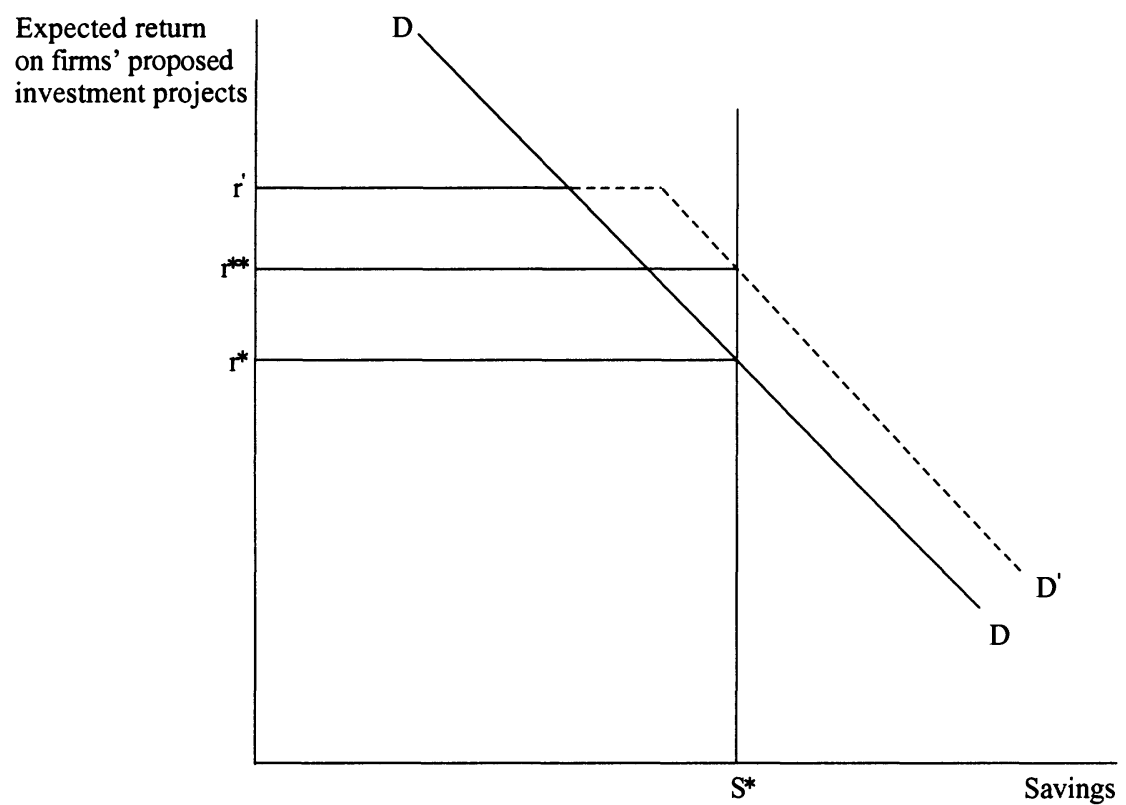

Consider what adding firm $X$ and its proposed investment project, with an expected return of $r^{l}$, does to the situation. Unless $r^{\prime}>r^{*}, X$ will not find it advantageous to issue the security at all. If $r^{l}>r^{*}$, the introduction of $X$ to the market will push the demand curve to the left for all points at or below $r^{l}$ by an amount equal to what is necessary to fund $X$ 's project. This will result in an increase in the market-clearing rate of return on securities. The intersection of supply and demand will now be at a point above $r^{*}$. X's project has "crowded out" what would have been the marginal project, the one with a return of $r^{*}$, resulting in a new marginal project with a somewhat higher rate of return, $r^{* *}$. Of course, notwithstanding the exaggerated manner in which it is presented here for purposes of illustration, in a large economy the introduction of a single additional issue with the project would have a de minimis effect. This is why the $D D$ is drawn as a smooth curve rather than stepped. But the exaggeration shows how the rate of return on securities is affected by the inclusion or exclusion of a whole class of securities - for example, securities of issuers of country $B$.

Relaxation of the assumption that savings are in fixed supply will not change the result: a higher market rate of expected return will still be needed. To the extent that a higher market rate is not needed to permit the crowding out of the marginal investment project, it is needed to coax out additional savings. Similarly, differences in systematic risk among projects require compensating adjustments in their expected returns prior to the construction of the demand curve for savings. The existence of security issues for purposes other than new real investment is more complex. In general, however, anything that is not used for new real investment is a refinancing, and the proceeds of such refinancing are returned to the market so that the supply of savings is not diminished and the marginal real investment project still determines the market rate of retum. 
istics than any existing opportunity. Each additional opportunity therefore permits investors to compose portfolios with more favorable trade-offs between risk and return than otherwise would have been available. ${ }^{86}$ Any attempt to increase investor expected utility through risk reduction thus will be counterproductive if requiring $X$ to disclose more deters it from offering its shares in the first place.

\section{Efficient Allocation of Resources ${ }^{87}$}

The amount of information available about $X$ - and hence its share price accuracy - has a second kind of effect on the economy: allocative efficiency. The securities market monitors and structures the allocation of scarce resources in the economy. It influences in important ways which proposed investment projects are implemented and how the economy's existing productive capacity is used. Most of these choices are made, at least in the first instance, by entrepreneurs setting up new corporations and by the managements of existing corporations. Security prices and the information used to establish them are central to the mechanisms that limit the discretion of the entrepreneurs and managers who make these choices. The three key mechanisms are: the cost of capital to individual corporations, the market for corporate control, and share-price-based management compensation.

a. The Cost of Capital and Project Choice: The Role of Disclosure at Time of a New Share Offering. To understand how lack of information and resulting share price inaccuracy can affect which proposed investment projects are implemented, consider the following stylized facts. Suppose that $X$ and $Y$ are new firms, yet to be capitalized. In each case, the firm is incorporated by proponents of a proposed new investment project who hope to attract funds to implement it. Each firm is considering a new investment project of equal cost and equal risk. Anyone who knew what the respective firm proponents know about the details of the projects would conclude that $Y$ 's project has a higher expected cash return than $X$ 's. The proponents of each project investigate the market to determine the amount they would receive for their equity. Suppose that $X$ 's shares will be overpriced. Proponents of $X$ might find that they can raise sufficient funds to cover the cost of implementing the project

86. See supra section I.A.2.

87. This discussion is substantially based on a more developed discussion concerning these same issues in a purely domestic context appearing in Fox, supra note 69, at 1018-22. 
without having to offer the public all of $X$ 's equity. The rest of the equity, which will cost the proponents very little, will be retained by them. The proponents therefore will be able to enjoy an "entrepreneurial surplus" - value added to these retained shares because of their pro rata claim on expected positive cash flow generated by the project.

Suppose, on the other hand, that $Y$ 's shares will be underpriced. Proponents of $Y$ might find that they cannot raise sufficient funds to cover the cost of implementing the project even by offering to the public all of $Y$ 's equity. Under these circumstances, the $X$ proponents, attracted by the entrepreneurial surplus, will decide to go ahead, while the $Y$ proponents will decide not to go ahead. Because of inaccurate security prices, scarce resources will be used to implement $X$ 's project, even though $Y$ 's project is superior.

If $X$ and $Y$ are instead ongoing corporations, each considering its project as an additional investment, a similar though more complicated story can be told about the results of inaccurate share prices. Share price is likely to be inversely related to management's perception of its "cost of capital," the figure that management weighs against a given investment project's expected benefits when deciding whether to undertake a given investment project. An inaccurately high $X$ share price and an inaccurately low $Y$ share price can therefore lead to implementation of $X$ 's project and not $Y$ 's project. ${ }^{88}$

b. The Market for Corporate Control and Stock Price-based Incentives: The Role of Ongoing Disclosure After Shares have been Publicly Sold. When the choices made by the managers of existing corporations concerning which new projects to implement and how to use existing capacity maximize shareholder wealth, they are generally presumed also to constitute the most efficient allocation of resources. ${ }^{89}$ There is no assurance, however, that the managers of corporations will make the choices that maximize shareholder wealth. Management may not be competent, and even if it is, its best interests sometimes differ from those of the shareholders. A

88. The relationship between share price accuracy and project choice by ongoing corporations is explored in more detail in id. at 1016-18.

89. Conventional economic theory holds that in a competitive economy in which antisocial behavior, such as pollution, is properly regulated, management decisions that are best for existing shareholders also allocate the economy's scarce resources most efficiently. See WILliam J. Baumol, Economic Theory and Operations ANalysis 395-400 (4th ed. 1977); Milton Friedman, Capitalism and Freedom 133 (1962); Paul A. Samuelson \& WilLIAM P. NORDHAUS, ECONOMICS 678 (12th ed. 1985). 
corporate manager, like anyone, can be expected to value compensation, perquisites, respect, power, affection, a sense of rectitude, and job security. The decisions the manager makes for the firm may affect the level of all these rewards. The extent to which a manager makes decisions that are in the best interests of shareholders depends on the structure of incentives in which she operates. As developed below, the amount that is publicly known about a corporation can affect these incentives in important ways.

i. The Market for Corporate Control. One obvious way that shareholders might prevent management decisions that are not in the best interests of shareholders is for them to replace an unsatisfactory management by electing one more to their liking. But many large corporations, especially in the United States, are "management controlled." Share ownership is so dispersed that management can perpetuate itself indefinitely by controlling the firm's proxy machinery and nominating as directors its own members and persons friendly to current management. ${ }^{90}$ Concerted shareholder

90. See William L. Cary \& Melvin Aron Eisenberg, Corporations: Cases and Materials 241-44 (7th ed. 1995); Edward S. Herman, Corporate Control, CorpoRATE POWER 54 (1981). Herman estimates that 78 of the largest 100 industrial corporations and 165 of the largest 200 nonfinancial corporations are management controlled. See id. at 58-61; see also John P. Palmer, The Separation of Ownership From Control in Large US Industrial Corporations, Q. Rev. Econ. \& Bus., Autumn 1972, at 55-57 (finding that in 1965, 101 of the largest 125 firms and 176 of the largest 250 firms were management controlled, and in 1969 management controlled 99 and 171, respectively). A sense of the share of the economy's allocation decisions that are made by the managements of these management controlled firms comes from the congressional testimony of Michael Pertschuk, former Chairman of the Federal Trade Commission. He estimated that in 1977 the largest 200 manufacturing corporations held $60 \%$ of all manufacturing assets and that in 1976, 451 firms controlled $70 \%$ of all manufacturing assets. See Mergers and Industrial Concentration: Hearings Before the Subcomm. on Antitrust and Monopoly of the Senate Judiciary Comm., 95th Cong. 155 (1978) (statement of Michael Pertschuk).

Some American legal scholars have suggested that the increasing percentage of share ownership by institutional investors creates the potential for more concerted shareholder action. See, e.g., Bernard S. Black, Shareholder Passivity Reexamined, 89 MICH. L. REv. 520 (1990); John C. Coffee, Jr., Liquidity Versus Control: The Institutional Investor as Corporate Monitor, 91 Colum. L. Rev. 1277 (1991); Alfred F. Conard, Beyond Managerialism: Investor Capitalism?, 22 U. Mich. J.L. REF. 117 (1988); Ronald J. Gilson \& Reinier Kraakman, Reinventing the Outside Director: An Agenda for Institutional Investors, 43 Stan. L. Rev. 863 (1991); Mark J. Roe, A Political Theory of American Corporate Finance, 91 Colum. L. REV. 10 (1991). Reports concerning management changes at a number of the largest U.S. corporations in the last several years suggest that institutional investors are in fact beginning to play a greater role. See, e.g., Brett D. Fromson, American Express: Anatomy of a Coup, WASh. Post, Feb. 11, 1993, at A1; Doron P. Levin, Stempel Quits Job as Top G.M. Officer in Rift with Board, N.Y. TImes, Oct. 27, 1992, at A1; Steve Lohr, Big Business in Turmoil: Upheavals at I.B.M., Sears and Elsewhere Underline Fundamental Shifts in Economy, N.Y. Times, Jan. 28, 1993, at A1; Steve Lohr, I.B.M. to Replace Its Top Executive, N.Y. TimES, Jan. 27, 1993, at A1.

Even if institutional investors are playing a larger role in corporate governance, their likely impact is enhanced by greater public disclosure. Institutional investors are hampered in obtaining needed information through private contacts with corporate officials by the con- 
action to vote management of such companies out of office is difficult. On the other hand, if an existing shareholder or an outsider can purchase enough shares of the corporation to obtain a controlling interest, he can replace incumbent management on his own. ${ }^{91}$ The existence of such a market for corporate control results in takeovers that terminate incompetent or self-interested management. Equally important, the fear of a takeover will motivate incumbent management to make decisions more in accord with the best interests of shareholders than it might otherwise make.

The effectiveness of the market for corporate control in restricting management discretion depends on the accuracy of the price of a firm's shares and the quality of information available to the market concerning the firm's operations, both of which are enhanced by greater disclosure. To see the relevance of the accuracy of a firm's share price, consider the following example.

Suppose that the incumbent management of a firm (the target) is making decisions that are not in the best interests of its shareholders. An outsider is aware of this mismanagement and thinks that it could do a better job. Assume for a moment that the outsider is certain of how much the target will be worth in its hands..$^{92}$ If the target's share price accurately states the value of the firm assuming the continuation of incumbent management, the outsider will find a takeover worthwhile. The price it must pay to acquire the shares necessary to effect the takeover will be less than what the shares will be worth once it is in control. But if the price is inaccurate and the inaccuracy sufficiently overstates actual value, the takeover will not be worthwhile, notwithstanding the poor quality of incumbent management's decisions and the outsider's certainty as to the greater worth of the target in its hands. The more inaccurate share prices are generally, the more cases there will be where

cern that they will end up with material nonpublic information, the possession of which will prevent them from legally trading in the issuers' shares. Also, their willingness to incur costs to ferret out information is still limited by information's public-good nature: each institutional investor receives only a small portion of the total shareholder gain when the information obtained leads, through shareholder pressure, to better corporate decisions. See Merritt B. Fox, Required Disclosure and Corporate Governance 4-6 (May 16, 1997) (unpublished paper, presented at the Symposium on Comparative Governance, Max-Planck-Institut, Hamburg, Germany, on file with author).

91. See Henry G. Manne, Mergers and the Market for Corporate Control, 73 J. PoL. ECON. 110 (1965). A brief survey of the work in this area is found in F.M. SCHERER \& David Ross, Industrial Market Structure and Economic Performance $42-43$ (3d ed. 1990).

92. This assumption of certainty is unrealistic, and its unrealism makes the market for corporate control appear more effective on average than it really is in restricting management discretion. 
the takeover mechanism will fail because the target's share price is too high.

To see the relevance of the quality of information available to the market, consider a variation on the example above. Assume, more realistically, that the outsider's assessment of the value of the target in its hands, though unbiased, is uncertain. The outsider is not perfectly informed about the future. Thus, the outsider knows that in any particular case its assessment is equally likely to be too high or too low and is unlikely to be exactly right. In this situation, even if both the price of the shares and the assessment are correct, the outsider cannot be confident of these facts. If risk averse, the outsider may not undertake the takeover, despite the expected gain from doing so.

The outsider's fear results from the all-or-nothing aspect of a takeover. The outsider must acquire a certain number of shares or it will be unable to effect the transfer of control on which its expectation of gain is based. For a target corporation of any significance, this minimum number of shares would constitute a large investment relative to the size of the typical outsider's portfolio. Altering the portfolio to include these shares would add to its riskiness because the unsystematic component of the risk could not be fully diversified away. The outsider's expected gain from the transfer of control may not be sufficient to compensate for the added risk. When more information about a potential target is available to the market, less unsystematic risk will be involved in an outsider's assessment of what the firm would be worth in its hands, and less expected gain will be necessary to motivate the outsider to undertake the takeover.

ii. Share-Price-Based Compensation. The role of share price is not confined to the operation of the market for corporate control. A number of management compensation devices - stock options, stock appreciation rights, warrants, and employee-stock-ownership plans - depend on share price to determine the magnitude of the reward given the recipient. ${ }^{93}$

Everything else being equal, the compensation scheme that would most effectively align management interests with those of shareholders, and hence the most efficient allocation of resources, would be entirely stock price based. In recent years this point has been given increasing attention in the discussion of how to improve

93. See SCHERER \& Ross, supra note 91 , at $45-46$. 
the performance of U.S. corporations. ${ }^{94}$ It would be the most attractive package to shareholders and management alike because a portion of the gains from more efficient allocation would be available to each. At the beginning of the year, management would receive a compensation package with a higher expected yield than if the package were not stock price based, but not so much higher that shareholders would receive none of the benefits from the resulting improvement in management decisions. ${ }^{95}$

Everything is not equal, however, and the problem again is risk. Compensation based on share price might end up well above or well below what is expected. For the typical manager, job compensation is a large part of annual income, so this risk cannot be diver-

94. See, e.g., Michael C. Jensen \& Kevin J. Murphy, CEO Incentives - It's Not How Much You Pay, but How, Harv. Bus. Rev., May-June 1990, at 138. A critical review of the literature advocating greater share-price-based compensation for management can be found in Merritt B. Fox, Insider Trading Deterrence Versus Managerial Incentives: A Unified Theory of Section 16(b), 92 MicH. L. REv. 2088, 2096-106 (1994). The superiority of a stock-pricebased compensation scheme can be seen in terms of the shortcomings of its alternatives. The promise of year-end bonuses and future salary increases based on merit are devices by which top management, as a group, can reward those members who have made decisions contributing to the group's goals. Incentives awarded by a management group, however, will protect shareholders only if there is a way to align the interests of the group with those of the shareholders. A profit-sharing arrangement may work to align management and shareholder interests to some extent. A defect in those plans is that "profit" is an accounting figure that at best captures only imprecisely many of the gains and losses experienced by a firm. For example, research and development expenditures generally cannot be capitalized and must be treated as a current expense, even though they may enhance the future revenues of the firm as much as capital expenditures for bricks and mortar. See Financial Accounting StanDards Board, Statement of Financial Accounting Standards No. 2: Accounting FOR RESEARCH AND DEVELOPMENT COSTS 6 (1974). Thus, profit-sharing arrangements often create incentives to make decisions that emphasize a firm's short-run performance over its long-run performance. In contrast, when a manager, in choosing among the alternative courses of action, chooses the option that most benefits the firm, that choice will on average have the most positive immediate effect on share price, even if the benefit will not be realized until some point in the future.

There is evidence that a compensation package that emphasizes stock returns results in management decisions more in the interests of shareholders. See Robert Tempest Masson, Executive Motivations, Earnings, and Consequent Equity Performance, 79 J. PoL. EcoN. 1278, 1289 (1971) (finding that firms that tie executive compensation to stock returns perform better than those that do not); Kevin J. Murphy, Corporate Performance and Managerial Remuneration, 7 J. Accr. \& ECON. 7, 25-37 (1985) (showing a similar correlation for salary and bonus even before adding in employee stock options and stock appreciation rights). The fact that compensation is structured in a way that creates incentives for increasing shareholder wealth does not necessarily mean that it is the incentives that made the better-performing managers perform the way they did; correlation does not establish causation. It is possible that the typical manager in the study was unaffected by the incentive structure under which he worked, but that the board, which at the beginning of the manager's tenure was not sure of his abilities, observed firm performance over time and then began paying him what he was worth. For an example of this kind of "learning" theory of compensation, see Milton Harris \& Bengt Holmstrom, A Theory of Wage Dynamics, 49 REv. Econ. STud. 315 (1982).

95. The concept that it can be in the interests of both shareholders and management to develop an incentive structure that limits management discretion derives from agency theory. See Michael C. Jensen \& William H. Meckling, Theory of the Firm: Managerial Behavior, Agency Costs and Ownership Structure, 3 J. FIN. Econ. 305 (1976). 
sified away. A manager thus will want at least part of his total compensation scheme to include less risky elements, such as straight salary. The higher the expected accuracy of a firm's share price, however, the less risky stock-price-based compensation and the larger the portion of the total package he will be willing to accept in this form. ${ }^{96}$ Greater disclosure, therefore, will enhance the efficient allocation of resources in this fashion as well.

\section{B. Costs of Greater Disclosure}

Disclosure involves costs as well as benefits. The easiest way of identifying these costs is first to consider the private costs of the individual issuer in making additional disclosure, and then to consider disclosure's costs in terms of larger groups: issuers as a class and the economy at large.

\section{Private Costs of Disclosure to the Individual Issuer}

a. Operational Costs. The most obvious costs of greater disclosure to an individual issuer are the operational costs. The issuer must gather and evaluate the necessary information, and then compose and disseminate a message to the public. These operational costs inevitably involve the time of the issuer's officers and employees. They may also involve fees for lawyers, accountants and other experts, and for printing, particularly in the case of disclosure that is legally mandated and required to be in a particular form. Mandated disclosure is also likely to involve governmental "user" fees intended in some fashion to recompense the administering agency for its expenses. ${ }^{97}$

b. Interfirm Costs. Disclosure is likely to involve nonoperational costs as well, which I shall refer to as "interfirm" costs. For

96. There is empirical evidence to support the proposition that a reduction in the riskiness of an issuer's stock will increase the proportion of compensation a manager will be willing to take in stock price based form. Holderness, Kroszner, and Sheehan compare the percentage of shares owned by officers and directors in a representative sample of exchangelisted U.S. firms in 1935 and one in 1995 and finds that it increased from $13 \%$ to $22 \%$. They find that the relationship between ownership and performance is very similar in the two periods. The most promising explanation of the change is the reduction in stock price volatility between the first and second periods. See Clifford G. Holderness et al., Were the Good Old Days that Good? Evolution of Corporate Ownership and Governance since the Great Depression (Oct. 8, 1996) (unpublished paper presented at the University of Michigan Department of Economics Economic History Seminar, on file with author).

97. For example, the Securities and Exchange Commission charges initial issuers a filing fee of one-fiftieth of 1 percent $(0.02 \%)$ of the maximum offering price of the securities being sold. See Sec. Act Rule 457, 17 C.F.R. § 230.457 (1996); see also Loss \& SEligman, supra note 3 , at 339 . 
an individual firm, being forced to disclose certain information can, looked at in isolation, increase its costs or decrease its revenues because of use of the information by competitors, major suppliers, or major customers. Competitors can act in ways that reduce the issuer's rents, if they know the issuer's lines of business that are unusually profitable or the kinds of products or activities that the issuer's research suggests will be unusually profitable in the future. Suppliers and customers who deal with the issuer on a negotiated basis can strike bargains more favorable to themselves when armed with this kind of information. The information enhances suppliers' and customers' bargaining positions because it gives them a better idea of the size of the potential surplus created by their deals with the issuer.

\section{Costs of Disclosure to Issuers as a Class and to the Economy as a Whole}

It would be misleading, however, to stop the analysis at the level of the individual firm. A widespread disclosure practice, whether prompted by a mandatory regime or other pressures, involves the issuer's competitors, suppliers, and customers providing information comparable to what the issuer provides. The information provided by these other firms can be useful to the issuer. Depending on the particular issuer, these countervailing gains may equal or exceed the nonoperational, "interfirm" costs that the issuer incurs as a result of the practice. Looking at the question across the whole economy, the average issuer will gain as many advantages from knowing more about its competitors, suppliers, and customers as these firms will gain from knowing about the issuer. Thus, the private, individual firm cost of disclosure, which includes both operational costs and interfirm costs, will be greater than the social costs of that disclosure, which will approximately equal the operational costs alone. As a result, absent regulation, firms can be expected to disclose less than is socially optimal.98

We cannot, however, stop quite here. The effects of greater disclosure on the level and distribution of rents in the economy has implications for its static and dynamic efficiency in ways that go beyond the ordinary domain of financial economics and of the debate on the virtues and vices of mandatory disclosure. ${ }^{99}$ The effect

98. See sources cited infra note 143 .

99. Static efficiency refers to enhancing economic welfare through reallocation of the existing fixed supply of productive resources in a world with a given technology. Static efficiency is maximized when these resources are allocated in a Pareto-optimal fashion - that is, 
on static efficiency is positive: increased disclosure will lead to more effective competition and hence a reduction in the allocative distortions associated with monopoly rents. The effect on dynamic efficiency is negative: increased disclosure reduces the rewards for developing knowledge that identifies new markets and new products in any area unprotected by patents or copyrights. It in essence reduces the scope of what is considered proprietary information. ${ }^{100}$ Thus, a proper calculation of the welfare effects of greater disclosure must include not only balancing its benefits for the finance process against its operational costs but also considering these static and dynamic efficiency effects.

\section{The Stakes of Individual Countries in the Disclosure of Transnationally Traded Issuers}

How are the benefits and costs of increased disclosure distributed among multiple countries? In the world of the near- and medium-term future, transnational transactions will be becoming increasingly important, but most issuers will still have clear national identities and disclosure regulation will still be undertaken by national authorities. In assessing the stakes of each of the countries involved, this article confines itself to transactions in which the place of the transaction is either the issuer's country or the buyer's country of residence and, in the case of secondary transactions, in which the buyer and seller are of the same country of residence. This greatly simplifies the analysis without significantly reducing understanding. ${ }^{101}$

when no one's welfare can be further improved by a resource reallocation without some other person's welfare being diminished. Perfect competition among profit maximizing firms, when combined with the satisfaction of certain other conditions, will result in a Paretooptimal allocation of resources. See James M. Henderson \& Richard E. Quandt, Microeconomic Theory: A Mathematical Approach 255-64 (2d ed. 1971).

Dynamic efficiency refers to enhancing economic welfare through implementation of technological change that permits, from the existing fixed supply of productive resources, either a larger output of existing products or the output of new products more valued by consumers than what was produced before. The conditions, if any, under which competition promotes dynamic efficiency and the ones, if any, under which monopoly encourages it are a matter of intense debate among industrial organization economists. I have given a critical overview of this debate elsewhere. See Fox, supra note 25, at 199-202.

100. Edmund Kitch takes note of this rent-reducing feature of disclosure to argue that issuers have an interest in not complying with mandatory disclosure rules and to question the practicality of the regime. See Kitch, supra note 69 , at 846-74. The other way of looking at this, of course, is to conclude that this rent-reducing feature of disclosure is exactly why we cannot count on disclosure being provided voluntarily, even in circumstances in which its social benefits exceed its social costs. This is why we need a mandatory regime.

101. Given that three dimensions of transnational transaction nationality are being considered here, such a transaction can involve as many as three countries. Including threecountry transactions in the analysis, however, would add considerably to the complexity of 
So confined, all transnational transactions fall into one of three general categories. The first is the "standard" transaction. Here the investor buys or sells the securities involved in the securities market of his country of residence, but the issuer is of a different country. The second category is the "transplant" transaction. The investor buying or selling the security and the issuer are of the same country, but the transaction is effected in another country. The third category is the "issuer country" transaction. Like the standard transaction, the buyer is of a different country than the issuer, but, unlike the standard transaction, the transaction is effected in the issuer's country.

\section{Types of Transactions Involving Shares of $B$ Issuers}

\begin{tabular}{l|ll|l|}
\multicolumn{1}{c}{} & \multicolumn{2}{c}{ B } & \multicolumn{2}{c}{ Buyer's Residence } \\
\cline { 3 - 4 } $\begin{array}{c}\text { Place of } \\
\text { Transaction }\end{array}$ & A & Standard & Transplant \\
\cline { 2 - 3 } & B & Issuer Country & Domestic \\
\cline { 3 - 4 } & & &
\end{tabular}

The discussion below is organized around these three categories of transactions. For each category, it considers the stakes of the associated countries in the disclosure practices of the issuers of the shares involved. The focus is on two countries, $A$ and $B$. The issuers involved are "nationals" of $B$, meaning that the residences of the entrepreneurs who founded them, the issuers' principal places of business, and the largest portions of their operations are in country $B .{ }^{102}$ The discussion of each of the three categories assumes that there are no public transactions, including purely domestic ones, in the shares of the issuers involved outside of the category being considered. Despite being generally at odds with reality, this simplifying assumption is helpful because it sets up the most extreme set of facts against which to test the propositions made. As a result, by the end of the discussions of the three

the presentation without a significant gain in elucidating the underlying principles. Threecountry transactions are also probably much less common than two country ones. Where the buyer and issuer are of different nationalities, the buyer is likely to buy either in his home market, where his transactions costs are lowest, or, if the security is not available there, in the home market of the issuer, which would typically be the most developed market for the issuer's securities. Thus, typically only two countries will be involved because the place of the transaction is either the same country as the issuer or as the buyer.

102. The following discussions of the three categories are obviously equally applicable to the other possible standard, transplant and issuer country transactions involving $A$ and $B$, where the issuer is from $A$; all that is necessary is a reversal of all the country names. 
categories, a clear understanding will emerge of how, whatever the actual overall mix, the residence of the investor, the nationality of the issuer, and the place of any given transaction give rise to distinct stakes in the disclosure practices of the issuer involved.

\section{A. The Standard Transaction: Buyer From A; Transaction Occurs in A; Issuer From B \\ 1. The Stakes for Country A, the Country of the Buyer}

In the "standard" transnational transaction, the investor buys the securities involved in the securities market of his country of residence. The transaction is transnational because the issuer is of a different country. Such a transaction is "standard" because, given the investor's desire to minimize transaction costs, he would naturally choose to purchase the security in his home market if it was available there. The issuer will naturally promote such availability, if the potential volume of transactions in the investor's home country were sufficient to support a market for the security and the issuer were not deterred by securities law considerations. As a result of these factors, transnational transactions in the standard category have occasioned the most frequent legal consideration and are therefore the subject of the most developed jurisprudence.

We will use as our example standard transnational transactions in the shares of issuers $X$ and $Y$, nationals of country $B$. We will thus focus on sales in country $A$ of $X$ and $Y$ shares to residents of $A$ and trades in such shares among such residents. Remember that we assume that these transactions are not accompanied by any public sales to, or trades among, $B$ residents. In essence $X$ and $Y$ are public companies only abroad. We will explore the respective stakes of countries $A$ and $B$ in $X$ 's and $Y$ 's disclosure practices by identifying the consequences for each country if $X$ or $Y$ reveals less rather than more about itself.

a. Fairness and Risk. First, observe that country $A$ has no stake in the disclosure practices of $X$ and $Y$ based on concerns about fairness for its investors. Greater fairness is simply not a benefit generated by greater disclosure. As we saw in Part II, reducing the amount of publicly available information about issuers like $X$ and $Y$ may increase the uncertainty that the share price reflects its actual value, but it will not bias the share price. Regardless of the level of disclosure by $X$ and $Y$, investors in $A$ will not be buying the 
shares of these issuers at prices that are, on average, greater than their actual values. ${ }^{103}$

Risk, as we have seen, is a different matter. If $X$ or $Y$ discloses less about itself, its share price will be less accurate. Investors holding its shares in less than fully diversified portfolios will face increased risk and hence lower expected utility. Because all public investors in $X$ and $Y$ are residents of country $A, A$ will be the country that receives this benefit from any increased disclosure by $X$ or $Y$. As we have also seen, however, this observation is subject to two caveats. First, the same benefit may be obtainable, probably at less cost, by persuading investors in $A$ to diversify more. Second, investors in $A$ are better off having shares in $X$ and $Y$ available to them, even with minimal disclosure, than not available to them at all. Country $A$ would be hurting, not helping its investors, if a policy of extending its mandatory disclosure regime to foreign issuers

103. This statement needs some elaboration to the extent that the world more closely resembles the one described by the noise theorists than the one described the EMH theorists. See supra note 76 (discussing, in the context of a closed economy, disclosure's effect on fairness in a noise-theory world).

First, consider secondary trading. Under the assumptions of the analysis in the text, all public trading of $X$ and $Y$ shares is among investors in $A$. Whatever the level of $B$ issuer disclosure, such trading cannot effect any kind of wealth transfer between country $A$ and country $B$. For investors within $A$ buying $B$ issuer shares, price, as in the closed-economy discussion, will be fair in the sense that on average it will equal actual value. This guarantees that uninformed $A$ investors who choose a diversified portfolio of $B$ issuers' shares, on a random basis, are likely to be unaffected by the disclosure level. Noise theory predicts a wealth transfer between the other two groups in $A$ investing in $B$ issuers' shares - the smart speculators and the naïve speculators - as the former profit in their arbitrage activities at the expense of the latter. As in the closed economy discussion, expanding the concept of fairness to condemn such a transfer is highly questionable. Even if fairness were so expanded, it is unclear whether more disclosure would exacerbate or mitigate the problem.

If we relax the assumption in the text that all public secondary trading of $X$ and $Y$ shares is among investors in $A$, and if the proportion of transactions by smart $B$ speculators versus naive $B$ investors differs from the comparable proportion of $A$ investor transactions, noise theory predicts a transfer of wealth to the country with the higher proportion of smart speculator transactions. Again, however, the direction of the effect of greater disclosure on the size of this transfer is unclear.

A primary offering, with or without such a relaxation of the assumption in the text, involves at least indirect transactions between residents of $A$, as purchasers, and a resident of $B$, the issuer - usually with an investment banker acting as an intermediary. However, as discussed previously, the empirical literature comparing new issues in the United States before and after passage of the Securities Act of 1933 does not show that the resulting increase in disclosure improved the fortunes of the purchasers. See supra notes 77-78. This suggests that the level of disclosure had no effect on the faimess of initial-offering prices. So, at least as a general matter, country $A$ has no faimess stake in the disclosure level of issuers from $B$ engaging in even primary offerings of securities. The possible exception to the conclusion that disclosure has no effect on average offering price relates to initial public offerings of shares that were to be traded only on a regional stock exchange rather than on the New York Stock Exchange. Simon found that these issues were on average overpriced. See Simon, supra note 77, at 304-08. Simon's findings suggest that country $A$ might have a stake in the disclosure level of those issuers from country $B$ that engage in initial public offerings that will not then be traded on one of the world's major exchanges. 
resulted in $X$ and $Y$ shares not being available to these investors in the first place.

b. Efficient Allocation of Resources and Cost. We saw in Part II that less disclosure at the time that new shares are offered to the public leads to allocational inefficiencies because of its effect on which real investment projects are implemented. Less ongoing disclosure also lessens allocational efficiency because it reduces the effectiveness of the market for control and share-price-based compensation as devices for limiting managerial discretion. On the other hand, less disclosure of either kind also reduces costs. The question to be addressed here is the extent, if any, to which residents of $A$ experience either of these effects.

i. A Simplified World of Only Initially Capitalizing Firms. We will start with a simplified world in which all the $B$ issuers are firms seeking capital just once. Each invests in a single project. Project return is determined only by the quality of the project idea, not the quality of management. Thus the only time a firm discloses is at the time it seeks its capital. The only allocational gain from greater disclosure is improved project choice.

Assume, as in the example in Part II, that firms $X$ and $Y$ are each offering shares to fund equally expensive proposed projects. Anyone who knew what the respective firm entrepreneurs knew about the projects would conclude that $Y$ 's project has the higherexpected cash return. Remember that less accurate share prices increase the likelihood that $X$ 's project will be implemented and $Y$ 's project will not be. Less disclosure results in less accurate prices. In a market in which there are many $X$-type and $Y$-type firms, a general practice of less disclosure by such firms will thus mean a higher number of such misallocations.

Three groups share in the returns generated by the activities of these firms: the suppliers of the entrepreneurial talent, the public suppliers of capital, and the suppliers of the other factors of production. The first and third groups consist entirely of $B$ residents, the second entirely of $A$ residents. The losses from misallocation can only come from one or more of these three groups. As shown below, because of capital's mobility the suppliers of capital will not be hurt. Nor will suppliers of capital bear any of the costs of whatever level of disclosure is provided. Thus country $A$ has no stake, based on resource allocation or cost concerns, in the disclosure practices 
of country $B$ issuers, even those that raise their public capital exclusively through stock sales to $A$ residents.

This conclusion is derived as follows. The greater the ignorance in the market and, hence, share price inaccuracy, the greater the misallocation of capital. For any given amount of capital flowing from $A$ to $B,{ }^{104}$ there will be more instances of inferior projects being implemented and superior ones not. This will reduce the implemented projects' average cash return. Since country $A$ 's investors can make unbiased, though not fully accurate, evaluations of what each project's cash return will be, their awareness of the market's greater ignorance will lead them to discount their expectations concerning the project cash returns of all $B$ issuers. They know that greater ignorance will lead to more misallocations, but they do not know which issuers' projects are inferior.

Cash return on a firm's initial project is the ultimate source of all cash distributions to shareholders. ${ }^{105}$ Lower project cash return will mean lower cash distributions to shareholders. These cash distributions are divided between two groups of shareholders: the public shareholders in $A$, who exchange the capital necessary for the project for shares representing whatever percentage of the issuer's total equity they demand to provide that amount of funds, and the entrepreneurs, who receive whatever equity remains. $\mathrm{Re}-$ gardless of whether the levels of expected cash returns on the projects of country $B$ issuers and their consequent expected total cash distributions to these two groups of shareholders are high or low, investors in country $A$ will demand the same level of expected cash distributions. Investors in $A$ have a large supply of alternative investment opportunities. ${ }^{106}$ Lower total expected shareholder

104. The analysis that follows shows that, everything being equal - including the amount of funds flowing out of $A$ to purchase shares of $B$ issuers such as $X$ and $Y-$ the misallocations from lower disclosure will reduce returns to entrepreneurs in $B$ and leave investors in $A$ unaffected. The actual amount of capital flowing from $A$ to $B$ in fact will be lower because the reduction in entrepreneurial surplus will reduce the number of investment opportunities from $B$ supplied to the market.

105. This is true on a discounted basis whether the project cash return is paid out at the time received or is retained and reinvested with the distributions to shareholders coming instead from the cash return on the reinvestment.

106. The proposition in the text treats country $B$ as a producer of investment opportunities - rights to receive a return at a given point in the future with given risk characteristics and an expected value at the time of payout of one dollar. It assumes that investors in $A$ face a market in which each such opportunity, whether from $B$ or elsewhere, will be priced the same and that the price will not change materially depending on whether $B$ offers fewer such opportunities - that is, $B$ issuers have low expected total cash distributions to shareholders - or more - that is, $B$ issuers have higher expected distributions. The proposition thus analogizes $B$ to a firm selling a product in a perfectly competitive market in which, according to standard microeconomic theory, its level of production will have no material effect on price. 
cash distributions of $B$ issuers will simply result in investors in $A$ demanding a right to receive a commensurately larger proportion of distributions before they provide the capital necessary to implement $B$ issuer projects. In other words, investors in $A$ will receive a larger proportion of total equity, and the entrepreneurs in $B$ will get a smaller proportion. Between the two groups of shareholders, the harm to project choice from lower disclosure thus will fall entirely upon entrepreneurs in $B$. For the same reasons, these entrepreneurs will also bear the costs involved in whatever disclosure is provided.

\section{ii. A World With Ongoing Issuers and Ongoing Disclosure.} Now enlarge the world to include issuers that have an ongoing existence. The managers of these issuers from time to time decide to implement new projects. Once a project is implemented, managers make decisions on how it is run. In this world, as we saw in Part II, disclosure is important to efficient resource allocation in two

The proposition in the text would clearly hold if (i) the market for corporate equities was fully global along the price dimension, see supra Part I, and (ii) and $B$ 's economy was not a large portion of the total global economy. In this case, there would be one global-riskadjusted expected rate of return that would be unaffected by project return in $B$. The shares of country $B$ issuers such as $X$ and $Y$ would be priced to provide investors with that expected rate. The proposition will also hold under less stringent conditions. Consider, for example, a lack of perfect global integration due to a general reluctance among investors in $A$ to invest in foreign equities. The only condition needed for the proposition to hold would be that the value of the shares of country $B$ issuers being offered in $A$ does not form a substantial portion of the value of all the foreign equities that investors in $A$ are willing to consider. Even when this condition is not met, the likely reasons why it would not be met suggest that $A$ would not have the kind of stake that should give it the power to regulate the disclosure practices of these $B$ issuers. One possible reason that shares of $B$ issuers could form a substantial portion of all the foreign investments that investors in $A$ would be willing to consider would be that $B$ 's economy constitutes a substantial portion of the whole global economy - for example, if $B$ were the United States. Then poorer project choice in $B$, through its effect on the supply of investment opportunities globally, would reduce the rate of return investors in every country expect on investments in the shares of foreign issuers. This would not, however, be a situation that forms a sound basis for giving $A$ the power to regulate the disclosure of $B$ issuers. $A$ residents have no more stake in the disclosure practices of $B$ issuers than have investors in all third countries.

A second possible reason that shares of $B$ issuers could form a substantial portion of all the foreign investments that investors in $A$ would be willing to consider would be that investors in $A$ feel significantly more comfortable with purchases of $B$ issuer shares than with the purchase of most other foreign issuer shares - for example, if $A$ were the United States and $B$ were Canada. This situation, however, suggests a situation of sufficiently intense interaction between these two particular economies that their regulation should, and as a practical matter can, best be handled by bilateral agreements between the two countries establishing a joint regime, rather than general rules parceling out authority between the two countries as to which national regime should govern. The United States and Canada are working toward such an arrangement by undertaking a degree of coordination of their two regimes and then providing for reciprocal recognition for qualified issuers that register under the other country's regime. See Multijurisdictional Disclosure and Modifications to the Current Registration and Reporting System for Canadian Issuers, Exchange Act Release No. 33,6902, 56 Fed. Reg. 30,036 (1991). 
ways. First, just as in the simplified world, in cases in which firms finance their projects through the public sale of shares, less accurate prices lead to an inferior choice of projects to be implemented. Second, once firms have their initial injections of publicly held equity, self-interest may lead their managers, when making both project choice and operating decisions, to deviate from what is in the existing shareholders' best interests. The market for corporate control and share-price-based compensation schemes help to limit deviations, but, as we saw in Part II, the effectiveness of these mechanisms depends on the ongoing level of available information and share-price accuracy over the rest of the life of the firm. Resource allocation efficiency thus depends both on the level of disclosure at the time that firms sell shares to the public and on the ongoing level of firm disclosure thereafter.

(a) Initial Public Offering Disclosure. A has no resource allocation or cost-based stake in the level of $B$ issuer disclosure at the time of initial public offering. The analysis here directly parallels the analysis in the simplified world. Suppose that $B$ issuers do not disclose very much. Less disclosure means less share-price accuracy and hence more misallocations and a lower expected cash return. Again, this will not affect investors in $A$. The prices of $B$-issuer shares will be discounted to reflect this lower expected cash return, guaranteeing that $A$ investors will get the same expected rate of return despite the lower level of disclosure. Entrepreneurs in $B$ bear the discount, because a lower offering price will result in greater dilution of their holdings, ${ }^{107}$ and they are the ones who would enjoy the cost savings.

(b) Ongoing Periodic Disclosure. In one sense, the same can be said of $A$ 's resource allocation and cost-based stakes in the ongoing periodic disclosure practices of $B$ issuers. At the time that an issuer from $B$ offers its shares to investors in $A$, the investors have an expectation concerning the firm's level of ongoing disclosure in the future. They thus have an expectation concerning the effectiveness with which, over the rest of the issuer's life, the market for corporate control and share-price-based compensation schemes will

107. The empirical literature supporting information asymmetry explanations of the discount of IPO offering prices relative to their initial trading prices, see supra note 78, suggests that the less that is known about an issuer, the greater the discount. See, e.g., Ibbotson et al., supra note 78, at 41-42; Ritter, supra note 78, at 222-31, 237. This literature thus also tends to support the proposition that entrepreneurs bear the cost of suboptimal levels of disclosure. 
limit managerial deviations from optimal project choice and operating decisions.

An expectation of less disclosure, for example, will lead to an expectation of greater deviations, and a resulting smaller cash flow available to shareholders. The offering price of the issuer's shares will be discounted to reflect this smaller expected available cash flow. The expectation of accompanying cost savings would affect the offering price in the opposite direction. Investors in $A$ thus again will receive the same expected rate of return, regardless of $B$ issuers' expected level of ongoing disclosure over time, and entrepreneurs in $B$ will bear the effects of the expected disclosure practices of $B$ issuers.

In a second sense, however, $A$ 's allocation efficiency and costbased stakes in the ongoing disclosure practices of $B$ issuers are real and quite different from its stakes in initial public issue disclosure. From the point of an initial public offering by a $B$ issuer onward, $A$ residents hold all of its publicly traded shares. For these $A$ shareholders, the optimal level of disclosure is the one whereby the issuer discloses just up to the point where the marginal costs of any additional disclosure would start to exceed the resulting further marginal reduction in managerial deviations. $A$ shareholders are worse off to the extent that disclosure is not at this level. ${ }^{108}$ The ongoing interest of the $A$ shareholders in the issuer adhering to this optimal level of disclosure does not perfectly coincide with the ongoing interest of the managers, who are residents of $B$. Even if the managers are the issuer's founding entrepreneurs, or are otherwise significant shareholders, their gains from the managerial deviations permitted by a suboptimal level of disclosure may be greater than their losses as holders of only part of the issuer's shares.

(c) Subsequent Public Offering Disclosure. An analysis of $A$ 's resource allocation and cost-based stakes in the level of disclosure at public offerings subsequent to initial offerings requires identifying the multiple functions played by such disclosure. One function for subsequent public-offering disclosure is the same as for initial public-offering disclosure: to guide funds to the firms that can make the best use of them. $A$ now needs to be concerned about two groups with regard to this function: the new investors from $A$ who are considering the offering and the issuer's existing $A$ shareholders. The level of disclosure required of $B$ issuers does not af-

108. To the extent that it was expected that the disclosure level was not going to be optimal, the $A$ investors are, of course, compensated in advance by a discounted purchase price. 
fect the new investors from $A$. Again, less disclosure means less price accuracy and hence more cases of funds going to firms that are not the ones that can make the best use of them. Again, the share prices of $B$ issuers engaging in these public offerings will be discounted to reflect this fact. So, as with the initial public offering, the new investors from $A$ will get the same level of return regardless of the level of disclosure. Now, however, this discount and the costs of disclosure are borne by the existing shareholders from $A$ as well as the entrepreneurs from $B$. A lower offering price will result in a greater dilution of the holdings of both. This effect of the disclosure level on the existing $A$ shareholders, however, does not form the kind of stake in the subsequent public offering disclosure practices of $B$ issuers that, by itself, is likely to generate a desire by $A$ to regulate those practices. This is because the interests of the $A$ investors exactly parallel the interests of entrepreneurs in $B$.

The second function served by subsequent public-offering disclosure is the same as that of ongoing disclosure: to assist in the functioning of the market for corporate control and share-pricebased compensation schemes to limit managerial deviations from optimal project choice and operating decisions. ${ }^{109}$ With regard to this function, $A$ 's stakes are real. The existing $A$ shareholders have the same interests in the $B$ issuer's subsequent public offering disclosure as they do in their periodic disclosure practices. As in ongoing disclosure, these interests do not perfectly coincide with those of the issuers' managers who are from $B$.

\section{The Stakes for B, the Country of the Issuer}

Now let us consider the consequences to country $B$ if firms such as $X$ and $Y$ reveal less rather than more about themselves. Investor fairness and risk are not concerns, because of our assumption that these firms have no $B$ residents among their public shareholders. Our concern instead exclusively focuses on country $B$ 's stakes in the allocation-of-resources effects of issuer disclosure and its costs.

a. Entrepreneurs. From the discussion immediately above, we already know a great deal about the distribution of disclosure's resource-allocation benefits and costs. In the simplified world of only initially capitalizing firms, we saw that the level of disclosure

109. The suggestion that subsequent public-offering disclosure regulation can have this second, agency-cost-reducing function is not new. See Fox, supra note 25, at 138-39, 339-67; Frank H. Easterbrook, Two Agency-Cost Explanations of Dividends, 74 AM. Econ. Rev. 650 (1984); Fox, supra note 69, at 1018-22. 
determines the proportion of superior to inferior projects chosen to be implemented and the consequent expected cash return. Entrepreneurs in $B$ fully bear this effect on expected cash return and on the costs of disclosure. In the more complex world where issuers have an ongoing existence, the level of ongoing disclosure expected at the time of an issuer's public offering creates expectations concerning the level of managerial deviations and disclosure costs and hence the level of cash flow available to shareholders. As the market price discounts for this, entrepreneurs fully bear the effects. Thereafter, however, if an issuer discloses at less than an optimal level, its entrepreneurs only feel part of the effect on the firm's net cash flow. They no longer own all the equity; the firm's shareholders in $A$ bear the remainder of the effects. If these entrepreneurs continue in a managerial capacity, they can enjoy all of the benefits from the managerial deviations permitted by the suboptimal disclosure.

b. Labor. We have not yet considered the other group that can be affected by the choice as to which investment projects are implemented and how they are operated - the suppliers of the other factors of production, most importantly, labor. For the projects of $B$ issuers, these suppliers will be concentrated in $B$. The analysis below shows that they too are almost certain to be beneficiaries of the improved allocation of resources that results from both greater new public issue disclosure and greater ongoing disclosure. This is a very important conclusion because it underscores the importance of country $B$ 's stake in the disclosure practices of its issuers, even in the artificially extreme case of issuers whose public shares are offered to, and traded by, investors residing in country $A$ exclusively. This conclusion will be demonstrated in terms of the effects of greater new public issue disclosure on project choice in the simplified world of initially capitalizing firms. The reasoning is equally applicable, however, to the effect of ongoing disclosure on the way that the market for corporate control and share-pricebased compensation disciplines managers of ongoing firms in their project choice and operating decisions. ${ }^{110}$

i. Labor's Absolute Share and the Technical Change Analogy. Analyzing the effect of the quality of project choice on labor in $B$ is a complex task. The analysis requires us to determine what would happen to labor's absolute share of $B$ 's national product if issuers

110. See infra note 119. 
such as $X$ and $Y$ disclosed more. Does labor gain or lose from the better allocation of capital that results from improved share-price accuracy?

In a competitive economy, each unit of labor is paid the value of the marginal physical product of labor $(\mathrm{mppl})$ - the value of the increased output resulting from the addition of the marginal unit of labor. ${ }^{111}$ Labor's absolute share of $B$ 's national product consequently equals the total number of units of labor, $L$, multiplied by $m p p l$. Assuming that $L$ stays constant, the effect of better allocation on labor's absolute share of $B$ 's national product depends on the effect of better allocation on labor's marginal physical product.

To get a feel of the effect of better allocation on the demand for labor, consider first the single reallocation from $X$ 's project to $Y$ 's project, which by itself would be too insignificant within the workings of $B$ 's whole economy to have a perceptible effect on the price of labor or its availability to other projects. By definition, Y's higher expected cash return means that the spread between the value of output and the cost of inputs for $Y$ 's project exceeds that for $X$ 's project. Assuming constant returns to scale, this greater spread can only be explained by one or more of the following three things being true of $Y$ 's and $X$ 's production functions: ${ }^{112}$ (i) $Y$, us-

111. In models of an economy of this sort, each unit of labor is typically assumed to be interchangeable with each other unit. In other words, there is no recognition that workers differ in their skills and effort. In equilibrium, the value of $m p p l$ is equal across all industries.

112. A firm's production function states the maximum output that the firm can obtain for each possible combination of capital and labor. The two projects have different production functions because the managers possess different technical information about how to transform the inputs into output or, in this particular model, because the managers, for reasons other than profit maximization, constrain themselves from utilizing a method of transformation about which they do possess the technical information. Thus, somewhat unusually, the issues of competency or skill on the one hand and nonprofit-maximizing managerial behavior on the other are, in this part of the discussion, collapsed into the firm's production function. With the production function so stated, firms are assumed to seek to maximize profits.

This treatment of agency costs bears a resemblance to the approach of Jensen and Meckling. See Jensen \& Meckling, supra note 95 . One of their cardinal contributions was to reintegrate important observations of the managerial theory of the firm into the larger neoclassical framework of profit maximization. They saw that there were economic advantages to the separation of ownership from control - i.e., having finance and risk bearing provided by passive investors and managerial skills provided by professional manajers - but that there were costs as well - both the costs to shareholders of managerial deviations from maximizing shareholder value and the costs of combating this behavior. Maximizing economic welfare means minimizing these total costs rather than the impossible task of eliminating managerial deviations entirely.

To isolate out the effects of disclosure on the quality of project choice, I am in essence treating the agency costs of a given issuer as fixed. The same kind of analysis also can show that the effects of ongoing disclosure on the disciplining mechanisms of the market for corporate control and share-price-based compensation will also very likely lead to an increase in labor's absolute share of $B$ 's national income. Greater discipline increases the expected cash returns of all firms. Again, it can only do so by changing the firms' production functions in one or more of the three ways listed in the text. 
ing the same amount of each input as would $X$, can produce an output that sells for more than that of $X$; (ii) $Y$ can produce an output of the same value as that of $X$ using the same amount of labor as would $X$ but less capital; or (iii) $Y$ can produce an output of the same value as that of $X$ using the same amount of capital as $X$ but less labor.

Stated this way, one can see a close analogy between better capital allocation and technical change. Each describes a phenomenon by which an economy produces a more valuable output from a given fixed set of inputs. The difference is that the study of technical change starts out with all the economy's firms having one set of production functions and looks at the effects of a change in those production functions as a result of new technical knowledge. It assumes the occurrence of the appropriate welfare-maximizing input reallocations in response to these changes in production functions. In contrast, the study of better allocation assumes that a variety of firms already exist, each possessing its own production function and the change involves one set of firms receiving capital instead of another. What the phenomena of technical change and better capital allocation share in common is that the firms that are receiving capital after the change have different production functions than the firms receiving capital before the change and economic welfare is enhanced as a result. The analogy between technical change and reallocation is important because the effect of technical change on labor's share of national income has been the subject of considerable study by economists. ${ }^{113}$

To employ this analogy to trace the effect of better capital allocation on labor's share, we will begin with the assumption, subsequently to be relaxed, that all firms in the economy produce the same product. We will also assume that the level of disclosure by $B$ issuers does not affect the aggregate amount of capital flowing from $A$ to $B$, just to which firms it goes. ${ }^{114}$

113. See, e.g., J.R. Hicks, The TheORY of WAGES 89-135 (1963); K.J. Arrow et al., Capital-Labor Substitution and Economic Efficiency, 43 REv. Econ. \& STAT. 225, 244-246 (1961); Irving B. Kravis, Relative Income Shares in Fact and Theory, 49 AM. ECON. Rev. 917 (1959).

114. This second assumption helps segment the analysis into tractable parts and, though inaccurate, is harmless. It is inaccurate because it ignores the effects of poorer disclosure (when not cost justified) on the demand in $B$ for capital from $A$. As explained above, see supra note 104, the expectation of lower project cash return will diminish the returns to entrepreneurs and hence diminish the amount of capital being demanded. The assumption is harmless because the larger amount of capital flowing from $A$ to $B$ when $B$ 's issuers increase disclosure will by itself increase the $\mathrm{mppl}$ in $B$ and hence simply supplement the increase in $m p p l$ from better allocation that the analysis in the text suggests is likely. 


\section{ii. All Firms Produce the Same Product - Neutral Impact on} Factor Effectiveness. The first explanation of $Y$ 's greater expected cash return, where both projects would use the same amounts of labor and capital but the value of $Y$ 's output would be greater than $X$ 's, can be analogized to factor-neutral process innovation. Using the factors in $Y$ is equivalent to using in $X$ a proportionally larger number of units of each factor. It is as though their use in $Y$ proportionally increases the number of "effective" units of each factor. Suppose for a moment that the differences in expected cash return among all proposed projects seeking foreign capital is due to this first cause. What would be the effect of greater disclosure by the $B$ issuers seeking capital in $A$, so that more of the better projects like $Y$ and fewer of the worse projects like $X$ are chosen? If the production functions involved conform to standard assumptions, the marginal products of labor and of capital will each grow proportionally. ${ }^{115}$ Labor and capital divide in the same proportions a larger pie so that labor's absolute share of national product increases.

iii. Same Product - Capital-Saving Impact. The second explanation of $Y$ 's higher expected cash return, that $Y$ has a production function that permits it to produce the same amount of output as $X$ using the same amount of labor but less capital, can be analogized to capital-saving process innovation. Using a given amount of capital in $Y$ is equivalent to using a larger number of units of capital in $X$. It is like increasing the number of "effective" units of capital.

115. $X$ 's production function can be stated as $Q_{x}=X(L, K)$, where $Q_{x}$ is $X$ 's output and $L_{x}$ and $K_{x}$ are the inputs of labor and capital, respectively. $Y$ 's production function can be stated as $Q_{y}=Y(L, K)$, with $Q_{y}, L_{y}$, and $K_{y}$ having parallel meanings. According to the description of the production functions in the text, $Q_{y}=X(k L, k K)$ (where $k$ is a constant greater than 1). Because of the assumption of constant returns to scale, $Q_{y}$ also equals $k X(L, K)$. Thus $d Q_{y} / d L=k d Q_{x} / d L$ and $d Q_{y} / d K=k d Q_{x} / d K$.

Assume for a moment a "pure case" in which all capital comes from abroad, high issuer disclosure means that all $Y$-type projects and no $X$-type projects will be implemented, and low issuer disclosure means the opposite. The total amount of capital and labor is fixed, and thus, if capital goes to the $Y$ projects instead of the $X$ projects, each $Y$ project would receive the same amount of each input as the $X$ projects otherwise would have. Thus, with better allocation, the mppl and mppk would each be just $k$ times their values with worse allocation.

It is more realistic to assume that only some of $B$ 's firms seek capital from abroad and that more disclosure by these firms only results in the implementation of some $Y$ projects instead of $X$ ones. As long as the proposed projects seeking foreign capital are representative of the economy as a whole in terms of their factor intensities, the mppl will with more disclosure still increase in competitive equilibrium, but not by a factor of $k$. This is because if only as much labor was used in the $Y$ projects as would have been used in the $X$ projects, the $m p p l$ in the $Y$ projects would be greater than the mppl in all the other projects and hence greater than the wage rate. Thus, the $Y$ project managers would seek more labor, lowering their $\mathrm{mppls}$ and raising those of all other projects to a point where the mppls in the $Y$ projects and in the others would all be equal. 
Now suppose for a moment that the differences in expected cash return among all proposed projects seeking foreign capital are due to this second cause. What, this time, would be the effect of more disclosure by the $B$ issuers seeking capital in $A$ so that more of the better projects like $Y$ and fewer of the worse projects like $X$ are chosen? If the production functions involved conform to standard assumptions, the marginal product of labor would increase. ${ }^{116}$ This is because the number of units of labor stays fixed, but the number of effective units of capital increases, thereby giving each unit of labor more effective capital to work with. Labor's absolute share, the total amount of labor times its marginal physical product, would thus again increase.

iv. Same Product - Labor-Saving Impact. The third explanation of $Y$ 's higher expected cash return, $Y$ having a production function that would permit it to produce the same amount of output as $X$ using the same amount of capital but less labor, can be analogized to labor-saving process innovation. Using a given amount of labor in $Y$ is equivalent to using a larger number of units of labor in $X$; it is as though the number of "effective" units of labor increased. Momentarily assume that the differences in expected cash return among all proposed projects seeking foreign capital are due to this third cause. What now would be the effect of more disclosure by $B$ 's issuers so that more of the better projects like $Y$ are chosen and fewer of the worse projects like $X$ ? This time, there is no unambiguous answer to derive from standard assumptions about production functions generally. The answer instead depends on their more specific characteristics.

116. $X$ 's and $Y$ 's production functions can be as stated in supra note 115 . According to the description of the production functions in the text, $Q_{y}=X\left(L, E_{k} K\right)$, where $E_{k}$ is a constant greater than 1. Adopting the common assumption that both production functions are linear homogenous - the isoquants all have the same shape and there are constant returns to scale - it can be shown that $d Q_{x} / d L d K$ will then be positive. That is, for any given amount of labor, $m m p l$ increases as $K$ increases. See Henderson \& QuANDT, supra note 99, at 79-85. Thus $d Q_{y} / d L$ will exceed $d Q_{x} / d L$ for any given actual amounts of capital and labor allocated to a firm utilizing one production function or the other.

Assume first a "pure case" in which all capital comes from abroad, and assume that high issuer disclosure means that all $Y$-type projects and no $X$-type projects will be implemented and low issuer disclosure means the opposite. Again, with the total amount of capital and labor fixed, each $Y$ project would with high disclosure receive the same amount of each input as each $X$ project otherwise would have. Under these circumstances, as discussed in the paragraph above, the $m p p l$ will be greater.

Now, more realistically, assume that only some of $B$ 's firms seek capital from abroad and that more disclosure by these firms only results in the implementation of some $Y$ projects instead of $X$ ones. For the same reasons as with the explanation analogized to factor-neutral technical change, the mppl will still be greater but not by as much as in the "pure case." See supra note 115 . 
Two contradictory forces are at work in this case, each a result of the fact that one actual unit of labor stands for more than one effective unit. On the one hand, for any given total number of actual units of labor used in $Y$, a greater number of effective units are being used. Reflecting the law of diminishing returns, the marginal product of an additional effective unit thus will be lower. On the other hand, one more actual unit of labor used in $Y$, when added to any given number of effective units of labor, will add more to output than will adding one more effective unit. Given a fixed number of actual units of labor, whether the second force dominates the first depends on the ease with which labor and capital can be substituted for each other in $X$ 's production function - that is, the elasticity of substitution between labor and capital. ${ }^{117}$ The greater the ease of substitution, the less that an increase in the aggregate number of effective units of labor drives down the product of the marginal effective unit of labor and hence the less important the first force.

Empirical study of the U.S. economy strongly suggests that this second force in fact does dominate. As set out in the Appendix, the U.S. economy's production functions display an ease of substitution such that better allocation would increase the marginal product of an actual unit of labor. Hence labor's absolute share of national product would increase, even under the highly artificial assumption that differences in expected cash return among all proposed projects seeking foreign capital are due solely to this third explanation. The same is likely to be true of other developed countries as well.

v. Same Product - the Likely Balance of Impacts. The probability that better allocation would increase $B$ 's $m p p l$ is even greater if differences between the projects that receive capital with better allocation and those that receive it with worse allocation are, as in the real world, due, to one extent or another, to all three explanations. The most plausible assumption about the mix of these projects is that it will show no overall bias toward capital saving or labor saving projects. ${ }^{118}$ In that event, even if, despite the contrary

117. See Appendix.

118. The reason why $X$-type projects rather than $Y$-type projects are more likely to be chosen with less disclosure is greater ignorance. Assuming that among all the projects proposed, there is no labor-saving bias in the reasons why the better projects are better, plain ignorance should not result in missing more $Y$ projects that were superior to the $X$ ones because of their labor-saving potential than $Y$ projects that were superior to $X$ ones because of their capital-saving potential. 
indications of the empirical studies, the elasticity of substitution is sufficiently low that labor-saving better allocations alone would lower the mppl, their effect would be more than canceled out by the equal number of capital-saving better allocations. ${ }^{119}$ Factor-neutral better allocations, which enhance the marginal products of both factors, would simply add to the improvement in labor's marginal product.

\section{vi. Firms Produce Different Products - the Likely Balance of} Impacts. Relaxing the assumption that the economy produces only one product should not alter the general conclusion that better capital allocation will enhance labor's absolute share of national income. This is obvious where Y's production function, despite involving a different product, bears a linear relationship to that of $X$. For every given combination of labor and capital, the amount of $Y$ product that would be produced will be the same multiple of the

An assumption of no bias seems plausible: each entrepreneur had every incentive to have its firm have the most productive production function possible, one that for each possible amount of labor requires the least capital for any given output and vice versa. The proponents of the $X$-type firms simply have not done as well in pursuing this goal. There is no reason why, when they fall short, they are more likely to miss opportunities to save labor than capital.

It is true that innovation is a major spur for proposing new investment projects and that economists generally believe that there is a labor-saving bias to innovation. See, e.g., Hicks, supra note 113, at 123-24; Kravis, supra note 113, at 941-42. But this does not necessarily undermine the plausibility of the neutrality assumption: more of both the $X$-type and $Y$-type projects might be spurred by labor-saving ideas than capital-saving ideas, but the difference between them might reflect a balance of missed opportunities to save inputs. Even if this does not hold true, however, it is important to note that a substantial portion of all proposed projects, $X$-type and $Y$-type, will be spurred by the need to replace existing capacity, to meet new demand, or to provide new products, rather than by the potential of new input-saving production innovation.

119. Assuming, as we have, linear homogeneous production functions, the marginal products depend only on the ratio of the inputs. A better allocation that saves a given proportion of the economy's total amount of capital clearly increases the marginal product of an actual unit of labor by giving each unit of labor more effective units of capital with which to work. A better allocation that saves the same proportion of the economy's total amount of labor has two opposing effects on the marginal product of an actual unit of labor. First, it decreases the marginal product of labor by the same amount as the capital-saving better allocation increases it because the increase in the effective number of units of labor decreases the amount of capital available to each effective unit of labor by the same amount that the capital-saving better allocation increases the amount of capital available to each unit of labor. Second, the labor-saving better allocation raises the marginal product of labor because each actual unit now stands for more than one effective unit of labor. If the elasticity of substitution is much lower than the empirical studies indicate, the first effect would dominate the second and labor-saving better allocations would lower mppl. However, with an equal number of $Y$ projects being capital saving and labor saving, an increase in the adoption rate of $Y$ projects will still increase $\mathrm{mppl}$ : the increase in $\mathrm{mppl}$ from the capital-saving projects would just cancel out the decrease from the first effect of the labor-saving projects, leaving the second effect to raise $\mathrm{mppl}$. 
amount of $X$ product that would be produced. ${ }^{120}$ If one combination of inputs produces 100 units of $X$ 's product and 150 units of $Y$ 's product and another combination would produce 200 units of $X$ 's product, that second combination thus would produce 300 units of $Y$ 's product. What makes $Y$ 's project superior is that for each of the given combinations of inputs, $Y$ 's output sells for more than $X$ 's output. In this situation, allocation of capital to $Y$ instead of $X$ is again analogous to factor-neutral process innovation. Using any given combination of inputs in $Y$ is equivalent, in terms of the value of the output, to using a proportionally greater number of units of each factor in $X$. Again, in terms of value produced, it is as though their use in $Y$ proportionally increases the number of effective units of each factor. Analogous to the reasoning above, if the differences between the $Y$-type projects and $X$-type projects were all of this kind and more disclosure by $B$ issuers seeking capital in $A$ would lead to more $Y$ projects and fewer $X$ projects, the marginal products of labor and of capital will each grow proportionally. ${ }^{121}$ Obviously, in reality the production function of $Y$ will not bear a linear relationship to that of $X$. But the assumption that it does is adequate for looking at aggregate consequences of better allocation.

Relaxing the single-product assumption introduces the issue of consumer preference among products. Considering consumer preference among products creates the possibility that a $Y$ project will be superior to an $X$ one because, at the margin and given the prices of inputs reflecting their opportunity costs, $Y$-project proponents are better able to sense consumer preferences. There is no reason to believe that the products that the proponents of such $Y$ projects choose would on average be more or less labor intensive than the products that the proponents of the $X$ projects would choose. Both groups of proponents are competing for funds and both are trying their best to gauge consumer preferences. The only difference is that the $Y$ proponents are more successful at it.

Like factor-neutral process innovation, the aggregate effect of product innovation thus should be to increase labor's marginal product and hence its absolute share of national income.

120. In more technical terms, the production functions of $X$ and $Y$ differ only by a scalar. If $Q_{x}(L, K)$ is the production function for $X$, and $Q_{y}(L, K)$ is the production function of $Y$, then $Q_{x}(L, K)=k Q_{y}(L, K)$, where $k$ is a constant positive real number. Given our continuing assumption that they are homogeneous, all the isoquants of both production functions will be the same shape. Thus, while $X$ and $Y$ would produce different products, their respective production functions are such that, given the market prices of labor and capital, the managers of each will use capital and labor in the same proportions. See Henderson \& Quandr, supra note 99 , at $79-81$.

121. See supra note 115 and accompanying text. 


\section{The Relevance of the Place in Which the Transaction Is Executed}

The last dimension of nationality - the place the transaction is effected - has not played a role in this analysis of standard transactions. It is the central focus of the discussion of transplant transactions that follows where place is the unique factor that makes the transactions transnational. The relevance of place to the stakes of the two countries in standard-transaction disclosure will be postponed until the discussion of issuer-country transactions, because the place of the transaction is the sole factor that distinguishes standard transactions from issuer-country transactions. Its relevance thus is most easily seen through a comparison of the stakes of the two countries in the two kinds of transactions.

\section{B. The Transplant Transaction: Buyer From B; Issuer From B; Transaction Occurs in A}

In the "transplant" transnational transaction, the issuer and the investor buying or selling the security are of the same country. It is essentially a domestic transaction except for the fact that it is effected in the securities market of another country. Transplant transactions have historically been rare for a large, developed country such as the United States. Investors want to minimize transaction costs by engaging in transactions in their home countries and issuers will tend to promote a market for their securities first domestically, where there would naturally tend to be the largest interest in them. Other forces related to differences between countries in their mandatory disclosure regimes or the execution efficiency of their exchanges, however, may create incentives for such issuers to promote transplant transactions. With the cost differential between effecting a transaction on a foreign market and on a domestic market declining, transplant transactions are likely to become more important in the future.

Remember again that we are assuming an extreme set of facts in which the shares of the issuers on which we focus will only be sold and traded in transplant transactions. There are no public sales to or trades among residents of $A$ in the shares of these issuers, nor are there any sales or trades effected in $B$.

\section{The Different Nature of the Stakes}

In a transplant transaction, all the benefits and costs from disclosure discussed so far are experienced exclusively by residents of 
$B$. They are the investors, the entrepreneurs, and the suppliers of the other factors of production. They are the ones who enjoy the risk reduction and better allocation resulting from increased disclosure and who bear its added costs, however these benefits and costs are distributed among them. The situation is no different than if the initial offering and subsequent trading in the shares were entirely domestic. In terms of these interests, $B$ is the only country that has a stake in the disclosure practices of its transplant-transaction issuers. Even though transactions in their shares are being effected in $A$, $A$ has no stake.

There is another interest that we have not yet considered: the volume of securities transactions effected within a country's borders. Serving as the location for securities transactions economically benefits the residents who provide the services necessary to effect these transactions. If the level of disclosure that accompanies transplant transactions in $A$ differs from that which accompanies domestic transactions in $B$, the difference can affect the quantity of these transplant transactions and hence the total volume of securities transactions effected in each country. $A$ has an interest in the existence of a difference if the difference is one that would increase country $B$ issuer-transplant transactions. Because most transplant transactions likely are substitutes for purely domestic transactions, $B$ would have a volume-related countervailing interest of similar strength in removing any difference - that is, in place being irrelevant to the level of disclosure by $B$ issuers.

The likely source of any difference between the disclosure that accompanies transplant transactions and that which accompanies purely domestic ones would be a difference in the rigor of each country's mandatory disclosure regime. The stakes of countries $A$ and $B$ in the transplant transaction disclosure of $B$ issuers thus translate into their respective stakes in whether or not the application of $A$ 's regime to such transactions substitutes for the application of $B$ 's regime.

\section{Country A's Regime Is the More Rigorous: The Market Reputation and Cost Deterrence Effects}

a. The Market-Reputation Effect. Suppose that $A$ 's disclosure regime, at least when applied to its purely domestic transactions, is more rigorous than $B$ 's. Thus, $A$ might be the United States, and $B$ might be Germany. If $A$ applies the same regime to transplant transactions, issuers from $B$ that promote transplant transactions in 
$A$ will have to disclose more than if they promote purely domestic transactions.

This difference can attract certain transactions to $A$. Consistent application of $A$ 's regime creates a reputation that any issuer whose shares are sold or traded in $A$ has disclosure practices that meet $A$ 's higher standard. Given such a reputation, the mere fact that an issuer's shares are sold or traded in $A$ economically communicates to investors that the issuer, even if it is from $B$, meets $A$ 's standards. An issuer would want to make such a communication if it determines that the benefits of meeting this higher standard exceed the costs. An issuer making such a determination has an incentive to promote the public sale or trading of its securities in $A$. In order to establish or preserve the reputation that creates this incentive, $A$ has a stake in the issuer actually meeting the standard.

If $A$ 's regime is the more rigorous and market reputation is the only factor that draws transplant transactions to $A, A$ has a stake in $B$ issuers disclosing more when transactions in their shares occur within $A$ 's borders than when they occur at home in $B$. $A$ wants location to matter and wants to apply its regime. $B$ has a countervailing volume-related interest in removing any difference, so that location does not matter. ${ }^{122}$

b. Other Attractions to $A$ and the Cost-Deterrence Effect. Some issuers in $B$, however, may have reasons other than $A$ 's reputation for high disclosure standards to promote transplant transactions. For example, $A$ may have a stock market that executes transactions more efficiently than do the markets in $B$. If this is the case, it becomes ambiguous whether $A$ has a volume-related stake in the existence of a disclosure difference for transplant-transaction $B$ issuers. One group of $B$ issuers is, as just described, attracted by the difference and without it would not promote transplant transactions in their shares even given $A$ 's superior execution efficiency. Another group of $B$ issuers, however, might find $A$ 's execution efficiency, if that were all that was involved, to be a sufficient inducement to promote transplant transactions of their shares in $A$, but might find that the costs of complying with $A$ 's regime exceed the

122. Of course, other considerations, unrelated to volume, may point in the opposite direction. Suppose that some $B$ issuers that find the benefits of meeting $A$ 's standards exceed the costs are correct in terms of social benefits exceeding social costs. Because all the entrepreneurs, investors, and suppliers of other factors of production associated with these issuers are $B$ residents, it is $B$ 's residents who gain if the issuers can find a mechanism to assure investors that they in fact will meet these higher standards. If $B$ 's government is unable to provide such a mechanism and views these gains to its residents as outweighing the negative effect on share transaction volume in $B$, it would on balance favor application by $A$. 
benefits by such an amount that they would decide not to come to $A$. The second group is likely to be larger than the first because the managers of most $B$ issuers would probably prefer not to disclose at $B$ 's required level, let alone $A$ 's. ${ }^{123}$

When these additional considerations are added in, $A$ 's more rigorous standard may lead it to want the place of the transaction not to matter in how much a $B$ issuer discloses. $A$ would not have a stake in transplant-transaction $B$ issuers disclosing more than domestic-transaction $B$ issuers unless the number of transactions drawn in by reputation exceeds the number deterred by the costs of disclosure. $B$ would have exactly the opposite volume-related stakes. $B$ would want location to matter unless the marketreputation effect outweighed the cost-deterrence effect.

\section{Country B's Regime Is the More Rigorous: The Regulatory- Evasion Effect}

Suppose instead that $A$ 's domestic disclosure regime is less rigorous than $B$ 's. Thus, $A$ might be the United Kingdom, and $B$ might be Canada. If $A$ applies its regime to transplant transactions in $B$ issuer shares and this results in $B$ 's regime not being applied to these issuers, $B$ issuers will not have to disclose as much in transplant transactions as they would have to disclose in domestic transactions. This difference too will attract certain transactions to $A$. For some entrepreneurs and managers in $B$, the costs of meeting $B$ 's disclosure standards exceed the benefits to them. They will

123. $B$ issuer managers decide where their shares are traded and offered. For most of them, the costs of complying even with $B$ 's regime likely exceed the reputational benefit of doing so. Absent regulation, an issuer voluntarily chooses to disclose at the level where the reputational benefits in the market from disclosing at that level just equal the costs as perceived by management. As we saw in Part II, supra, strong theoretical reasons exist for believing that the level so chosen is lower than the level that is socially optimal. The cost of disclosure in the manager's eyes includes harm to the issuer resulting from information given to competitors, major suppliers, and customers. This harm, however, is not a social cost of disclosure, because these recipients of the information enjoy commensurate benefits.

Assuming that $B$ 's required disclosure level is not set below $B$ 's social optimum level from a risk reduction and resource allocation efficiency point of view, most $B$ issuers thus would prefer to disclose less than that and would certainly not be attracted to $A$ 's even stricter regime. This is an appropriate assumption. Admittedly, political structures within some countries, particularly developing ones, may result in disclosure standards below the social optimum. However, where, as here, the issue under study is regulation with respect to behavior with cross-border effects, it is conventional to assume, as a reasonable first approximation of reality, that the countries involved act in their own best interests when regulating entirely domestic versions of the same behaviors. This, for example, is a fundamental assumption behind the governmental-interest method for identifying "true conflicts" of law. See William F. Baxter, Choice of Law and the Federal System, 16 Stan. L. Rev. 1 (1963); Larry Kramer, Rethinking Choice of Law, 90 Colum. L. Rev. 277 (1990). 
have an incentive to promote transplant transactions in place of domestic ones.

This time, however, the existence of other reasons for $B$ issuers to be attracted to $A$, such as execution efficiency, will not cut significantly against $A$ 's preference for the difference. Some of the issuers attracted by such other reasons might well be concerned with $B$ 's lesser-market reputation, but this concern is unlikely to deter them from promoting transplant transactions in $A$. As $B$ issuers, they presumably can choose not to opt out of $B$ 's regime, even if all selling and trading of their shares occur in $A$. This would communicate to investors that the issuer, despite being sold and traded in $A$, will comply with $B$ 's higher disclosure standards. ${ }^{124}$ The regulatory evasion effect will dominate the reputation effect. When $A$ 's regime is the less rigorous, therefore, $A$ has a clear volume-related stake in transplant-transaction $B$ issuers not disclosing as much as they would need to if the transactions were effected at home. $B$ has the same clear countervailing volume related stake in the issuer disclosing the larger amount of information required by its regime even though the place of the transaction is abroad. $A$ wants the level of disclosure to depend on location; $B$ does not.

\section{Increased Investor Willingness to Trade on a Country's Market Is Not a Sound Basis for Imposing Its Regime on Transplant Transactions}

This analysis focuses on the decisions of $B$ issuers as to where to promote the sale or trading of their shares and not on the decisions of investors. This is because the financial economics models employed in this analysis suggest that a country's reputation concerning the disclosure practices of issuers whose shares are sold or traded within its borders will not affect investor willingness to trade

124. Two objections might be raised here. First, unlike the fact that $A$ is the place where a particular $B$ issuer's shares are being sold or traded, the fact that the issuer nevertheless chooses to register its securities in $B$ when it does not need to will not be known to all investors. Not all investors will know that the issuer is in effect voluntarily binding itself to conform to $B$ 's higher standard. But not all investors need to know of the issuer's registration in $B$ for the price to reflect that fact. It is the price effect of the disclosure choice that attracts the issuer to register its securities in the first place.

Second, and somewhat more serious, if $B$ 's regime is not automatically applied to transplant issuers from $B$, the issuer that originally announces it will nevertheless comply with $B$ 's regime could presumably deregister at some later point. Registration in $B$ is not needed for continued trading of the issuer's shares the way it would be if the issuer had gone public at home, and thus the issuer cannot provide investors with the same degree of assurance of continued high disclosure. To that extent, $B$ issuers with market-reputation concerns might stay home and avoid $A$ if $A$ 's regime applies to transplant transactions in substitution for $B$ 's regime. 
in that market one way or the other. If investors expect an issuer to provide less disclosure, they will expect that the cash returns from the issuer's projects will be lower because of poorer project choice and weaker managerial discipline. This results in a sufficiently lower share price to provide investors with an expected return equal to the competitive rate, but not in any reduced investor willingness to trade in the issuer's shares.

An important regulatory implication flows from this conclusion: When a country has the more rigorous disclosure regime, imposition of its regime on the basis that the transaction was effected within its territory can only be justified to the extent that such imposition attracts issuers of other countries voluntarily to promote such trading, not that it will make investors generally more willing to trade on the regulating country's markets. ${ }^{125}$

\section{Issuer-Country Transactions: Buyer From A; Issuer From B; Transaction Occurs in B}

\section{The Nature of Issuer-Country Transactions}

"Issuer-country" transnational transactions, like standard transactions, involve situations in which the buyer or seller of a security is of a different country than the issuer. Unlike the standard transaction, the transaction is effected in a securities market of the is-

125. An alternative story can be told that suggests that the reputations for disclosure of the issuers traded in a market could affect the general level of investor participation in that market. Under this story, investors perceive that securities about which little is known are likely to be unfairly priced. Many investors, for example, believe that insider trading results in unfairness and less extensive issuer disclosure increases the opportunities for insider trading. Investors may also believe that primary offerings by issuers about which little is known are likely to be at unfair prices. Even if, as most financial economists would argue, investors are wrong in these beliefs, the perception could lead some investors to be unwilling to buy and sell such shares at any price. Suppose that some investors do behave this way and that $A$ 's regime is the more rigorous but is not imposed on transplant transactions in shares of $B$ issuers. Then $A$ would have a stake in the disclosure level of these issuers. A lower level of investor participation in the market for these securities would reduce the volume of secondary trading occurring in $A$, and hence the demand for the services of $A$ 's securities industry.

Even if correct, however, this story does not make a compelling case for the imposition of country $A$ 's regime, rather than country $B$ 's regime, on $B$ issuers promoting transplant transactions in $A$. Country $B$ also has an additional stake, not previously considered, in the disclosure practices of its transplant-transaction issuers. Lower participation in the trading of the shares of such issuers will also hurt $B$ 's residents. $B$ 's investors would trade less, and the shares of $B$ 's issuers are involved. Reduced participation increases the aggregate amount of undiversifiable market risk in $B$ 's economy and reduces liquidity. Both effects result in a combination of higher capital costs and lower investor welfare, both of which are, in the case of transplant transactions, experienced exclusively by residents of country $B$. The effect of any reduced investor participation from lower disclosure by transplant transaction $B$ issuers, furthermore, should be limited to $B$ investors buying shares of $B$ issuers. It is unlikely that investors would be so unsophisticated as not to know that $A$ 's issuers must disclose more, particularly if securities industry participants were legally required to highlight the fact.

For an elaboration of these points, see Fox, supra note 68, at 274-77. 
suer's country. Like transplant transactions, issuer-country transnational transactions have historically been relatively unimportant. Effecting a securities transaction abroad has been significantly more costly and inconvenient to an investor than effecting a domestic securities transaction. This factor has generally kept the level of issuer-country transactions to a de minimis level - in terms of triggering disclosure regulations - for securities of most issuers, whether or not investors in any one or more other countries have a substantial interest in those securities. Where there is such substantial interest, the issuer will find worthwhile the set-up costs of promoting a market for its securities in the investors' home market. Any issuer-country transactions that would otherwise have occurred will then be displaced by cheaper standard transnational transactions. In the more typical situation in which no substantial interest among investors of another country existed, the issuer has not found the set-up costs worthwhile. The absence of a market in the investors' home country combined with the expense of effecting transactions abroad has meant that, although all transnational transactions in such an issuer's shares have been issuer-country transactions, there have been very few of them. With the cost differential between effecting a transaction on a foreign market and effecting one on a domestic market declining, and interest in investing in issuers abroad increasing issuer-country transactions, like transplant transactions, are likely, however, to become more important in the future.

In our examples of issuer-country transactions, the issuers are again nationals of country $B$. The sales and trades of their shares are to and among residents of $A$. All that differentiates these issuer-country transactions from standard transactions is that they are effected in country $B$ rather than in country $A$. Again, in order to focus our inquiry on the special issues raised by issuer-country transactions, we will assume an extreme set of facts: these sales to and trades among $A$ residents in shares of these issuers are not accompanied by any public sales to or trades among residents of $B$ (domestic transactions) or public transactions effected in $A$ (standard transactions).

\section{The Stakes of Countries A and B: A Comparison Between Issuer-Country and Standard Transactions}

It is critical at the outset to observe that the distribution of the benefits and costs of the disclosure practices of $X$ and $Y$ discussed in Part II - risk reduction and allocation of resources - is identi- 
cal whether the issuer's shares involve issuer-country or standard transactions. Differences in the stakes of countries $A$ and $B$ between issuer-country issuers and standard issuers must result from the factors just considered in the discussion of transplant transaction issuers, ones relating to the general volume of securities transactions effected within their borders. To get a picture of the total stakes of each country in the disclosure practices of the two kinds of issuers, we simply superimpose their respective volume-related interests, analyzed for transplant transactions, on their respective risk reduction, resource allocation, and cost interests, analyzed for standard transactions.

The volume issue with transplant transactions, as we have seen, comes from the fact that transplant and purely domestic transactions are potential substitutes for each other. Similarly, the volume issue with standard transactions comes from the fact that standard and issuer country transactions are substitutes for each other. We must identify the volume-related stakes for each country in the existence of a difference in the disclosure practices of issuers involved in one kind of transaction versus the other.

a. A's Regime Is the More Rigorous. First, consider the situation in which $A$ 's disclosure regime is the more rigorous. Thus, $A$ again might be the United States and $B$ again might be Germany. Some $B$ issuers would, through the market reputation effect, be attracted to make $A$ the place of share sales to and trading among $A$ investors if, as a result, they had to disclose more than if their shares were sold and traded in $B$. In other words, some $B$ issuers would be attracted to $A$ if $A$ 's more rigorous standards applied to standard transactions and $B$ 's less rigorous standards applied to issuer-country transactions.

There would also be $B$ issuers that would be attracted to make $A$ the place to buy and trade their shares for other reasons. One powerful new reason, not present with transplant transactions, is that investors from $A$ would be able to buy and trade their $B$ issuer shares more cheaply in $A$ than in $B .{ }^{126}$ Some members of this group of issuers attracted by reasons other than market reputation would be deterred from coming to $A$ if they had to meet $A$ 's more rigorous disclosure standards. These are the issuers that would find

126. This local-trading attraction exists in addition to any superiority in execution efficiency in $A$, the example of an alternative attraction given in the discussion of transplant transactions. In the real world, the local trading attraction is likely to be the more powerful one. 
their costs of compliance to exceed their benefits, even after counting the worth to them of their investors in $A$ being able to buy and trade more cheaply.

$A$, therefore, will not have a volume-related stake in standardtransaction $B$ issuers disclosing more than issuer-country $B$ issuers, unless the transactions attracted by the reputation effect exceed those deterred by the compliance-cost effect, something that is even less likely than with transplant transactions. ${ }^{127}$ Thus, with $A$ 's regime the more rigorous, absent domination by the reputation effect, $A$ will not want, and $B$ will want, location to matter in determining which country's regime is applied.

b. B's Regime Is the More Rigorous. Now consider the situation in which $B$ 's disclosure regime is the more rigorous. Thus, $A$ again might be the United Kingdom, and $B$ again might be Canada. Some $B$ issuers will find their costs of compliance with $B$ 's regime to exceed their benefits. These $B$ issuers will make $A$ the place where their share sales to and trades among $A$ residents occur to avoid $B$ 's heightened disclosure requirements. In other words, some $B$ issuers will be attracted to $A$ if $A$ 's less rigorous standards are applied to standard transactions and $B$ 's more rigorous standards to issuer-country transactions.

Some $B$ issuers also will want to make $A$ the place for their $A$ investors to buy and trade their shares for other reasons, most important, the savings it will confer on those investors. Some of these issuers will be concerned with $A$ 's lower market reputation. But, as with issuers attracted in the transplant-transaction example by $A$ 's greater execution efficiency, the issuers concerned with market reputation can presumably choose not to opt out of $B$ 's regime, while still making $A$ the place to buy and trade their shares.

$A$ therefore will have a relatively unambiguous volume-related stake in reducing the level of disclosure required of standardtransaction $B$ issuers below that required of issuer-country $B$ issuers. Thus, with $B$ 's regime the more rigorous, $A$ will want, and $B$ will not want, location to matter in determining which regime is applied.

\section{Reflections on the Role of Place}

The discussion concerning transplant and issuer-country transactions suggests a basic rule: The country with the less rigorous

127. See supra note 123 . 
regime wants location to matter in deciding which regime should apply and the country with the inore rigorous regime does not. The only exception is where the country with the more rigorous regime believes that the reputation effect will outweigh the cost-ofcompliance effect and even then only if the issuer is not its own national. At this point in the article, two things are worth noting about the role of location, each of which will be important in the next discussion concerning the appropriate apportionment of regulatory authority between countries $A$ and $B$, and later, when we seek to identify the best U.S. policy.

First, there is only one reason a country associated with a transnational transaction has any interest, based on where the transaction has occurred, in how much the issuer discloses. The reason for this is that differences in disclosure levels based on transaction location can affect the aggregate volume of transactions effected within the country's borders. These national stakes are essentially a zerosum game: The volume of transactions that one country gains from location-based disclosure rules is counterbalanced by the volume lost by the other country.

Second, as we have just seen, it is generally the country whose regime is less rigorous that wants location to matter. This means that if there are no international constraints on the behavior of states in the application of their disclosure regimes, and each state comes genuinely to understand and act on its own interests, in the future, location is unlikely to play a role in how much an issuer discloses. Where the issuer's country has the more rigorous regime, it will be the state that will not want place to matter. It has the power to enforce this preference by requiring its issuers to meet its higher standards wherever their shares are sold or traded. Where the issuer's country has the less rigorous regime, it will be the state that will want place to matter. As a practical matter, however, it is powerless to force those of its issuers whose shares are sold or traded abroad to meet the higher standards of the other country if the other country does not so require. Thus, when it is the other country that wants location to matter, the issuer's country has the power to prevent location from mattering; when the issuer's country is the one wanting location to matter, it is powerless to make that happen. 


\section{Which Country's Residents Feel THE EFFects of $B$ IsSUER Disclosure}

\begin{tabular}{|c|c|c|c|c|c|}
\hline & Standard & Transact & $\begin{array}{l}\text { on Type } \\
\text { Issuer } \\
\text { Country }\end{array}$ & Domestic \\
\hline \multirow{4}{*}{$\begin{array}{l}\text { Type of } \\
\text { Effect }\end{array}$} & $\begin{array}{c}\text { Cost of } \\
\text { Disclosure }\end{array}$ & $\mathrm{B}^{*}$ & B & $\mathrm{B}^{*}$ & B \\
\hline & $\begin{array}{l}\text { Resource } \\
\text { Allocation } \\
\text { Efficiency }\end{array}$ & $\mathrm{B}^{*}$ & B & $\mathrm{B}^{*}$ & B \\
\hline & $\begin{array}{c}\text { Undiversified } \\
\text { Investor } \\
\text { Risk }\end{array}$ & A & B & A & B \\
\hline & $\begin{array}{l}\text { Trading } \\
\text { Volume }\end{array}$ & $\begin{array}{l}\text { O-sum } \\
\text { between } \\
\mathrm{A} \text { and } \mathrm{B}\end{array}$ & $\begin{array}{l}\text { O-sum } \\
\text { between } \\
\mathrm{A} \text { and } \mathrm{B}\end{array}$ & $\begin{array}{l}\text { O-sum } \\
\text { between } \\
\mathrm{A} \text { and B }\end{array}$ & $\begin{array}{l}\text { O-sum } \\
\text { between } \\
\mathrm{A} \text { and } \mathrm{B}\end{array}$ \\
\hline
\end{tabular}

* Any change in the level of ongoing disclosure from what was expected at the time of initial sale by the issuer would instead be felt by $A$ residents.

\section{The Optimal Apportionment of Regulatory AUTHORITY}

Each country associated with a transnational securities transaction has particular interests in the issuer's disclosure practices that are related to resource allocation, risk reduction, and tradingvolume effects. Having examined these interests, we are now in a position to demonstrate the apportionment of regulatory authority among these countries that would maximize global economic welfare.

At the outset, assume a few fundamental features of issuer disclosure that are true today and are likely to continue to characterize the world in the short- and medium-term future. First, regulation of issuer disclosure will continue to be made at the national, rather than global, level and that most of the world's economic activity will continue to be undertaken by issuers having a distinct national identity. ${ }^{128}$ As the real economies of nations within certain regions such as the European Community become increasingly integrated, issuers may take on more of a regional identity and regional regulatory regimes may develop. But a world of regional regimes poses the same problems as a world of national ones, and any movement in that direction can be easily accommodated within the analysis of

128. See supra note 9. 
this article simply by substituting, where appropriate, regional issuer identities and regimes for national ones. ${ }^{129}$

Second, the level of disclosure that will maximize global economic welfare is likely to differ among issuers. These differences are related both to the nationality of an issuer itself and the nationality or nationalities of its shareholders. The differences related to the issuer's nationality arise from differences among countries in their institutional structures of corporate governance. In particular, the effectiveness of disclosure in aligning managerial interests with those of shareholders depends on both the structure of share ownership and applicable corporate law. For example, more disclosure might be called for in Britain and the United States, where hostile tender offers are an important factor, than in Germany, where they have not been. The influence of share price on the quality of project choice will also vary from one country to another, depending on how managers make capital-spending decisions. The differences related to shareholder nationality arise because of differences among countries in terms of the risk aversion of their typical investors and the extent to which they diversify their portfolios. These investor-related differences among countries, while in their combined effect are probably not as important as corporate governance structure differences, could also influence the optimal amount of disclosure for an issuer.

Finally, even if issuers around the world did not differ in their optimal level of disclosure, what that optimal level is would still be unclear. Some commentators find even the most rudimentary mandatory disclosure to be on balance harmful, and probably would hold this view whatever the nationality of an issuer or its investors. ${ }^{130}$ Others consider mandatory disclosure a necessary corrective to a clear case of market failure. ${ }^{131}$ Even those who find mandatory disclosure helpful disagree as to how helpful and how

129. Trends toward transnational economic integration will not extend to the global level with sufficient intensity to require a change in the analysis for at least the medium-term future. Transnational economic integration will require much greater transnational flow of goods, entrepreneurial talent, and noncapital factors of production than is the case today. For reasons discussed briefly in Part V, until a high level of global integration is obtained, an agreement on a global disclosure regime is also unlikely.

130. See George J. Benston, Corporate Financial Disclosure in the UK and the USA 189 (1976); Benston, supra note 80; Jonathan R. Macey, Administrative Agency Obsolescence and Interest Group Formation: $A$ Case Study of the SEC at Sixty, 15 CARDOzo L. REV. 909, 922 (1994).

131. See Lucian Arye Bebchuk, Federalism and the Corporation: The Desirable Limits on State Competition in Corporate Law, 105 HARv. L. REv. 1435, 1490-91 (1992); John C. Coffee, Jr., Market Failure and the Economic Case for a Mandatory Disclosure System, 70 VA. L. REV. 717 (1984). 
costly it is, and hence what the optimal level is. ${ }^{132}$ We simply do not know the answers to these questions for certain.

These fundamental features - the continuation of nationally based disclosure regulation and issuers with distinct national identities, the likely differences among issuers in optimal levels of disclosure, and the difficulty in knowing exactly what that optimal level is - suggest two prime criteria for assigning regulatory authority. The first is the criterion of expertise. Everything else being equal, for each of the world's issuers, the country whose officials are likely to be best informed on the relationship between the issuer's level of disclosure and the interests affected thereby should be apportioned regulatory authority. The second criterion is proper political incentive and feedback, which I shall refer to in shorthand simply as feedback. Everything else being equal, for each of the world's issuers, the country whose residents will be most positively affected if the level of disclosure required of the issuer is close to what is globally optimal and will be most negatively affected if it deviates substantially from that goal should exercise regulatory authority. When this is the case, the officials making the decision have the greatest incentive to get the required level right. If, despite this incentive, they fail because they do not fully understand the phenomena involved, they receive the most accurate negative feedback.

\section{A. The Recommended Approach}

My recommendation is easy to state: When a transnational transaction occurs, the issuer's country should be the exclusive determinant of what, if anything, the issuer should be required to disclose. Assuming that the issuer's country imposes at least as stringent requirements on the issuer as it would have if the transaction had been entirely domestic, all other countries associated with the transaction should refrain from imposing their regimes on the issuer.

Two examples in terms of U.S. practice help show how this approach, if adopted, would differ from today's. ${ }^{133}$ The United States, unlike today, would apply the Securities Act of 1933 ("Securities

132. Compare Frank H. Easterbrook \& Daniel R. Fischel, Mandatory Disclosure and the Protection of Investors, 70 VA. L. REv. 669 (1984) (assessing mandatory disclosure as a method to ameliorate the underproduction of issuer disclosure because of its positive externalities) with Coffee, supra note 131 (identifying additional reasons for mandatory disclosure that are discounted by Easterbrook and Fischel).

133. See infra Part V for a more general discussion of current U.S. practices. 
Act") 134 and the Securities Exchange Act of 1934 ("Exchange Act") ${ }^{135}$ mandatory disclosure requirements, even to a U.S. corporation that decides to go public abroad through an offering in the Euroequity market and even when the issuer imposes restrictions on the offering designed to deter its flowback into the United States. The United States, unlike today, would not apply these mandatory disclosure requirements to an offering in the United States to U.S. residents by a French issuer as long as the issuer provides, pursuant to the French regime, the same disclosure as it would have had it made a purely domestic public offering in France.

Applying the proposed approach to purely domestic transactions and to each of the three general categories of transnational transactions considered in Part III - transplant transactions, standard transactions, and issuer-country transactions - demonstrates that the approach represents the optimal assignment of regulatory authority. In each case we will continue the frequently artificial assumption that the issuer's shares are not offered or traded in any of the other categories of transactions. In the examples the issuer will continue to be from country $B$ and, where the transaction is transnational, the residence of the buyer or the place of the transaction - and sometimes both - will continue to be country $A$. If, for each of the categories, the recommended approach is the optimal assignment under this artificial assumption, it also will be the optimal allocation in the real world, in which many issuers' shares are offered and traded in some combination of purely domestic transactions and one or more types of transnational transactions.

This discussion models issuer disclosure as a linear phenomenon: if one country's regime requires a higher level than the other, the stricter country requires an issuer to disclose everything that the more lenient country requires and more. Concurrent regulation is thus equivalent to giving exclusive regulatory authority to the country with the stricter regime, and so, within the model, is a meaningless concept. In the real world, of course, the country that most observers would consider more lenient may still require disclosure of certain information of which the stricter country does not require disclosure. Concurrent regulation is therefore not meaningless, and is in fact a common occurrence. But, as I briefly will argue in the last section of this Part, if the stricter regime is generally superior to the lenient regime, the information lost by not applying the more

134. 15 U.S.C.A. \$\$77a-77aa (West 1981 \& Supp. 1997); see infra Part V for a more general discussion of current U.S. practices.

135. 15 U.S.C.A $\$ \S 78 \mathrm{a}-78 \mathrm{~mm}$ (West 1981 \& Supp. 1997). 
lenient regime as well is not likely to be important enough to justify the many problems that accompany forcing the issuer to comply with the goals of two regulators instead of one.

\section{Which Country's Regime Would Regulate $B$ Issuers}

\begin{tabular}{|c|c|c|c|c|}
\hline & \multicolumn{3}{|c|}{ Approach to Regulatory Reach } \\
\hline & & $\begin{array}{c}\text { Investor } \\
\text { Protection }\end{array}$ & $\begin{array}{c}\text { Market } \\
\text { Protection }\end{array}$ & $\begin{array}{c}\text { Issuer } \\
\text { Nationality }\end{array}$ \\
\hline & $\begin{array}{l}\text { Standard } \\
\text { Buyer from A } \\
\text { Occurs in A }\end{array}$ & A & A & B \\
\hline $\begin{array}{l}\text { Type of } \\
\text { Transaction }\end{array}$ & $\begin{array}{l}\text { Transplant } \\
\text { Buyer from B } \\
\text { Occurs in A }\end{array}$ & B & A & B \\
\hline & $\begin{array}{l}\text { Issuer Country } \\
\text { Buyer from A } \\
\text { Occurs in B }\end{array}$ & A & B & B \\
\hline & $\begin{array}{l}\text { Domestic } \\
\text { Buyer from B } \\
\text { Occurs in B }\end{array}$ & B & B & B \\
\hline
\end{tabular}

\section{B. Purely Domestic and Transplant Transactions}

The superiority of allocating regulatory responsibility exclusively to the issuer's home country is most easily demonstrated in the cases of issuers whose shares are offered and traded either entirely in purely domestic transactions or entirely in transplant transactions.

\section{Risk-Reduction and Resource-Allocation Effects}

In purely domestic transactions and transplant transactions, the investors and the issuers are from the same country - in our example, $B$. The risk reduction and resource allocation effects of such issuers' disclosure behavior thus are felt exclusively by $B$ 's residents. $B$ 's officials are obviously more likely than the officials of any other country to know the benefits and costs of disclosure that affect only its residents. They are also the officials with the political incentives to choose the disclosure level that maximizes global welfare, because, where there are no effects abroad, maximizing the welfare of $B$ 's residents maximizes global welfare. $B$ 's officials also will feel the negative feedback if, despite these incentives, they fail at first to find the welfare-maximizing level. If we look only at risk reduction and resource allocation effects of disclosure regulation, 
the expertise-feedback criteria unambiguously argue for assigning to $B$ 's government exclusive regulatory responsibility for the disclosure behavior of $B$ 's issuers.

This conclusion is hardly surprising when it comes to $B$ 's purely domestic issuers, whose shares are offered and traded exclusively at home. It is equally compelling, however, for its transplant issuers, whose shares are offered and traded exclusively in $A$.

\section{Adding in Trading-Volume Effects - First Analysis}

What will happen when we add the trading-volume effects of disclosure regulation into the analysis? Will we still want to treat transplant issuers the same way as purely domestic issuers? Assume preliminarily that the choice of which country $-A$ or $B-$ has regulatory authority over transplant issuers from $B$ has no effect on the levels of disclosure required by their respective regimes on purely domestic issuers. As discussed in Part III, the volumerelated stakes of countries $A$ and $B$ in the choice of which country governs $B$ 's transplant issuers are a zero-sum game: any gain in the volume of transactions for one country will be exactly counterbalanced by the loss in volume by the other country. There will be no net effect on global welfare. Adding trading-volume effects into the calculations thus does not affect the conclusion that $B$ should regulate both its purely domestic and transplant issuers.

\section{Adding in Trading-Volume Effects - Accounting for Intercountry Competition's Impact on Regulatory Content ${ }^{136}$}

This preliminary assumption may, however, be incorrect. Apportioning regulatory authority over $B$ 's transplant issuers to the country where the transactions occur - in our example, $A-$ generates regulatory competition. With apportionment to $A, B$ issuers will be choosing the disclosure regime by which they will be governed when they choose where their shares are going to be offered and traded. Each country wishes to maximize the volume of $B$ issuer transactions effected in its own market, because that would increase rents earned by its residents. Each would thus endeavor, everything else being equal, to set its level of required disclosure to

136. A more extended version of this discussion appears in Merritt B. Fox, The Political Economy of Statutory Reach: U.S. Disclosure Rules in a Globalizing Market for Securities 45-52, app. II (Apr. 5, 1997) (unpublished paper presented at the Conference on the Regulation of Interactional Economic Activity, Georgetown Univ. Law Ctr., on file with author). 
attract as many $B$ issuers as possible. Apportioning authority to the issuers' home country, $B$, does not generate such regulatory competition.

We initially concluded that regulatory authority over transplant issuers from $B$ should be apportioned to $B$, a choice which we have seen forecloses any regulatory competition. This initial conclusion was based on the fact that $B$ 's officials have greater expertise and are politically responsible to the people affected by the issuers' disclosure practices. This conclusion should only be changed if the competition that would arise by apportionment instead to $A$ would, despite the advantages of home-country regulation, move $A$ 's and $B$ 's required levels of disclosure closer to what is optimal in global welfare terms for the respective sets of issuers that each, in the end, regulates.

a. Preliminary Considerations. Note two considerations at the outset. First, regulatory competition is desirable only if, in the absence of regulatory disclosure, $A$ and $B$ would each require too much disclosure rather than too little. Remember that for competition to arise, $A$ must exert regulatory authority over transplant issuers from $B$. Part III showed that with authority apportioned in this way, if $A$ has the lower disclosure requirements, more $B$ issuers are likely to abandon their home country's market and promote the sale and trading of their shares in $A$ than would do so if $A$ had the higher ones. ${ }^{137}$ In other words, the regulatory-evasion effect of lower standards dominates the reputation effect of higher standards. Regulatory competition thus creates pressure to lower each country's required level of disclosure. $B$, in order to retain its own issuers, will want a lower level than it would otherwise. The same will be true for $A$ in order to attract these $B$ issuers.

Second, including the effects of regulatory competition in the analysis should not change the conclusion that purely domestic and transplant-transaction issuers should be treated alike. If one believes that such regulatory competition on balance would improve global welfare through its pressures on each country to lower its required level of disclosure, there is no reason to require an issuer to go to the inconvenience of having its shares offered and traded only abroad in order to be governed by a different regime. The location of the transaction still should not matter. For a $B$ issuer whose shares are sold and traded entirely domestically but whose

137. See supra section III.B.3. 
entrepreneurs or managers prefer that it be governed by $A$ 's regime rather than $B$ 's regime, that option should be available as long as investors are fully aware of the choice that is made. The fact that no country's domestic regime currently permits its purely domestic issuers this option, however, suggests that the claim that competition in securities regulation would be beneficial is highly controversial. ${ }^{138}$

b. The Starting Presumption: For Regulating Each State's Entirely Domestic Activities, Its Rules Are Superior to Those of Any Other State. Where, as here, the issue under study is how to regulate a given kind of behavior with transborder effects, it is conventional to presume, as a reasonable first approximation of reality, that the countries involved act in their own best interests when regulating entirely domestic versions of the same behaviors. ${ }^{139}$ This conclusion seems a reasonable starting presumption in the construction of a positive theory of such behavior and its regulation. Under this assumption, it would be undesirable to apportion to $A$ regulatory authority over transplant issuers from $B$. The resulting regulatory competition would cause the disclosure required by each country's regime to be lowered from a presumptively optimal level to a suboptimal one.

What would be the implications, though, of incorporating a more complicated theory of governmental behavior - public choice theory - into the analysis? ${ }^{140}$ Public choice theory suggests that concentrated interest group action will cause a country to regu-

138. The absence of this option in the securities law context is in stark contrast with the corporate law context. A corporation is free to choose its jurisdiction of incorporation. It is free to do business not only there, but in all other jurisdictions as well. Under choice-of-law's internal affairs doctrine, each of these other jurisdictions will respect the law of the corporation's jurisdiction of incorporation as the corporation's governing law for matters pertinent to a corporation's "internal affairs." See Restatement (SECOND) OF Conflict of Laws $\$ \S$ 301-302 (1971); see also P. John Kozyris, Corporate Wars and Choice of Law, 1985 DUKE L.J. 1, 15-18 (discussing modern trend of how internal affairs doctrine dominates, despite ensuing choice of law "revolution"). These factors, in combination, allow a firm, wherever it operates, to be governed by the corporate law of its choice.

Professor Roberta Romano, who favors such competition, has recently suggested giving even purely domestic issuers such an option. See Roberta Romano, Empowering Investors: A Market Approach to Securities Regulation (Apr. 28, 1997) (unpublished paper, presented at the Symposium on Comparative Corporate Governance, Max-Planck-Institut, Hamburg, Germany, on file with author).

139. See sources cited supra note 123.

140. For examples of public choice theory see James M. Buchanan \& Gordon TuLlock, The Calculus of Consent: Logical Foundations of Constitutional DemocRACY (1965); William A. NisKanen, BUREAUCRACY AND RePRESENTATIVE GOVERNMENT (1971); Richard A. Posner, Theories of Economic Regulation, 5 Bell J. ECON. \& MGMT. SCI. 335 (1974); Stigler, The Theory of Economic Regulation, supra note 80. 
late more than is in its national interest. Some commentators have used public choice theory applied within a purely domestic context to suggest that mandated disclosure represents overregulation at the behest of the securities industry, ${ }^{141}$ so that the required level of disclosure is suboptimally high. If so, regulatory competition might be a useful counteracting force. This may suggest that regulatory authority over transplant issuers from $B$ should, contrary to my initial conclusions, be apportioned to $A$, the country where the transactions take place.

The advocate of such an approach, however, must establish two things to overcome the conventional and reasonable starting presumption that states act in their own best interests. First, she needs to show that within a purely domestic context, concentrated interest group action results in an excessive level of mandated disclosure. Second, she needs to show that regulatory competition at the international level would be a helpful antidote to the problem. Neither will be easy to show.

\section{c. The Public Choice Critique in the Purely Domestic Context.} Several factors cast doubt on the claim that within a purely domestic context concentrated interest group actions result in an excessive level of mandated disclosure. To start, the effectiveness of public choice theory in explaining regulation generally is the subject of much debate; there is hardly consensus that most political action consists of self-interested rent seeking. ${ }^{142}$ Moreover, even if one believes that public choice theory has considerable explanatory value generally, the story may err when applied to securities disclosure. Those who use public choice theory to argue that the domestically mandated level of disclosure is excessively high may not correctly identify all of the interests of the securities industry. They may be correct that some members desire a high level of mandatory disclosure in order to reduce their costs of collecting information. Other securities-industry members, however, might prefer a low level, so that, for example, more firms would be willing to be public companies, thereby resulting in more fee-generating initial public offerings and secondary trades. They also omit consideration of

141. See Susan M. Phillips \& J. Richard Zecher, The SEC and the Public InterEST 22-23 (1981); Macey, supra note 130.

142. For reactions to public choice theory, see Dorothy A. Brown, The Invisibility Factor: The Limits of Public Choice Theory and Public Institutions, 74 WASH. U. L.Q. 179 (1996); Richard H. Pildes \& Elizabeth S. Anderson, Slinging Arrows at Democracy: Social Choice Theory, Value Pluralism, and Democratic Politics, 90 Colum. L. Rev. 2121 (1990); Cass R. Sunstein, Interest Groups in American Public Law, 38 Stan. L. Rev. 29 (1985). 
concentrated interest groups outside of the securities industry, such as the managements of established public corporations, whose interests are likely to favor low levels of required disclosure. Finally, they do not account for the possibility that the interests favoring more disclosure attributed to persons in the securities industry may serendipitously coincide with correction of important market failures in issuer disclosure due to the public goods nature of information and agency problems between the managements of established issuers and their stockholders. ${ }^{143}$

\section{d. Even If the Public Choice Critique Is Valid in the Purely} Domestic Context, Regulatory Competition Is Not Necessarily a Helpful Antidote. Assume now that the public choice story is correct and that within a purely domestic context the forces it identifies result in an excessively high required level of disclosure. This does not necessarily imply that promoting regulatory competition - assigning regulatory responsibility for $B$ 's transplant issuers to $A$ - is a helpful antidote to the problem. Issuer entrepreneurs and managers are the ones who will determine where their shares will be offered and traded. Full-fledged regulatory competition thus is likely to result in some small country, with little in the way of domestic issuers, offering a disclosure regime that requires no more disclosure than these entrepreneurs and managers find to be in their individual best interests. In other words, some country is likely to become in its disclosure laws the equivalent of Luxembourg in its banking laws. ${ }^{144}$ In essence, as a result of regulatory competition, issuer entrepreneurs and managers are likely to have the option of disclosing no more than if there were no regulation at all. ${ }^{145}$

Whether it is desirable to provide these individuals with this option depends on a comparison of two ways of coming to a decision on the proper level of issuer disclosure. Our goal is that the level chosen is the one where, at the margin, social costs of issuer disclosure just equal social benefits. One way is to rely on the decisions of issuer entrepreneurs and managers, which are based on their cal-

143. See Coffee, supra note 131; Easterbrook \& Fischel, supra note 132, at 684-85.

144. In fact, Luxembourg itself is already reputed to provide only a "nods and winks" review of offers and sales of new issues of securities listed on the Luxembourg Stock Exchange. See Manning Gilbert Warren III, Regulatory Harmony in the European Communities: The Common Market Prospectus, 16 BROOK. J. INTL. L. 19, 41 (1990).

145. Even if a securities law equivalent to Luxembourg does not develop, regulatory competition is likely to create larger pressures for all countries with major stock exchanges to lower their regulations significantly. See Fox, supra note 136. 
culations of the benefits and costs privately experienced by them. The other is to rely on the decisions of the government of the country whose residents exclusively experience the actual benefits and costs of their issuers' disclosures.

As Part II demonstrates, the entrepreneurs' and managers' calculations of private benefit and cost are unlikely to correspond closely to the social benefits and costs. Private benefits are prone to be less than social benefits and private costs are prone to be larger than social costs. ${ }^{146}$ The calculations of entrepreneurs and managers thus will be biased: they will want to disclose less than is socially optimal.

Public choice asserts that the government has biases running in the opposite direction. One would not want to promote regulatory competition by apportioning authority to $A$, however, unless one believes that the level chosen by the government is even more biased than the level chosen by legally unconstrained private entrepreneurs and managers. Few legal commentators, including those with a law and economics orientation, appear implicitly to hold that belief; few find the domestic regime of even the most rigorous country, the United States, sufficiently flawed such that a total abandonment of regulation - and hence reliance on issuers' calculations of private cost and benefit - would be preferable to maintenance of the current system. ${ }^{147}$

Some of these commentators, while favoring some disclosure regulation to none, still might prefer the less rigorous regimes of the other major capitalist countries to that of the United States. Apportioning the regulation of transplant issuer disclosure to the country where the transaction takes place, however, might well, over time, result in a race-to-the-bottom among the countries with major stock exchanges rather than toward a state in which issuers

146. See supra section II.B.

147. See supra note 143. For example, Easterbrook and Fischel conclude, after explicitly considering public choice theory, that the U.S. mandatory disclosure regime ought to be retained. See Easterbrook \& Fischel, supra note 132, at 714-15. Addressing a somewhat analogous problem within our domestic federal system of corporate and securities lawmaking, Lucian Bebchuk has argued that placing the regulation of corporate disclosure under the authority of state corporate law rather than federal securities law would, because of regulatory competition, result in a suboptimally low level of disclosure. See Bebchuk, supra note 131 , at 1490-91. Jonathan Macey, on the other hand, finds that "[a]s markets have become more efficient, society's need to devote resources to support a statutory regime of mandatory disclosure designed and enforced by the SEC has disappeared. Any information that was supplied by the force of law now is supplied by the marketplace." Macey, supra note 130, at 928. The issue of the efficiency with which markets impound the information that issuers choose to release, however, differs from the question of whether issuers will choose to release as much information as is socially optimal. See Fox, supra note 69, at 1015-25. 
disclose at the level currently required by the other major capitalist countries.

e. Public Choice Arguments for Not Promoting Regulatory Competition. Adding a public choice component to the analysis of what country should exercise regulatory authority over transplant transactions may actually add to the overall strength of my conclusion that regulatory authority should be apportioned to the issuer's home country. With regulatory competition, persons who receive rents dependent on the volume of transactions effected in a given country would enjoy gains from a relaxation of their country's disclosure standards. Public choice theory would suggest that the relaxation may occur even if these gains are less than the welfare losses to the country's residents from its issuers disclosing at a lower-than-optimal level in resource allocation and risk reduction terms. The gainers are more concentrated and more capable of political action than the losers, who are many but diffuse. No inconsistency thus necessarily exists between a belief in public choice theory and the conclusion that, in the context of a globalizing securities market, regulatory competition will result in each country having a too-low level of mandated disclosure.

f. Conclusion. Assigning regulatory authority over the disclosure practices of transplant issuers to their home country has clear advantages. Compared to the country where the sales or trades occur, the home country's governmental authorities have greater expertise concerning the resource allocation and risk reduction effects of such disclosure. They have greater political incentives to choose the right level and they receive more direct negative feedback if they get it wrong.

The argument that regulatory competition is sufficiently desirable that the country where the trades occur nevertheless should exercise regulatory authority is not persuasive. This argument is based on the claim that domestic disclosure regimes tend to require excessive disclosure and that regulatory competition will counteract this tendency. Such a claim runs contrary to the conventional and reasonable starting presumption utilized in studies concerning the regulation of behavior with transnational effects that countries' domestic regulations represent their own best interests. Moreover, a number of factors cast doubt on the proposition that in the particular area of disclosure, countries tend to overregulate. 
The conclusion that the issuer's home country is the better regulator would not change even if, for the sake of argument, we were to accept the claim that domestic disclosure regimes require too much disclosure. To be successful, the argument for regulatory competition requires a political theory akin to second best theory in welfare economics. ${ }^{148}$ As just noted, regulatory competition creates its own imperfection resulting from the increasing political pressure from members of the securities industry concerned with the volume of transactions effected in their home market. The political theory would need to show that this imperfection is optimal given the assumed imperfection that domestic disclosure standards are currently too high. Unless a proponent of regulatory competition can provide such a theory, there is no reason to believe these competition-induced political pressures will represent an appropriate antidote to the assumed problem of excessive disclosure regulation.

\section{Standard and Issuer-Country Transactions}

Now consider standard transnational transactions and issuercountry transnational transactions. In each case the buyer is from one country - in our example, $A$ - and the issuer from another in our example, $B$. Standard transactions are effected in the buyer's home country, and issuer-country transactions are effected in the issuer's home country.

Should this difference in where the transaction is effected affect which country is apportioned regulatory authority over the issuers involved? The answer is no, unless one so distrusts domestic disclosure regulation and is so persuaded of the corrective benefits of regulatory competition that one favors giving country $A$ regulatory responsibility over the disclosure practices of both transplant $B$ issuers and $B$ issuers whose shares are sold and traded only domestically but would prefer $A$ 's regime. ${ }^{149}$ The discussion above suggests

148. The theory of second best in welfare economics concerns the circumstance where, because of institutional restrictions, one condition necessary for Pareto optimality - the situation where there are no possible reallocations that can make any person better off that would not make some other person worse off - cannot be met. The theory says that if such a constraint exists, economic welfare will not generally be maximized by still trying to satisfy all the other conditions for Pareto optimality. Rather, welfare will be maximized when some other counteracting imperfection, specified by the theory, is present. See Henderson \& QuANDT, supra note 99, at 286-88.

149. If one does so distrust domestic disclosure regulation that one wishes to give country $A$ regulatory responsibility over the disclosure practices of those $B$ issuers whose shares are sold and traded only domestically but who would prefer to be regulated by $A$ 's regime, then, a fortiori, one would also want to give that option as well to $B$ issuers whose shares are involved in any kind of transnational transaction. 
the unsoundness of such beliefs. Assuming that one does not hold such beliefs, one then also should view the argument for assigning regulatory responsibility to country $A$ in the case of standard transactions issuers as no stronger than the argument for assigning it to $A$ in the case of issuer-country transactions issuers.

The fact that standard transactions are effected in $A$ and issuercountry transactions are effected in $B$ should not matter, because the only difference between standard and issuer-country issuers that their shares are sold and traded in $A$ rather than $B$ - is irrelevant to the determination of what apportionment of regulatory authority would maximize global welfare. This reasoning follows closely from the prior discussion of transplant transactions. The only way that this difference between the two kinds of issuers could matter to $A$ and $B$, in terms of their stakes in how regulatory authority is apportioned, concerns the volume effects of disclosure regulation. If $A$ were assigned standard-transaction issuers because of the additional contact to $A$, and $B$ assigned issuer-country issuers, issuers would have an incentive to have their shares offered and traded in the market of the country with the lower level of required disclosure. If both kinds of issuers were assigned to the same country, whichever that might be, there would be no such incentive. The country with the lower required disclosure thus would benefit from assigning standard issuers to $A$ and issuer-country issuers to $B$, and the one with the higher level would benefit from assigning both kinds of issuers to the same country. This sort of benefit should be irrelevant to our choice of which country should exercise regulatory authority over each category of issuer because the effects of the choice on volume of trading in each country is a zero-sum game from a global welfare point. Assigning standard issuers to $A$ and issuer-country issuers to $B$ would also, unlike assigning both groups to the same country, promote regulatory competition. For the reasons discussed above, this is not an affirmative reason for treating differently two groups of issuers, the effects of whose disclosure is otherwise identical. ${ }^{150}$

150. However we resolve the tension between $A$ determining that one level of disclosure is needed to give its non-fully diversified investors adequate risk reduction and $B$ determining that a different level is necessary in terms of resource-allocation efficiency and cost, including the place where the transaction occurs as a factor provides issuers with a method of evading that resolution. Consider the two extremes. At one extreme, we always resolve in favor of the determination of the issuer's country, $B$, because it has the resource allocation and cost stakes. In our example, if $A$ 's regime is less rigorous, taking location into account still permits evasion of $B$ 's calculations of disclosure's contribution to an efficient allocation of resources versus its costs. If $B$ has the less rigorous regime, as with transplant transactions, location will be irrelevant anyway. At the other extreme, we always resolve in favor of the determination of the investors' country, $A$, because it has the risk-reduction stakes. If $B$ 's 
But, determining that the same country should exercise regulatory authority over both issuer-country issuers and standard issuers does not identify which country should exercise the regulatory authority. As we saw in Part III, with standard and issuer-country transactions, each country has non-volume-related interests in the disclosure practices of the issuers involved. This section applies the expertness and feedback criteria in seeking to determine, for $B$ issuers whose shares are involved in these types of transactions, which country, if it were the regulator, would require disclosure at a level closer to what would be optimal for global economic welfare. It concludes, consistent with my proposed approach, that $B$, the issuer's home country, would be the better choice.

\section{The Simplified Case: Risk Reduction and Project Choice Efficiency Gains With Initially Capitalizing Firms}

Start with the simplified case in which the $B$ issuers whose shares are involved in standard or issuer-country transactions are new firms seeking capital for their initial project. Assume also that only the quality of the idea, and not the quality of management, affects future return in this world. Improved project choice is thus the only improved resource allocation efficiency gain to be considered.

First, consider expertness. Country $A$ residents exclusively enjoy the reduced risk for less than fully diversified investors resulting from greater disclosure. $A$ 's authorities know their own investors - the persons buying and trading these shares - better than $B$ 's authorities know them. They thus have more expertise concerning the extent to which these investors benefit from a reduction in risk. $B$ 's authorities know better their own real-investment opportunities. They therefore have more expertise concerning the extent to which more disclosure will lead to better project choice. They also have more expertise concerning the costs of requiring their issuers to reveal more.

Next, consider incentives and feedback. If $A$ is the country regulating transnational $B$ issuers, its officials will feel - through ordinary political processes - all of the risk reduction benefits from the level of disclosure that they choose. They thus will have the political incentives to take these benefits into account. If at any point they misestimate the extent of these benefits, they will receive cor-

regime is less rigorous, taking location into account permits evasion of $A$ 's calculation of the optimal amount of risk reduction. If $A$ 's regime is the less rigorous, place is again irrelevant. 
rective negative feedback. On the other hand, these processes will not give these officials any feeling for the benefits from improved resource allocation efficiency due to the disclosure level they choose. Nor will they receive any feeling of the costs of the chosen level. They have no direct incentives to take these factors into account. To the extent that they nevertheless try to do so but incorrectly estimate their magnitudes, they will receive no direct feedback. ${ }^{151}$

If instead $B$ is the country regulating $B$ issuers, its officials feel both the costs of the level they choose and its resource-allocation efficiency benefits, but do not feel its risk-reduction benefits. Country $B$ residents - the entrepreneurs who propose real investment projects and the suppliers of labor - exclusively enjoy the benefits of greater disclosure's improvements in project choice. The pattern of incentives and feedback with $B$ is thus just the mirror image of what it is if $A$ is the regulating country. But what do these respective patterns of expertise, incentives, and feedback imply about which country would be the better regulator?

a. A Count of Categories of Superiority Points to B. The expertise factor is divided on the benefits of disclosure and clearly favors $B$ for the costs. Incentives and feedback are distorted for both countries. Therefore, absent the difficult, if not impossible, quantification of these various factors, application of the expertise and feedback criteria cannot unambiguously point to one country over the other as the more appropriate regulator. A crude counting of each country's categories of superiority, however, points toward $B$ as the better regulator. Several more refined considerations reinforce this conclusion.

b. B's Domestic Regime's Required Level of Disclosure Is Likely to Be Closer Than A's to What Is Globally Optimal for Standard and Issuer-country Transnational Issuers From B. The country that regulates the disclosure of standard and issuer-country issuers from $B$ is likely to apply to these $B$ issuers either its own domestic regime or some modified regime that uses its own domestic regime as a starting point. ${ }^{152}$ This observation suggests assigning regulatory authority over standard and issuer-country issuers to the coun-

151. Country $B$ may, of course, put diplomatic pressures on $A$ concerning these matters. Such pressures, however, are institutionally crude and unrefined substitutes for the incentives and feedback that arise within a domestic political system.

152. See, e.g., infra notes 170-71 (concerning the rules that the United States has chosen to apply to transnational issuers). 
try whose domestic regime's required level of disclosure is closer to what would be optimal for these transnational issuers. As we will see, the issuer's home country - in our example, $B$ - rather than the investor's home country - in our example, $A$ - more likely fits this profile.

$B$ 's required level of disclosure is assumed to be optimal for purely domestic $B$ issuers. ${ }^{153}$ This means that for such an issuer, the social marginal costs of disclosing at its required level just equal the social marginal benefits. $A$ 's required level of disclosure similarly is assumed to be optimal for purely domestic $A$ issuers. In deciding which country's domestic regime is closer to what would be optimal for standard and issuer-country issuers from $B$ ("transnational $B$ issuers") we thus need to look at the costs and benefits of requiring different levels of disclosure from these issuers and see whether their situation more closely resembles purely domestic $B$ issuers or purely domestic $A$ issuers.

Suppose that whichever country is assigned regulatory authority over transnational $B$ issuers, it will require of them the same level of disclosure that it requires of its own purely domestic issuers. The costs and benefits of requiring this level of disclosure from transnational $B$ issuers are identical to those of requiring it of entirely domestic $B$ issuers, except to the extent, if any, that investors in $A$ differ from those in $B$ in the amount by which disclosure reduces their disutility from the riskiness of their portfolios. Similarly, the costs and benefits of requiring $A$ 's domestic level of disclosure from transnational $B$ issuers are identical to those of requiring it of purely domestic $A$ issuers, except to the extent, if any, that issuers from $B$ differ from those in $A$ in the costs of, and improved resource-allocation efficiency benefits from, greater disclosure. The country whose purely domestic issuers' disclosure costs and benefits most closely match those of transnational $B$ issuers will be the country for which the factor or factors constituting the exception differ less between the two countries. That appears to be country $B$, as detailed below.

Issuers from different countries likely differ more in the costs of, and resource-allocation improvements from, greater disclosure than would investors from different countries differ in terms of the riskreduction benefits of greater disclosure. The costs of, and resourceallocation benefits from, greater disclosure depend on a complex of institutional factors that will have a uniquely national flavor. These

153. See supra section IV.B.3. 
include the role of banks versus public equity issues in funding new companies and the ratio of institutional to individual share purchasers. In contrast, the amount by which an individual investor's risk is reduced by a given increase in disclosure depends on the extent of her nondiversification, regardless of nationality. The benefit to her from risk reduction depends on her level of risk aversion. It is quite possible that investors in one country are, on average, more risk averse than in another. At first blush, this would suggest differences among countries in the typical risk-reduction gain from greater disclosure. Reflection, however, suggests a counterbalancing factor. If one country's investors are more risk averse than those of another, they will be more diversified and less leveraged, and so they would experience less risk reduction for an increase in disclosure.

c. B Has Greater Expertise, Incentives, and Feedback With Respect to Disclosure's Costs and Allocational Benefits - the Factors That Differ More Between the Countries. Suppose instead that it is anticipated that the regulating country, rather than simply using its domestic rules, tailors special disclosure rules to apply to issuers from $B$ involved in transnational transactions. The regulating country would make such special rules to account for differences between the interests of residents of the other country associated with these transnational transactions and the interests of the equivalent persons in purely domestic transactions. ${ }^{154}$ In an interactive world, countries will often make such accommodations because, with reciprocity, they both can benefit.

This likely pattern of differences between countries still points to $B$ as the better regulator. The argument varies only slightly from that set out just above. As we have seen, the interests of each country's residents in the disclosure behavior of $B$ issuers relate to particular factors. The interests of $B$ residents relate to costs and allocational benefits; the interests of $A$ residents relate to risk reduction. Everything else being equal, it is better to assign regulatory authority to the country whose residents' interests relate to the factors that differ more between $A$ and $B$. This country's officials are in a better position to take account of the interests of the residents of the other country. They are relatively more familiar with

154. If $B$ was the regulating country, the nonresidents with an interest in the disclosure behavior of $B$ issuers whose shares are involved in standard and issuer-country transnational transactions would be the investors in $A$ who buy or trade these shares. If $A$ was the regulating country, it would be the entrepreneurs and suppliers of other factors of production in $B$. 
such interests because they vary less from the interests of their own residents. Applying the analysis to the problem at hand, the cost and resource allocation effects of disclosure differ more between country $A$ and country $B$. Because $B$ residents have an interest in these factors, $B$ 's officials will be better at tailoring special rules. That is, they are in a better position to understand disclosure's riskreduction effects on residents of $A$, whose situation is more similar to that of some $B$ residents, than are $A$ 's officials to understand disclosure's cost and resource allocation effects on residents of $B$. This conclusion is bolstered by the fact that the factor that differs more - the cost to the issuer of disclosure and the allocational benefits - is probably inherently more difficult to understand, and hence more difficult to get right from afar, than the risk-reduction benefits from disclosure.

\section{d. Risk Reduction Through Greater Disclosure Is a Subsidiary} National Interest. Finally, one additional consideration significantly reinforces the choice of $B$ as the better regulator: the nature of risk reduction as an interest. Only when $A$ 's regime is more rigorous than $B$ 's regime does country $A$ have a risk-reduction interest in applying its regime - rather than that of $B-$ to transnational issuers from $B .{ }^{155}$ In such a situation, $A$ 's government has available an alternative policy instrument to reduce the risk associated with investing in $B$ issuers that does not conflict with $B$ 's determination of the proper level of disclosure: a program of education and institutional reform to encourage its investors who invest in $B$ issuers to diversify more. The only reason $B$ 's disclosure level determination might not be optimal is if the typical $A$ investor is, relative to his risk aversion, less diversified than the typical $B$ investor. For passive investors, at least, being anything less than fully diversified is clearly undesirable in any event. ${ }^{156}$

155. If $A$ 's regime is less rigorous than $B$ 's, an inability to apply its regime means that $A$ 's investors get more risk reduction than would otherwise be the case. That in itself cannot be a cause for complaint. The larger amount of disclosure costs the issuer more, but those costs are borne by entrepreneurs in $B$.

156. See supra note 17 and accompanying text. A speculative investor, who trades on the basis of information that suggests to her the possibility of profit, faces a trade-off when she diversifies more. On the one hand, because fewer shares will be bought or sold on its basis, a given piece of information creates less expected profit. On the other, the investor enjoys reduced risk. If global economic welfare is the goal, however, declining to encourage diversification to enhance the opportunities of $A$ investors to make speculative profits trading in $B$ shares is not a justification for applying $A$ 's regime. Such trading is a zero-sum game among the players; the only potential gains to society come from more accurate prices. Entrepreneurs and laborers in $B$, who enjoy the efficiency benefits, gain the only benefits from more accurate prices. The expertise and feedback criteria therefore suggest that making the market safer for speculation in $B$ issuer shares is better handled by $B$ 's authorities. 
The advantage of a program of education and institutional reform is that it addresses the purely domestic problem of inadequate diversification directly, rather than trying to compensate for it with a disclosure policy that negatively affects the interests of residents of another country. ${ }^{157}$ Because of this, the allocational benefits and cost interests - which $B$ has the political incentives to pursue, as well as superior expertise and feedback - deserve more recognition in the apportionment of regulatory authority than the risk-reduction interests with respect to which $A$ is the better-positioned country.

\section{Ongoing Corporations With Ongoing Disclosure}

Now enlarge the world we are considering to include issuers that have an ongoing existence. The managers of these issuers from time to time decide to implement new projects. Once a project is implemented, they make decisions on how it is run. Two kinds of disclosure affect the efficient allocation of resources in this world. First, a firm may make new public issue disclosure. Where firms finance their projects by such share sales, less accurate prices lead to an inferior choice of projects to be implemented, just as in the simplified world. Second, a firm may make ongoing disclosure after it has received its initial injections of publicly held equity. As we saw in Part II, increasing the amount of ongoing disclosure increases the effectiveness of the market for corporate control and share-price-based compensation in limiting managers from making both project choice and operating decisions that deviate from what is optimal.

In this more complex world, we need to determine which country would be the better regulator with respect to each kind of disclosure. As to new public issue disclosure, the analysis is identical to that of the simplified world. Country $B$, the issuer's country, is the better choice. Ongoing disclosure is more complicated. It is most easily understood by first thinking of an artificial world in which there is just one $B$ issuer that makes a single offering to $A$ investors and then enlarging the inquiry to account for multiple $B$ issuers, resulting in a stream of such offerings over time.

157. The substitution of $A$ 's regime for $B$ 's in regulating transnational $B$ issuers will hurt the interests of entrepreneurs and labor in $B$ to the extent that the costs and allocational benefits of disclosure differ between the countries. $A$ 's regime will reflect calculations of these factors with respect to issuers in $A$, but not with respect to the $B$ issuers that are being regulated. 
a. The Regulation of Ongoing Disclosure in the Case of a Single B Issuer Making a Single Offering to A Investors.

\section{$i$. The Rules Governing Ongoing Disclosure in Force at the} Time of the Offering. One way of looking at the question of which country would be the better regulator of an issuer's ongoing disclosure is to ask which country, if it were chosen to regulate, would at the time of the offering have the rules requiring ongoing disclosure at a level closer to what would be globally optimal.

Investors in $A$ will know at the time of the offering which country will be the regulator of the issuer's ongoing disclosure and what the country's current rules are. Since the current rules are generally the best available predictor of what the rules in the future will be, the investors will use the current rules to form expectations concerning the firm's disclosure practices in the future. As we saw in Part III, this in turn will lead to expectations concerning both the extent to which management will deviate from optimal project choice and operating decisions over the rest of the issuer's life and the issuer's future disclosure costs. The share price will reflect these combined expectations. Entrepreneurs in $B$ will thus bear the entire expected allocational and cost consequences of the regulating country's ongoing disclosure rules, whether good or bad. Less than fully diversified country $A$ residents, in future sales and purchases of shares on the secondary market, will exclusively enjoy the expected level of disclosure's reduction in risk. This distribution of stakes in disclosure means that for each country, the patterns of expertise and feedback are identical to those present with disclosure for new public issues in the simplified case, already considered, where there are only initially capitalizing firms. Consequently, the analysis of which country would, at the time of the offering, better regulate the issuer's ongoing disclosure is, as a formal matter, identical to the analysis of which country would come up with better new public issue disclosure rules. Again, the analysis points to country $B$.

When one looks at the magnitudes of the important factors identified in the formal analysis, one can see that the case here for $B$ is even stronger than the case for $B$ with respect to new issue disclosure rules. It was suggested in the discussion of the simplified world that issuers from different countries differ more from one another in the costs of, and allocational improvements from, greater disclosure than investors from different countries differ from one another in the risk reduction benefits they enjoy from greater dis- 
closure. In the case of ongoing disclosure, the divergence between countries in terms of costs and allocational benefits is likely to be even more pronounced. This is because disclosure's effects on the ongoing project choice and operational decisions of management and on the firm's costs are more likely to be determined by institutional features that are uniquely national - the way that a particular country's issuers operate as organizations, for example - than would be disclosure's effects on the way the market in each country would choose among potential initially capitalizing firms. The same is likely to be true in terms of the costs of disclosure for ongoing firms compared to the costs of ones just starting up. Since differences between the countries in terms of the risk-reduction benefits of greater disclosure are the same whether we are talking about trading in the primary or the secondary market, this more pronounced divergence in terms of costs and allocational benefits means that the factors that are more different between the countries are even more different than in the former cases.

ii. Accounting for Regulatory Change: Which Country Would Make Better Modifications? The country that is the regulator has not written its rules for ongoing disclosure in force at the time of the offering in stone; they can change. It is the level of disclosure actually prevailing at the time that the issuer's managers consider any particular decision, not the level that was expected at the time the shares were publicly offered, that determines how much management is constrained in deviating from the shareholders' best interest. The same is true of costs. A determination of which country would be the better regulator depends not only on which one would come up with the better rules at the time of offering - according to my analysis, country $B-$ but also on which country would be better at making modifications over time.

The case for $B$ as the better modifier of disclosure rules is weaker than the case for $B$ as the initial rulemaker. Compared to $A, B$ still has superior expertise with respect to the factors that differ more between the countries. The argument that risk reduction is a subsidiary national interest is just as applicable as before. Feedback concerning the resource-allocation effects of disclosure, however, carries more ambiguous implications.

All of the public shareholders of the $B$ issuer are residents of $A$ and will be among the persons bearing ongoing disclosure's costs and enjoying its disciplining effects on management. Suppose $A$ were the regulator instead of $B$. At the time of the offering, $A$ 's 
officials would be totally indifferent to what kind of ongoingtransnational $B$ issuer disclosure rules they promulgate. Any deficiencies would be fully discounted in the price $A$ 's residents pay for the shares. Thereafter, however, these officials begin to face incentives to make modifications to their rules that would move disclosure toward the level that is in the shareholders' best interests. If in doing so they erred in their assessment, they would receive corrective negative feedback.

Now suppose instead $B$ were the regulator. The issuer's entrepreneurs, who provided the incentives for $B$ 's officials to account properly for disclosure's costs and allocational benefits at the time of offering, would now regard the sale of their shares simply as history. At least as to those shares, these entrepreneurs would be indifferent as to any modifications in the ongoing disclosure rules. In fact, to the extent that they continue in their role as managers, these entrepreneurs might even lobby $B$ 's officials to lower disclosure below what is optimal in order to make it easier to benefit themselves at the expense of shareholders.

iii. Combining the Inquiries. Despite the weaker case for $B$ in the modifications inquiry than in the rules at the time of offering inquiry, a variety of considerations suggest that overall $B$ is still the better choice as the regulator of the ongoing disclosure of the $B$ issuer.

To start, the fact that at the time of the offering $B$ would prescribe the better set of rules for ongoing disclosure is important. Regulation has its own inertia, and small changes are generally more likely than large ones. Any modifications that $B$ would make subsequent to the offering would likely just fine tune a set of rules that regulatory authorities had incentives to get right initially. In contrast, if country $A$ were the regulator, its modifications might be starting on a base that is far from optimal. Also, $B$ is the better regulator of new public issue disclosure and, everything else being equal, it is better to have the same authorities regulate both newissue and ongoing disclosure. It is less costly for the issuer to answer questions in ongoing disclosure that resemble the questions asked in connection with the public offering than to have to transition to a different set of questions.

Second, the other major group with a stake in the level of the issuer's disclosure - owners of the other factors of production, particularly labor - still are $B$ residents. They would continue to provide $B$ officials with incentives and feedback in support of a 
disclosure policy that encourages efficient managerial decisionmaking.

Third, at least initially, residents of $B$ will continue to hold all of the issuer's shares representing the entrepreneurial surplus at the time of the public offering. To the extent that the holders continue to be managers, their holdings will buffer their tendency to lobby for changes in disclosure that would lower the value of their shares. To the extent that the holders of these shares are not current managers, they could provide incentives and feedback for $B$ officials that are as balanced as what $A$ shareholders would provide for its officials. In fact, the existence of a public market in $A$ into which these shares held by $B$ residents can be sold means that there are $B$ residents who will provide $B$ officials with incentives and feedback concerning the risk-reduction features of disclosure.

Even more important, $B$ 's officials will also continue to receive strong feedback from investors in $B$ concerning the effects of its choice of disclosure level for entirely domestic $B$ issuers. Because entirely domestic $B$ issuers should have institutionally similar structures, the costs and allocational benefits resulting from their greater disclosure should be the same as from greater disclosure by issuercountry and standard-transaction $B$ issuers. Feedback concerning the choice of disclosure level for entirely domestic issuers therefore should provide information about the standard and issuer-country levels, whether or not the level of disclosure chosen for the transnational issuers is the same.

Also, the importance of the incentives and feedback that officials in $A$ would receive from their investors if $A$ were the regulator should not be exaggerated. If $A$ were the regulator of ongoing disclosure, its initial rules would likely be identical to the rules it applies to its own issuers involved in entirely domestic transactions. $A$ might make modifications for the transnational $B$ issuers, but if it did, it is unlikely that they would be great enough to cover completely the gap between what is best for $A$ 's domestic issuers and what would be globally optimal for transnational $B$ issuers. Modifications this extensive are even more unlikely if, as in the real world, there are issuers from several foreign countries, not just $B$, whose shares are publicly traded among residents of $A$. It would be an administrative nightmare for $A$ to have a specially tailored set of ongoing disclosure rules for each such foreign country.

b. The Regulation of Ongoing Disclosure in the Case of a Stream of Offerings by B Issuers. In fact there is not, of course, 
going to be just a single offering in $A$ by a single $B$ issuer. Over time a stream of $B$ issuers will engage in offerings of their securities in $A$. The country that regulates the ongoing disclosure of transnational $B$ issuers, whichever it is, will presumably apply its current rules to all issuers, new and old. In the single-issue model, with $B$ as the regulating country, $B$ 's officials, when considering any modifications to the rules governing the transnational $B$ issuer that had previously offered its shares in $A$, would receive no pressure from the issuer's entrepreneurs to account for the modification's allocational benefits or costs. In fact, the issuer's entrepreneurs, if they were still managers, might lobby these officials for a reduction in disclosure to a suboptimal level so that they could profit at the expense of the shareholders. The existence of a stream of issuers and the need to treat new and old alike will have a disciplining effect that reduces this concern. Where there is a pool of entrepreneurs in $B$ contemplating offerings in $A$ in the future, they will pressure the authorities to continue to strive for a rule mandating the optimal level of ongoing disclosure. Anything else would reduce the entrepreneurial surplus they will receive at the time of their offerings. ${ }^{158}$

\section{Additional Considerations Favoring Country B as the Exclusive Regulator of the Disclosure of Its Issuers}

Beyond preventing a regulatory "race to the bottom" and concerns for expertise and proper incentives and feedback, additional considerations favor country $B$ as the exclusive regulator of the disclosure practices of all $B$ issuers.

\section{Special Costs of Different Disclosure Levels for Different Issuers From the Same Country}

If $B$ issuers whose shares are offered to and traded among investors residing in $A$ must disclose more than $B$ issuers whose shares

158. The existence of a stream of offerings would also reduce the concerns expressed above with giving $A$ regulatory authority. In the single-issue model with $A$ as the regulating country, we saw that the officials producing the regulations that would be in effect at the time of the $B$ issuer's offering have no incentive to account for either the costs or the allocational benefits of disclosure and therefore may act irresponsibly. In contrast, where there is a stream of $B$ issuer offerings over time, the $A$ officials who are responsible for the rules in force at the time of any given new issue would be subject to pressures by the $A$ shareholders of all the $B$ issuers who had previously offered their shares in $A$. These residents of $A$ enjoy the rules' allocational benefits and suffer their costs.

This observation should not, however, change the overall conclusion that $B$ is the better regulator. With the possibility of irresponsible behavior reduced on both sides of the ledger, the single-issue model's overall conclusion that $B$ would be the better choice remains valid when we take account of the fact that there will be a stream of offerings. 
are offered and traded entirely domestically, two special kinds of costs arise. To understand the first of these costs, suppose for a moment that $B$ had a financially closed economy. No issuers have shares offered or traded in transnational transactions. All issuers are subject to the same purely domestic disclosure regime. As we saw in Part II, for the average issuer, the commercial and competitive benefits from legally mandated disclosure - the benefits that arise from acquiring information disclosed by suppliers, customers, and competitors - will cancel out the costs from the issuer's suppliers, customers, and competitors acquiring the information disclosed by the issuer. Thus, the only harm to the average issuer from requiring all issuers to reveal more is the increase in its operating costs of disclosure. The increase in commercial and competitive costs will be counterbalanced by a corresponding increase in benefits.

This discussion has assumed throughout, however, that in fact there is a subgroup of all $B$ issuers whose shares are offered and traded in transnational transactions. Problems arise if members of this subgroup are subject instead to $A$ 's regime. If $A$ 's regime requires a higher level of disclosure than $B$ 's, then transnational $B$ issuers would be providing more information to, than they would be receiving from, suppliers, purchasers, and competitors that are not in the transnationally traded subgroup. The fact that not all $B$ issuers are covered by a more rigorous disclosure regime means that the imposition of the regime on those who are covered increases their costs disproportionately. The distribution of the costs of disclosure, whether operating costs or these extra commercial and competitive costs, was analyzed earlier in discussing the stakes of country $A$. Those who do bear the disclosure costs of $B$ issuers whose shares are transnationally traded - on an expected basis, residents of country $B-$ will bear these extra costs. Suppose instead that $A$ 's regime requires less disclosure than does $B$ 's. Similar problems arise, this time with $B$ 's purely domestic issuers facing higher costs. Either way, these differences in costs create inefficient distortions in the issuers' decisions as to which markets they will sell and promote trading of their securities in.

The second cost of requiring a different level of disclosure from transnational $B$ issuers exists even if all $B$ issuers join the group. As Part II discussed, country $B$ determined the appropriate level of disclosure for $B$ issuers in a way that may well have reflected, among other things, $B$ 's calculation for its economy of the balance between disclosure's beneficial effects on static efficiency and its 
harmful effects on dynamic efficiency. Imposition of a different regime overrides this determination.

\section{The Reality That Most Transnational Issuers Will Also Have Public Shareholders at Home}

We have assumed throughout Part III and Part IV that for any given $B$ issuer, all public transactions in its shares fall exclusively into one of four categories: standard, transplant, issuer country, or purely domestic. This assumption sets up the most extreme set of facts against which to test the propositions that I have made. In the real world, however, almost all issuers whose shares are involved in one of the three transnational types of transactions are publicly traded at home as well. Indeed, in most cases, the majority of their shares are held by residents of the issuer's nationality.

This reality only further strengthens the case for apportioning regulatory authority over transnational $B$ issuers to $B$. With $B$ residents holding a significant portion of the shares of most transnational $B$ issuers, officials in $B$ will continue to receive feedback from $B$ residents concerning ongoing disclosure rules. Also, as to the shares of these issuers held domestically, officials in $B$ will have superior expertise and feedback with respect to disclosure's riskreduction features.

\section{E. The Case Against Concurrent Regulation}

The argument thus far has focused on demonstrating that if just one country is to regulate the disclosure of all $B$ issuers, $B$ should be that country. But with $B$ issuers whose shares are involved in transnational transactions, why designate just one regulating country? Why not allow concurrent regulation, as often happens today?

If $B$ 's regime is more lenient than $A$ 's regime, answering this question is easy. Concurrent regulation effectively overrides the policy determination of country $B$ that less rather more disclosure is optimal. This outcome is undesirable because $B$ has a stronger case for being the regulator than does $A$.

If $B$ 's regime is stricter, the answer to the question is more complex but the conclusion is the same. As noted earlier, in the real world, $A$ 's regime, though it might generally be regarded as more lenient, may still require disclosure of certain information not required by $B$ 's regime. While there is probably a great deal of overlap, $A$ 's regime may well try to reach somewhat different types of information. Even where $A$ 's regime tries to reach the same type of 
information, it will ask questions in a somewhat different way and so the resulting answers will contain somewhat different facts.

But if $B$ has already demonstrated its preference for more rather than less information, one might ask why not permit concurrent jurisdiction and get even more information? The benefits from concurrent regulation where $A$ 's regime is more lenient are at best unclear. The fact that $B$ prefers more disclosure to less disclosure does not mean that it prefers even more disclosure than its regime requires. If $B$ had wanted even more disclosure, it would have required it. $B$ presumably concluded that the extra costs of more disclosure were not worth the additional benefits. Also, $A$ is unlikely to have a special stake in the particular additional information that concurrent application of its regime would reveal, because $A$ 's primary stake is risk reduction. No particular kind of information is necessary for risk reduction as long as it assists in predicting future income streams with greater certainty. $B$ 's regime already requires more information to be disclosed by its issuers - and hence permits more certain predictions - than $A$ 's regime requires to be disclosed by $A$ 's own domestic issuers. As for project choice and constraining managerial deviations from shareholders' best interests, the differences between what $A$ asks and what $B$ asks are likely to be the result of differences in their domestic institutional structures. For issuers from $B$, the additional information revealed by getting answers to $A$ 's questions is unlikely to yield particularly substantial allocational and managerial discretion reduction benefits in $B$.

The costs of permitting concurrent regulation are substantial. $B$ issuers whose shares are involved in both domestic and transnational transactions must incur significant administrative costs in providing similar information asked for in somewhat different ways by multiple authorities. $B$ issuers whose shares are currently only involved in domestic transactions but who perceive that investors residing in $A$ would be interested in their shares would be deterred by the additional administrative costs of concurrent regulation from developing that market. This distortion results in a loss of economic welfare to residents of both countries. Finally, permitting the possibility of concurrent regulation raises the question of when it should be permitted: What mix of domestic and different kinds of transnational transactions would imply sufficient involvement by $A$ ? Creation and application of rules concerning this question involve an increase in legal complexity that both consumes considera- 
ble legal and administrative resources and creates uncertainty among economic actors.

The argument for exclusive regulation by $B$ is strong. Concurrent regulation is clearly unjustified when $B$ 's regime is more lenient than $A$ 's. Where $A$ 's is more lenient than $B$ 's, the benefits of adding $A$ 's regime are at best uncertain, while the costs are substantial.

\section{Application to U.S. Policy}

What are the implications of the foregoing analysis for setting the appropriate reach of U.S. mandatory securities disclosure rules? There are 36,000 issuers of publicly traded securities in the world. ${ }^{159}$ As we have seen, the barriers to a truly global market for the shares of these issuers continue to decline: financial information is becoming increasingly globalized and effecting share transactions abroad is becoming less expensive and more easy. With this trend toward globalization, an ever-larger portion of issuers will face securities transactions in their shares that have a least one U.S. dimension whether it be the nationality of the buyer, the nationality of the issuer, or the place of transaction. On which of these issuers is it in the enlightened best interest of the United States to impose its disclosure regime? In this final Part, I briefly survey the existing U.S. approach to deciding whether to impose its regime on an issuer and sketch out the need for change. ${ }^{160}$

Imposition of the U.S. disclosure regime is triggered by the public offering of, or indices of public trading in, an issuer's shares. ${ }^{161}$ As we will see, the U.S. approach to statutory reach has in practice put some weight on each of the three national dimensions of such transactions - buyer, issuer, and place of transaction. The articulated goal, however, has traditionally focused on the first of these factors: the need to protect United States investors from making damaging securities choices as a result of being poorly informed.162 This "investor protection" approach suggests that the only transactions associated with an issuer that should trigger imposition of U.S. disclosure regulation are those involving U.S. investors. Given this

159. According to the International Finance Corporation's annual survey of world stock exchanges, the total number of listed domestic companies worldwide in 1994 was 36,176 . See International Fin. Corp., Emerging Stock Markets Factbook 1995, at 21 (1995).

160. I deal with these issues much more extensively in a companion piece. See Fox, supra note 136 .

161. See infra section V.A.

162. See infra section V.A.1.a. 
goal, the rationale for including the nationality of the issuer and the place of the transaction in the determination of whether to apply the U.S. regime is presumably that they act as proxies for the probable nationality of the buyers. Information about the nationality of buyers is difficult to acquire. The fact that transactions in an issuer's shares occur in the United States or that the issuer is from the United States makes it more likely that buyers are from the United States than if this were not the fact.

In 1988, the SEC, in proposing its subsequently adopted Regulation $\mathrm{S},{ }^{163}$ articulated a different, "capital market protection" goal for the U.S. approach to statutory reach. The new goal still looks to protect certain investors from being poorly informed but reformulates the class of persons protected to be all investors, wherever resident, but only if they purchase in the U.S. market. ${ }^{164}$ While this change in the articulated goal suggests that the place of transaction should weigh more heavily in the calculations of whether to apply the U.S. regime, U.S. practice has not, at least to date, changed dramatically. ${ }^{165}$

The traditional SEC goal of investor protection and its more recently articulated goal of market protection are both misguided. The goal of U.S. securities regulation should be to maximize, to the extent that it is cost effective, the benefits enjoyed by U.S. residents from disclosure's capital allocation and managerial-agency-costreduction effects. Accordingly, U.S. practice should change so that the United States imposes its regime only on issuers of U.S. nationality ${ }^{166}$ but does so regardless of where transactions in the issuer's shares occur or the nationality of the buyers. It is therefore in the enlightened self-interest of the United States to conform to the approach to statutory reach that I showed earlier will maximize global economic welfare. This is the case even if other countries do not follow suit.

There are two reasons for this recommended change in the U.S. approach. First, this approach discriminates among the world's is-

163. 17 C.F.R. $\S \S 230.901-904$ (1996).

164. See infra section V.A.1.b.

165. See Securities Act Release No. 6779, [1987-1988 Transfer Binder] Fed. Sec. L. Rep. (CCH) 84,242 at 89,123 (June 10, 1988) [hereinafter Reg. S Proposing Release]; infra section V.A.1.b.

166. Under this approach, the nationality of an issuer, it will be remembered, is determined by where the issuer has its center of gravity as a firm. Important factors include the locations of the entrepreneurs who formed the enterprise, the current headquarters, and where the bulk of its operations are conducted. Nationality is not determined by jurisdiction of incorporation or where the issuer's shareholders reside. 
suers more precisely than the other approaches in selecting which issuers' disclosure practices most affect the welfare of U.S. residents. Second, it prevents political pressures from developing that might otherwise lower the U.S. requirements to a suboptimal level.

\section{A. The Current U.S. Approach}

Two basic components of U.S. securities law link transactions in securities with regulations requiring issuers to disclose information about themselves. First, certain sections of the Securities Act of 1933 ("Securities Act") regulate the primary market for securities, ${ }^{167}$ imposing a set of disclosure obligations upon the offering and sale by the issuer of a new block of securities. Second, certain sections of the Securities Exchange Act of 1934 ("Exchange Act") regulate the secondary market for securities. Exchange Act disclosure obligations are triggered by indices - a listing of the issuer's shares on a securities exchange or the existence of more than a given number of shareholders - that suggest that already-issued shares of an issuer will be traded frequently. ${ }^{168}$

\section{Issuer Disclosure Triggered by Primary Market Transactions}

a. The SEC's Traditional Approach. Section 5 of the Securities Act prohibits the offer or sale of any security by any person unless the security is registered under the Act or the security or transaction is subject to an exemption. ${ }^{169}$ By its terms, section 5 makes no distinctions between foreign offerees or purchasers and domestic ones, or between transactions occurring abroad and transactions occurring at home. ${ }^{170}$ The SEC has always made clear that it interprets section 5 to cover public offerings in the United States by foreign issuers. ${ }^{171}$ This interpretation appears to be based on the SEC's traditional position that the registration requirements of sec-

167. See infra section V.A.1.

168. See infra section V.A.2.

169. See 1933 Securities Act $\S 5,15$ U.S.C. $\S 77$ e (1994).

170. Application of $\S 5$ requires only that an instrument of "interstate commerce," which is defined under $\S 2(7)$ to include "trade or commerce in securities or any transportation or communications relating thereto . . . between any foreign country and any State," 15 U.S.C. $\S 77 \mathrm{~b}(7)(1994)$, at some point be used in connection with the transaction, see 15 U.S.C. $\S 77 \mathrm{e}$ (1994).

171. Traditionally, foreign issuers wishing to offer publicly securities in the United States were required to register them on the same Form S-1 required of all domestic issuers not qualifying for one of the SEC's abridged forms. See Harold S. Bloomenthal, 1980 Securities Law Handbook 231 (1980). In 1982, the SEC, in an extension of the integrated disclosure system, adopted three registration forms exclusively for foreign issuers: the F-1, F-2 and F-3. See 17 C.F.R. $\$ \S 239.31-.33$ (1996). 
tion 5 are primarily intended to protect U.S. investors. ${ }^{172}$ A large portion of the purchasers of any public offering made in the United States would obviously be U.S. investors. The SEC's only special concern in the case of foreign issuers has been, given the public interest in attracting them to make public offerings in the U.S. market, how much it should relax the ordinary disclosure standards applicable to domestic issuers because of the special hardships the ordinary standards create for foreign issuers. ${ }^{173}$

According to the traditional rationale, the U.S. disclosure regime should not be applied to the public offering to persons abroad of shares newly issued by a U.S issuer even if some activities in connection with the offering occur in the United States. In fact, the position of the SEC for over 30 years has been not to take action against U.S. issuers for failure to register securities that have been distributed abroad to foreign nationals if the distribution is effected in a manner that will result in the securities coming to rest abroad. ${ }^{174}$

b. Regulation $S$. In 1988, the SEC issued a release first proposing its subsequently adopted Regulation $S$ rules concerning Securities Act registration exemptions for offers and sales abroad. ${ }^{175}$ In this release, the SEC articulated a shift in rationale concerning the appropriate reach of the entire U.S. disclosure regime:

[T] he registration of securities is intended to protect the U.S. capital markets and all investors purchasing in the U.S. market, whether U.S. or foreign nationals. Principles of comity and reasonable expectations of participants in the global markets justify reliance on laws applicable in jurisdictions outside the United States to define disclosure requirements for transactions effected offshore. . . As investors choose their markets, they would choose the disclosure requirements applicable to such markets. ${ }^{176}$

Concern with where the transaction is effected, which in the past had been simply a proxy for the likely residency of the person buying the security, thus becomes an end in itself.

This articulated change in goal has not, so far, resulted in a major change in practice. The rules actually adopted do not provide a wholesale exemption for every transaction effected abroad.

172. See Securities Act Release No. 4708, 1 Fed. Sec. L. Rep. (CCH) II 1361, at 2124 (July 9, 1964) [hereinafter Release No. 4708].

173. See Securities Act Release No. 6437, SEC Docket (CCH), at 964 (Nov. 19, 1982); Fanto, supra note 5.

174. See Release No. 4708 , supra note 172 , at 2124 .

175. See Reg. S Proposing Release, supra note 165 .

176. Id. at 89,128 (emphasis added) (footnotes deleted). 
Rather, the focus is on two concerns. The first is preventing directed-selling efforts in the United States of unregistered shares nominally offered only abroad. The second is preventing the "flowback" into the United States of unregistered shares initially sold abroad, particularly where the issuer is also not providing periodic disclosure under the U.S. regime. ${ }^{177}$ Regulation S applies to both U.S. and foreign issuers, but with somewhat different results.

i. U.S. Issuers. A U.S. issuer that scrupulously offers its shares only to persons residing abroad and lists them only abroad is, even with Regulation S, still ultimately likely to have to comply with U.S. disclosure requirements. This is true even though purchasers of the shares would have chosen to acquire their shares in a market outside the United States and hence, according to the SEC's newly articulated goal of market protection, have chosen foreign disclosure requirements as well. It would be difficult or impossible for such an issuer to construct a practical scheme to market its shares that would qualify for the Regulation S exemption from Securities Act disclosure. Even if it succeeds in doing so, its victory is likely to be pyrrhic: soon after, it would be likely to have to provide

177. Regulation S was proposed by the SEC in June 1988. See id. at 89,123 . It was reproposed in 1989. See Securities Act Release No. 6838, [1989 Transfer Binder] Fed. Sec. L. Rep. (CCH) If 84,426, at 80,209 (July 11, 1989) [hereinafter Reg. S Reproposing Release]. The Commission adopted Regulation S on April 19, 1990. See Securities Act Release No. 6863, [1989-1990 Transfer Binder] Fed. Sec. L. Rep. (CCH) II 84, 524, at 80,661 (Apr. 24, 1990) [hereinafter Reg. S Adopting Release]; 17 C.F.R. \$§ 230.901-.904 (1996).

Regulation S, which consists of rules governing offers and sales of securities made outside the United States, covers both U.S. issuers and foreign issuers. See 17 C.F.R. $\$ 230.903$ (1996). Rule 901 provides that $\S 5$ of the Securities Act does not cover "offers and sales that occur outside the United States." 17 C.F.R. § 230.901 (1996). Regulation S also contains, in rule 903 , a safe harbor from registration for offers and sales by issuers, underwriters, and dealers involved in the distribution of securities. See 17 C.F.R. $\$ 230.903$ (1996). To qualify under this safe harbor, the offer must be made only to persons outside the United States, it must be reasonably believed that the purchasers are outside the United States when they place their orders, and there must be no directed selling efforts in the United States. Under rule 903(c), qualification may also require meeting additional conditions designed to discourage flowback to the United States of securities offered and sold in this fashion. See 17 C.F.R. $\$ 230.903$ (c). The need to meet these additional considerations, and their severity, depends on factors suggesting the likelihood of such flowback and the extent of damage if it does occur. Such factors include the nationality of the issuer, the nature of the security, the location where the issuer's currently outstanding securities trade, and whether the issuer provides periodic disclosure under the 1934 Act.

For an overall description and analysis of Regulation S, see RICHARD W. JENNINGS ET al., Securities Regulation: Cases and Materials 519-21, 1594-612 (7th ed. 1992); Loss \& Seligman, supra note 3, at 792; Don Berger, Offshore Distribution of Securities: The Impact of Regulation S, 3 TransnatL. Law. 575 (1990); John Regis Coogan \& Thomas C. Kimbrough, Regulation S Safe Harbors for Offshore Offers, Sales and Resales, INSIGHTS, Aug. 1990, at 3; Samuel Wolff, Offshore Distributions Under the Securities Act of 1993: An Analysis of Regulation S, 23 Law \& Poly. INTL. Bus. 101 (1991-92). 
the same information under the Exchange Act periodic disclosure requirements. ${ }^{178}$

\section{ii. Foreign Issuers. A foreign issuer that offers its securities} only to persons residing abroad is likely to avoid the need to comply with U.S. disclosure requirements. Foreign issuers will find it easier to qualify under Regulation $S$. The apparent intention of Regulation $S$ is to exempt public offerings by foreign issuers where the sale is effected abroad, there are no efforts directed at United States residents to sell shares of the new issue, and the likelihood ex ante is that the securities will come to rest abroad - even if some, ex post, do ultimately come to rest in the United States. ${ }^{179}$ A for-

178. Consider a privately held issuer whose operations and management are predominantly in the United States and whose initial shareholders are primarily U.S. residents. It decides to go public only abroad. Even if the issuer is incorporated (or reincorporated) abroad, such an issuer would not qualify as a "foreign issuer" under rule 902(f). At the time of the offering, more than $50 \%$ of its shares would be U.S.-held and it would have an economic center of gravity in the United States. Thus, the only safe harbor for which the offering could qualify would be rule 903(c)(3), which imposes the most severe conditions to prevent flowback to the United States. See supra note 177. Under rule 903(c)(3), the offering must be constructed in such a way that the purchasers are non-U.S. residents who agree, for a year, only to resell to non-U.S. residents who themselves agree to similar restrictions. These restrictions prevent the shares for a year from being listed to trade in an ordinary fashion on even a foreign stock exchange and, because of the consequent reduction in liquidity, greatly reduces their marketability.

A previously privately held issuer able and willing to market its securities to the non-U.S. public under these difficult circumstances would still not, because of the Exchange Act's periodic disclosure requirements, escape the U.S. disclosure regime for long unless the offering resulted in a majority of its shares being held abroad. See infra section V.A.2.

Now consider a public offer abroad by an issuer with the same U.S. connections but whose shares are already publicly traded in the United States. It would be providing Exchange Act periodic disclosure at the time of the offering abroad. Because of this, it could qualify for rule 902 (c)(2)'s safe harbor. The conditions designed to discourage flowback under rule $902(\mathrm{c})(2)$ would not create the same roadblocks to the shares being traded on a foreign exchange immediately after the offering. But ultimately the already publicly traded U.S. issuer will find it no easier than the previously privately held issuer to avoid continued imposition of the Exchange Act periodic disclosure requirements, even if the foreign offering is so large that it leads to a majority of the issuer's shares being held by non-U.S. residents. There are only two exemptions from Exchange Act periodic disclosure based on an issuer's foreign aspects: rule $12 \mathrm{~g} 3-2$ (a) and rule 12g3-2(b). See infra notes 185-87 and accompanying text. Neither is likely to be available to the issuer being considered here. A rule 12g3-2(a) exemption would be unavailable because the issuer would still presumably have more than 300 U.S. resident shareholders. See 17 C.F.R. \& 240.12g3-2(a) (1997). A rule 12g3-2(b) exemption would be unavailable because of rule 12g3-2(d)(1), which denies the exemption to issuers whose shares are already Exchange Act registered. See 17 C.F.R. § 240.12g3-2(d)(1) (1997).

179. The only tricky question here is whether publicity abroad that ends up reaching both investors abroad and investors in the United States - something happening with greater frequency as the financial media become increasingly international - could constitute a directed-selling effort in the United States. Under rule 901, offers and sales "that occur outside the United States" are deemed not covered by $\$ 5$ of the Securities Act and hence do not require registration. See 17 C.F.R. \& 230.901 (1996). For offers and sales to be within the "safe harbor" provisions of rule 903 that deem them as "occur[ring] outside the United States," however, there must be "no directed selling efforts . . . made in the United States." 17 C.F.R. § 230.903(b) (1996). "Directed selling efforts" are in turn defined in rule 902(b)(1) 
eign issuer that does not have any securities publicly traded in the United States can engage in a public offering abroad and qualify for an exemption under Regulation $S$ from Securities Act disclosure without having to meet any additional conditions designed to prevent their subsequent flow to the United States. ${ }^{180}$ As we will see below, as long as the offering does not ultimately result in U.S. investors owning more than fifty percent of the issuer's shares and the issuer does not subsequently list the securities on a U.S. stock exchange or NASDAQ, the issuer will not subsequently be required to provide Exchange Act periodic disclosure either.

\section{Issuer Disclosure Triggered by Secondary Market Transactions}

Issuers, whether foreign or U.S., that have never engaged in a public offering registered under section 5 of the Securities Act can nevertheless become subject to U.S. disclosure requirements through the Exchange Act's periodic disclosure regime. ${ }^{181}$ Issuers of both types wishing their shares to be listed on a U.S. stock exchange, must, pursuant to section 12(a), register these securities with the SEC and thereby become subject to the Exchange Act's periodic disclosure regime. ${ }^{182}$

For publicly traded issuers not wishing securities to be listed on a U.S. exchange or NASDAQ, the situation is more complicated.

as "any activity undertaken for the purpose of, or that could reasonably be expected to have the effect of, conditioning the market in the United States" for the securities being offered. 17 C.F.R. § 903(b)(1) (1996) (emphasis added).

In the domestic context, the SEC has interpreted the term "conditioning" very broadly to include almost any publicity effort that reaches significant numbers of potential investors. See Securities Act Release No. 3844, 1 Fed. Sec. L. Rep. (CCH) II 3,253, at 3,148 (Oct. 8, 1957); Carl M. Loeb, Rhoades \& Co., 38 S.E.C. 843 (1959). The SEC, in its statements concerning the impact of news conferences on the availability of a Regulation S exemption, has indicated, however, that it may not be as strict in its interpretation of the term "conditioning" in the international context. See 17 C.F.R. $\$ 230.703$ (T) preliminary note 7 (1996). The SEC has recently issued for comment proposed rules that, if translated into a final rule, will clarify its definition of directed-selling efforts. See Securities Act Release No. 7392, [Current Binder] Fed. Sec. L. Rep. (CCH) If 85,909, at 89,279 (Feb. 20, 1997).

180. 17 C.F.R. $\S 903$ (c)(1) (1996).

181. Sections $12(\mathrm{~b})$ and $12(\mathrm{~g})$ of the Exchange Act set forth requirements for the registration of the securities of certain issuers. Exchange Act $\S 13(\mathrm{a})$ requires issuers registered under $\S 12$ to file, in accordance with the rules and regulations prescribed by the SEC, annual reports and current information that follow up on the original $\S 12$ registration application or statement. See Exchange Act $§ 13(a), 15$ U.S.C. $\$ \S 781,78 m$ (1994). An issuer that has engaged in an offering registered under $\S 5$ of the Securities Act must, pursuant to Exchange Act $\S 15(\mathrm{~d})$, provide on a continuing basis the same annual reports and current information. See Exchange Act $\$ 15(\mathrm{~d}), 15$ U.S.C. $§ 77$ e (1994).

182. Section 12(a) prohibits any member, broker, or dealer from effecting on a national securities exchange any transaction in "any security" not registered in accordance with the provisions of the Exchange Act. See Exchange Act $\S 12(a), 15$ U.S.C. $\S 781$ (1994). No distinction is made in the statute between a security of a foreign issuer and one of a U.S. issuer. The SEC has not interpreted the statute's reach more narrowly than its terms. 
Issuer nationality can have an important effect. First consider foreign issuers. Exchange Act section $12(\mathrm{~g})(1)$ requires any issuer having assets of more than ten million dollars and a class of equity securities held of record by 500 or more persons to register such securities under the Act. ${ }^{183}$ The section makes no distinction between domestic and foreign in terms of the nationality of the issuer or its shareholders or the location of the issuer's assets. ${ }^{184}$ The SEC, however, has exempted from these requirements any issuer that has sufficiently foreign characteristics to be considered a "foreign issuer" 185 and that: (i) has no class of equity with more than 300 holders resident in the United States, ${ }^{186}$ or (ii) furnishes the SEC with the disclosure information required by its home country's regime (this second basis not being available for issuers first listed on NASDAQ after October 1983). ${ }^{187}$ In effect, the SEC is imposing its own disclosure system on foreign issuers wishing to commence listing of securities on a national securities exchange or NASDAQ and, for all others, is accepting as adequate the disclosure system of their home countries. ${ }^{188}$

183. Section $12(\mathrm{~g})(1)$ requires every issuer who is engaged in interstate commerce or whose securities are traded by use of any means of interstate commerce and who has total assets exceeding $\$ 1$ million and a class of equity security held of record by 500 or more shareholders to register such securities with the SEC and provide information comparable to that required by a $\S 12$ (b) registration. See Exchange Act $\S 12(\mathrm{~g})(1), 15$ U.S.C. $\S 781(\mathrm{~g})(1)$ (1994). Rule $12 \mathrm{~g}-1$ exempts from this requirement issuers with total assets not exceeding $\$ 10,000,000$. See 17 C.F.R. $\$ 240.12 \mathrm{~g}-1$ (1997).

184. The text of subsection $12(\mathrm{~g})$ as a whole, which was added by amendment to $\S 12$ in 1964, see Securities Act Amendments of 1964, Pub. L. No. 88-467, §3, 78 Stat. 565, 565-68, clearly suggests that $\$ 12(\mathrm{~g})(1)$ is to apply to foreign issuers as well as domestic. See Exchange Act $\S 12(\mathrm{~g}), 15$ U.S.C. $\$ 781$ (a) (1994). There is explicit provision in $\S 12(\mathrm{~g})(3)$ for the SEC - by rule or regulation - to exempt any security of a foreign issuer. See Exchange Act, $\S 12(\mathrm{~g})(3), 15$ U.S.C. $\$ 78 \mathrm{l}(\mathrm{g})(3)(1994)$. This interpretation is confirmed by the legislative history of the amendment. See H.R. REP. No. 88-1418, at 11 (1964), reprinted in 1964 U.S.C.C.A.N. 3013, 3023-24.

185. To qualify, the issuer must be a "foreign private issuer," as defined under rule $3 \mathrm{~b}-4$. See 17 C.F.R. § 240.3b-4(c) (1997). This requires the issuer to be organized under the laws of a foreign country and, if its operations are sufficiently connected with the United States, have no more than $50 \%$ of its voting securities held by U.S. residents. See 17 C.F.R. $\$ 240.3 b-4$ (1997).

186. See Rule 12g3-2(a), 17 C.F.R. $§ 240.12 \mathrm{g3}-2$ (a) (1997).

187. The SEC in 1983 amended rule $12 \mathrm{~g} 3-2$ to eliminate the availability of the $12 \mathrm{~g} 3-2$ (b) exemption for all foreign issuers quoted on the automated quotation system of the National Association of Securities Dealers (NASDAQ), unless the issuer was already quoted on NASDAQ prior to the date of the amendment, and was and continues to be in compliance with the requirements of the exemption. The reasoning for eliminating the exemption was that "trading on NASDAQ is substantially the same as trading on an exchange and therefore the information available ... should be essentially the same." Exchange Act Release No. 20,624 [1983-1984 Transfer Binder] Fed. Sec. L. Rep. (CCH) II 83,435, at 86,293 (Oct. 6, 1983).

188. This acceptance of the disclosure system of the issuer's domicile has been strongly criticized by Professor Buxbaum. See Richard M. Buxbaum, Securities Regulation and the Foreign Issuer Exemption, 54 CORNELL L. REV. 358 (1969). More recently, some commentators have pointed out that many such securities are traded within the United States via "pink 
For the typical publicly held U.S. issuer not listed on a U.S. exchange, domestic trading or holdings in the United States are by themselves sufficient to trigger imposition of the Exchange Act periodic disclosure regime. Consider, however, a U.S. issuer with a majority of its assets and management in this country that, perhaps in an attempt to avoid U.S. disclosure rules, chooses to become a public company but decides to do so only abroad. In other words, it engages in no domestic public offerings, and it facilitates the trading of its securities only abroad. ${ }^{189}$ Section 12 (a) is not a problem for such an issuer because 12(a)'s registration requirements would only be triggered by a listing of the issuer's shares on a U.S. stock exchange. ${ }^{190}$ Section $12(\mathrm{~g})$ may well still be a problem, however. The simple fact that the issuer has gone public, regardless of where most of its shareholders reside, is enough to trigger imposition of the U.S. regime if the issuer remains incorporated in the United States. ${ }^{191}$ If the issuer reincorporates abroad, it might escape the

sheets." See Hal S. Scott \& Philip A. Wellons, International Finance: Transactions, Policy and Regulation 50 (3d ed. 1996) (discussing Cochrane et Al., supra note 12 , at 11-13). Pink sheets are stock quotations published twice daily by the National Quotation Bureau that include the names and telephone numbers of market makers. See id. In 1994, over 7600 foreign securities, and 440 American Depository Receipts (ADRs), traded through pink sheets. See id. These trades averaged $\$ 136.2$ million in daily dollar value. See id.

189. Research reveals at least one previously nonpublic U.S. company, International Signal and Control Group, that listed and offered its shares on the London Stock Exchange in order to avoid U.S. disclosure requirements. See John H. Ehrlich, Comment, Internationalization of Stock Markets: Potential Problems for United States Shareholders, 7 Nw. J. INTL. L. \& Bus. 532, 550 (1986).

190. A listing on a foreign stock exchange would not, under $\S 12(a)$, trigger a need for such an issuer to register securities: section 12(a) applies only to transactions on a "national securities exchange." See Exchange Act § 12(a), 15 U.S.C. § 781(a) (1994). No foreign exchange is currently registered as a "national securities exchange." See 2 Fed. Sec. L. Rep. $(\mathrm{CCH})$ II $21,310.10$, at 15,705 (Feb. 2, 1994).

191. This assumes that the issuer is not so insignificant that it has less than $\$ 10$ million in total assets. It also assumes that by going public, the issuer has a class of equity securities with more than 500 holders located somewhere in the world. If these assumptions are correct, as long as the issuer remains incorporated in the United States, it would appear to be required by $\S 12(\mathrm{~g})(1)$ to register its securities. Section $12(\mathrm{~g})(1)$, as we have seen, makes no distinction between foreign and domestic security holders. Because foreign issuers are covered unless exempted pursuant to a rule or regulation, see supra note 184, this issuer, being from the United States, surely would, absent such an exemption, be covered as well, even if most of its shareholders are abroad. No exemption is available for this issuer. Rule $12 \mathrm{~g} 3-2$ is the only exemption that concerns the foreign characteristics of securities potentially subject to Exchange Act registration. See supra notes 185-87 and accompanying text. Assuming that the issuer in question is incorporated in the United States, neither branch of the rule would provide an exemption, because both require the issuer to be a "foreign private issuer." See supra note 185. A corporation, to be a "foreign private issuer," must, under rule $3 \mathrm{~b}-4$, be incorporated under the laws of a foreign country. See 17 C.F.R. § 240.3b-4(b)-(c) (1997).

At least four issuers incorporated in the United States, but with fewer than 300 U.S. resident shareholders, have applied, however, pursuant to the Exchange Act's catch-all exemption, $\S 12(\mathrm{~h})$, for an order of the Commission exempting them from registration under $\S 12(\mathrm{~g})$. In each case, the Commission appears not to have issued the requested order. The 
U.S. disclosure regime. The requirements for doing so, however, are strict: public offerings of its securities must be made exclusively abroad, and, from the moment it becomes a public company whether through a public offering or by share ownership growing in some other fashion to at least 500 holders - a majority of shares must be held by persons residing abroad. ${ }^{192}$ Such an issuer would be entitled to an exemption on the same basis as a foreign issuer. ${ }^{193}$

\section{Conclusion}

In summary, U.S. practice currently works as follows. Issuers that I categorize as U.S. nationals - those with their economic center of gravity in the United States - are generally subject to the U.S. regime. Potential escape is available through a combination of going public only abroad and incorporating abroad, but only for those issuers that meet strict requirements limiting the extent of their U.S. ownership. For those that meet these strict requirements, actual escape depends on the same factors as apply to foreign issuers. Foreign issuers are subject to the U.S. disclosure regime if they offer their shares in the United States or list them on a U.S. stock exchange or NASDAQ, but otherwise can probably escape the U.S. regime.

staff of the Division of Corporate Finance stated that it would not raise any objection if the issuers did not register their securities under $\$ 12(\mathrm{~g})$. See Equitable American Property Co., SEC No Action Letter, [1990 Transfer Binder] Fed. Sec. L. Rep. (CCH) I 79,403 (Dec. 19, 1989); Paribas Properties, Inc., SEC No Action Letter (Feb. 29, 1988), available at 1988 SEC No-Act LEXIS 222; States Properties, Inc., SEC No Action Letter (Nov. 30, 1987), available at 1987 SEC No-Act LEXIS 2785; Petrogen Petroleum, Inc., SEC No Action Letter (Oct. 12, 1987), available at 1987 SEC No-Act LEXIS 2549.

As of January 1987, there were 14 U.S. companies traded on the London Unlisted Securities Market (USM). For most of these companies, however, the reported attraction of London was the lower cost of an initial public offering rather than avoidance of U.S. disclosure rules. See Philip Coggan, Low Costs Attract, Fin. Times (London), Jan. 20, 1987, at 6. Since that time, the London Stock Exchange has closed the USM to make way for its new creation, the Alternative Investment Market (AIM). See Christopher Price, Opportunities for Investors: Managers' Ability Is the Key, Fin. Times (London), Mar. 14, 1997, at 3. Most of the companies previously listed on the USM have found their way to AIM, which now has 259 listed issuers. See id. At least one company, however, moved to NASDAQ. See LBMS to Opt for American Listing, THE Times (London), Sept. 29, 1995, at 28.

192. Should the issuer in question, despite having a majority of its assets and management in the United States, choose to incorporate abroad, it would be, under Exchange Act rule 3b-4(b), a "foreign issuer." See 17 C.F.R. § 240.3b-4(b) (1997). It can be exempt from registration under rule $12 \mathrm{~g} 3-2$ if it has no more than 300 holders resident in the United States or furnishes the SEC with the disclosure information required by authorities abroad, see supra notes 186-87, but only if it qualifies under rule 3b-4(c) as a "foreign private issuer." See 17 C.F.R. \& 240.3b-4(c) (1997). That would require not only foreign incorporation but also that no more than $50 \%$ of outstanding voting securities be held by U.S. residents. This might or might not be true of a corporation originally owned by its founders, private-offering investors, and employees and that subsequently goes public abroad.

193. See supra notes $183-88$ and accompanying text. 
Where an issuer is of U.S. nationality, the issuer is thus very likely to need to comply with the U.S. regime. Where a significant number of transactions in an issuer's shares are effected in the United States, it is fairly likely that the U.S. regime will be applied as well, even if the issuer is foreign. Where a significant number of purchasers of an issuer's shares are U.S. residents, but the issuer is foreign and the shares are neither offered in the United States nor listed on a stock exchange or NASDAQ, the U.S. regime will probably not be applied.

\section{B. A Switch to the Issuer-Nationality Approach Would Enhance U.S. Welfare}

\section{Selection of Issuers}

The United States has a strong interest in the disclosure behavior of U.S. issuers. Greater disclosure, through its beneficial effects on capital allocation and on aligning managerial and shareholder interests, leads to greater returns on capital utilizing projects. ${ }^{194}$ It also leads to greater costs. ${ }^{195}$ The suppliers of capital, entrepreneurs, and the suppliers of the other factors of production - primarily labor - share the returns on such projects, after subtracting these costs. The global return on capital, whatever the issuer's disclosure practices, sets capital's share. ${ }^{196}$ Thus it is the entrepreneurs and labor associated with U.S. issuers, who are concentrated in the United States, that primarily feel the cost and benefit effects of the disclosure behavior of U.S. issuers. ${ }^{197}$ U.S. officials are best situated to decide if the disclosure of these issuers needs regulation and, if so, at what level. This is equally true whether the issuer's shares are traded only at home and held primarily by U.S. investors or traded only abroad and held primarily by foreign investors.

The United States has only a weak interest in the disclosure behavior of foreign issuers, even those whose shares are predominantly owned by U.S. investors. Because the U.S. investors will receive the global expected rate of return on capital, whatever a foreign issuer's disclosure practices, concerns about improving the expected rate of return for U.S. investors do not justify U.S. regula-

194. See supra section II.A.3.

195. See supra section II.B.

196. See supra section III.A.1.

197. See supra section III.A.2. 
tion of such issuers. ${ }^{198}$ More disclosure by these foreign issuers would benefit less than fully diversified U.S. investors through reduction in the risk of their portfolios. ${ }^{199}$ Regulation on this basis, however, is less vital, because these investors can also reduce risk simply by diversifying more. Not only are the benefits to the United States from regulation of foreign issuers less, but the costs to the United States are greater. Such regulation can reduce the availability of foreign issuer shares to U.S. investors. This is welfare decreasing for U.S. investors, even if the excluded foreign issuers would have disclosed only at a very low level. ${ }^{200}$ It also can lead to foreign-relations problems.

The place where an issuer's shares are traded does not affect these conclusions. The only U.S. interests at stake are persons whose rents depend on the volume of share transactions effected in the United States. Because the United States has the strictest regime, these interests will be hurt, not helped, by having application of the U.S. regime depend, in part or in whole, on whether transactions in an issuer's shares are effected in the United States. Such a policy's negative effect - issuer managers deciding to have their shares traded outside the United States in order to evade the strict U.S. rules - will dominate its positive effect - issuer managers deciding to have their shares traded in the United States in order to enhance their reputations. ${ }^{201}$

\section{The Prevention of Political Pressures to Lower U.S. Disclosure Requirements to a Suboptimal Level}

The market for securities, as we saw in Part I, will become increasingly global in the future. Globalization has two components: investors everywhere will be at a diminishing information disadvantage concerning issuers from other countries, and effecting share transactions abroad will become increasingly inexpensive and easy. Globalization has important implications for the U.S. mandatory disclosure regime, which is currently the strictest in the world. ${ }^{202}$

198. See supra section III.A.1.b, which also includes a discussion of why the United States has only a weak interest even if there is not a single risk-adjusted global expected rate of return on capital.

199. See supra sections II.A.2 \& III.A.

200. See supra sections II.A. 2 \& III.A.

201. See supra sections III.B.2-3 \& III.C.3.

202. The United Kingdom is a critical country for comparison with the United States. The United Kingdom is the home of the International Stock Exchange (formerly the London Stock Exchange), which, along with the New York Stock Exchange and the Tokyo Stock Exchange, is one of the world's three major stock exchanges. The United Kingdom is considered by the SEC to have disclosure requirements that are closer to those of the United States 
The current U.S. approach to statutory reach includes as relevant factors the nationality of the buyers and the place where the transactions occur. If we maintain this approach, increasing globalization is likely to cause a significant reduction in the U.S. level of required disclosure. This relaxation of the U.S. regime will result from increasing political pressure by persons seeking to maximize the number of transactions effected in the U.S., most prominently from members of the U.S. securities industry, and will occur even if, as seems likely, it diminishes U.S. welfare. A switch to a pure issuer-nationality approach would avoid these pressures and hence the welfare-diminishing reduction in required disclosure.

\section{a. Globalization-Induced Pressures to Lower U.S. Disclosure Standards.}

i. The Issuer-Nationality Approach. This statutory-reach-approach-based disparity in the impact of globalization on the strictness of the U.S. regime relates to a particular kind of issuer

than those of other countries (except Canada). See Securities Act Release No. 6568, [19841985 Transfer Binder] Fed Sec. L. Rep. (CCH) II 83,743, at 87,319 (Feb. 28, 1985). Nevertheless, a detailed comparison between the disclosure requirements of the United States and the United Kingdom for companies that issue equity securities reveals that the United States requires significantly more information. Differences between U.S. and U.K. requirements include differences in the amount of detail that must be provided describing the nature of the issuer's business and the results of the various lines of business in which the issuer participates; the need to discuss management-identified trends that may affect its future liquidity, capital needs, or operating results; and the need to provide information concerning management compensation and share ownership. See David H. Landau, Note, SEC Proposals to Facilitate Multinational Securities Offerings: Disclosure Requirements in the United States and the United Kingdom, 19 N.Y.U. J. INTL. L. \& Pol. 457, 459-68 (1987); see also BENSTON, supra note 130, at 20-21, 37; 1987 SEC INTERNATIONALIZATION REPORT, supra note 33, at III-91. European countries in general put much less emphasis on full disclosure. See Peter Widmer, The U.S. Securities Laws - Banking Law of the World? (A Reply to Messrs. Loomis and Grant), 1 J. Comp. Corp. L. \& Sec. Reg. $39-40$ (1978). Japan, the home of the Tokyo Stock Exchange, has a securities statute that closely parallels the Securities Act and the Exchange Act of the United States. However, the staff responsible for promulgating regulations and enforcement is very small compared to that of the SEC. Many provisions of the statute are treated as inoperative. The emphasis is on de facto screening of issuers by regulatory authorities rather than full disclosure. See 1987 SEC INTERNATIONALIZATION REPORT, supra note 33, at III-127; Kunio Hamada \& Keiji Matsumoto, Securities Transaction Law in General, in DoING Business IN JAPAN § 1.02[1], [4] (Zentaro Kitagawa ed., 1996).

The United States, in addition to having a set of regulations and an administrative apparatus that solicits more information from issuers than those of other countries, has a liability system that prods more information out of issuers. Under $\S 11$ of the 1933 Securities Act, the issuer is absolutely liable for materially false or misleading statements in the registration statement. See 1933 Securities Act $\S 11,15$ U.S.C. $\$ 77 \mathrm{k}$ (1994). The underwriter is liable as well, unless, under $\S 11$ (b), he sustains the burden of proof that after conducting a reasonable investigation ("due diligence") he believed the statements at issue to be true. See $1933 \mathrm{Se}$ curities Act § 11(b)(3), 15 U.S.C. $\$ 77 k(b)(3)$ (1994). The liability system in the United Kingdom, for example, is not as far reaching. See 1987 SEC InTERnAtionalization RePort, supra note 33 , at III-116. 
sensitivity. This is the sensitivity of issuers to the level of disclosure required by the U.S. regime when they make their choices as to whether or not to have their shares offered or traded in the United States. The greater this sensitivity, the larger the portion of issuers currently unwilling to have their shares offered or traded in the United States that would change their minds in response to a lowering of the U.S.-required disclosure level by any given amount. Greater issuer sensitivity leads to a greater desire by interests whose well-being depends on the volume of transactions effected in the United States to have the U.S. disclosure level lowered.

Under a pure issuer-nationality approach, an issuer's choice of whether or not to have its shares offered or traded in the United States would have no impact on whether the U.S. regime is applied to it. Issuers thus are completely insensitive to the required disclosure level of the U.S. regime, and there is no reason globalization would change this. ${ }^{203}$ Consequently, globalization would not increase the pressure on U.S. officials to lower the U.S. disclosure requirements.

ii. The Current Approach. Under the current U.S. approach to statutory reach, factors relating to the nationality of the buyers of an issuer's stock and the country where transactions in shares occur are taken into account in determining whether to apply the U.S. regime. As a result, issuers are sensitive to the level of U.S. disclosure standards. The issuer can often avoid being subject to the U.S. regime by a strategy of not offering shares in the United States and of discouraging or preventing secondary trading there. ${ }^{204}$ We have seen that issuers, left unregulated, are likely to disclose at a level lower than is socially optimal, in part because they bear all the costs of their disclosures but do not enjoy all the benefits. ${ }^{205}$ Issuers, U.S. and foreign alike, would therefore prefer to be regulated by a less

203. The desensitizing effect of a switch to the issuer-nationality approach will also enhance welfare in terms of an issuer's choices as to where to have its shares offered and traded. The choice of each issuer, rather than being guided by an effort to come under the regulatory regime it prefers, will instead depend on the economic fundamentals of the situation: the efficiency with which different markets effect trades, the country or countries of residence of their most likely investors, and the extent to which such investors find markets in their own country or countries the cheapest and most convenient places to transact.

204. Location is an explicit factor not only under the market-protection approach - in which it represents the whole concern, see supra section V.A.1.b - but under the investorprotection approach as well, see supra sections V.A.1.a and V.B. The strategy also helps issuers avoid the U.S. regime because, without offerings or secondary trading in the United States, two other indicators used by the United States in determining whether or not to apply its regime - the percentage of their shares held by U.S. residents and the absolute number of such U.S. holders - are likely to be lower as well. See supra section V.B.

205. See supra section II.B. 
strict regime than the U.S. regime, even if being subject to the U.S. regime confers some reputational benefit. ${ }^{206}$ This means that under the current approach, issuers will have an incentive not to offer their shares in the United States and to discourage or prevent secondary trading there as well.

Avoiding the U.S. market, however, also involves a sacrifice. It reduces the pool of potential investors in the issuer's shares and thus leads to a lower share price. Each publicly traded issuer in the world, in deciding whether to have its shares offered and traded in the United States, must compare this sacrifice to the burden of complying with the U.S. disclosure regime. ${ }^{207}$ Those that find the sacrifice less than the burden of compliance will avoid the U.S. market. Their absence represents foregone rents for U.S. persons whose welfare depends on the volume of transactions effected in the United States. In order to minimize the number of issuers avoiding the U.S. market, these persons can be expected to exert ongoing pressure on U.S. officials to lower U.S. disclosure requirements.

Avoiding the U.S. market traditionally has constituted a particularly big sacrifice for U.S. issuers because the United States is the residence of a large portion of their most likely potential investors. Hardly any U.S. issuers have chosen to do so. ${ }^{208}$ The converse of this proposition is that for many foreign issuers, avoiding the U.S. market has been much less of a sacrifice. In fact, most foreign issuers - all but about 700 out of total of about 28,400 - have avoided

206. See supra section II.C.2. Consistent with the rest of this discussion, this statement assumes that, absent international regulatory competition, each country's required disclosure level will be at least as high as the socially optimal one for issuers of its nationality. Even if this assumption is not correct, the United States would still attract more issuers by lowering its required level of disclosure as long as that level starts out at least as high as is socially optimal for U.S. issuers and the level of what is socially optimal for issuers of each other country is no higher than that for U.S. issuers.

207. Compliance with the Exchange Act's periodic disclosure requirements is necessary for any foreign issuer's shares to trade on a U.S. stock exchange. See supra notes 182-88 and accompanying text. Through a grandfathering provision, a number of foreign issuers that were trading over NASDAQ prior to October 6,1983, have been permitted to continue to do so by meeting a substitute, minimal disclosure requirement. See supra note 187 . Any foreign issuer wishing to commence NASDAQ trading at this point, however, must undertake full compliance. See id. Full compliance is not necessary for a foreign issuer's shares to be traded in the United States in a forum other than an organized U.S. exchange or NASDAQ. Such an issuer can commence having its shares traded among U.S. brokers on the basis of "pink sheets" simply by meeting the same substitute minimal requirements imposed on the grandfathered NASDAQ issuers. The spreads associated with this kind of trading are considerably larger, however. Investors purchasing these shares will experience a lower expected return and less liquidity. See, e.g., Iain Jenkins, 'Pink Sheets' Mix Risk with Rewards, INTL. Herald TRIB., Nov. 19-20, 1994, at 19 (asserting that the spread in the OTC market for ADRs can be as much as $10 \%$ ).

208. See supra note 189. 
the U.S. market. For them, the sacrifice is small enough to be less than the burden of complying with the U.S. regime. ${ }^{209}$ Globalization, however, will change the extent of sacrifice for both U.S. and foreign issuers.

\section{iii. The Impact of the Global Diffusion of Financial Informa-} tion. The increasing global diffusion of financial information will diminish the information disadvantage that all investors face with regard to issuers from countries other than their own. Assume for a moment that it is impossible to effect orders abroad: initial share purchases and subsequent secondary trades by U.S. residents occur only in the United States, whatever the nationality of the issuer. This assumption isolates the effect of global diffusion of information on issuer sensitivity from the effect of the further reduction in the cost and difficulty of effecting transactions abroad. With this assumption, a U.S. or foreign issuer will, under the current approach to statutory reach, have to comply with U.S. disclosure rules in order to have a significant number of U.S. resident investors. The larger the number of the world's issuers that choose to comply, the larger the total volume of transactions effected in the United States. ${ }^{210}$

Today, almost all U.S. issuers comply with the U.S. regime and have their shares traded in the United States because the sacrifice of relying on foreign investors alone is too great. Thus, U.S. issuers currently are insensitive to lowering U.S. standards, because they are all traded in the United States anyway. With the global diffusion of financial information, however, the costs to a U.S. issuer of relying solely on foreign investors will decrease. Absent an action by the United States to make its disclosure requirements more lax,

209. According to the International Finance Corporation's annual survey of world stock exchanges, the total number of listed domestic companies worldwide in 1994 was 36,176 . See INTERNATIONAL Fin. CoRP., supra note 159, at 21. Of these companies, 11,291 were in the world's developed markets outside of the United States and 7770 were U.S. companies. See $i d$. As of September 1995, there were 602 SEC-registered and reporting foreign companies listed on the New York Stock Exchange, the American Stock Exchange, and NASDAQ. See COCHRANE ET AL., supra note 12, at 10. One hundred registered and reporting foreign companies were trading over-the-counter. See id. at 10 n.8. Another 1173 unregistered foreign companies were trading over-the-counter, exempt from the SEC's reporting requirements under $\S 12 \mathrm{~g} 3-2(\mathrm{~b})$. See id. at 10 . The 242 foreign companies currently being traded on the New York Stock Exchange represent only about one-tenth of the overseas companies that meet the Exchange's listing qualifications. See id. at 2.

210. Implicit in this analysis is the assumption that if U.S. residents have made available to them the shares of a greater array of the world's issuers, they will both save more and invest a larger portion of their savings in equities. This seems plausible given the significant improvement in the trade-off between risk and return that can be attained through international diversification of equity investment. See supra Part I. 
a significant number of U.S. issuers may in the future opt to offer their shares and have their shares traded only abroad. These issuers would be induced to stay at home, however, if U.S. standards were lowered sufficiently. In the future, the volume of trading of U.S. issuer stocks thus will be sensitive to a relaxation of the U.S. regime.

In contrast, there is no reason to believe that the sensitivity of foreign issuers will significantly increase or decrease. Foreign issuers will be sensitive to a lowering of the U.S. required level of disclosure both now and in the future. Aggregating the effects of further globalization on U.S.- and foreign-issuer sensitivity, a given drop in the level of disclosure required by the U.S. regime would, under the assumption of this subsection, increase U.S. trading volume more in the future than now. Globalization will thus increase the political pressure to relax the U.S. regime.

iv. Reductions in the Cost and Difficulty of Effecting Transactions Abroad. Now consider the impact from the reduction in the cost and difficulty of effecting transactions abroad - the other component to globalization - on the sensitivity of U.S. and foreign issuers. This requires a very specific description of the U.S. approach to statutory reach and how it is implemented. If the United States adopted an exclusive investor-protection approach to statutory reach and implemented it perfectly - that is, did not rely on evidence concerning where transactions in an issuer's shares occur, whether as proxy for the residency of the shares' buyers or otherwise - a reduction in the cost and difficulty of effecting transactions abroad would not affect the pressures for a lower U.S. standard. In that situation, only the increasingly global diffusion of information would influence such pressures, and the analysis above would describe the whole story. ${ }^{211}$

In reality, however, the U.S. government is not perfectly implementing the investor-protection rationale. This article's review of current practice shows that it is more likely that the U.S. regime will

211. Any issuer seeking a significant number of U.S. buyers or holders would, in that situation, have to comply with the U.S. regime, regardless of whether or not it was selling its shares or promoting secondary trading of its shares in the United States. Such issuers therefore face no disincentive to selling and promoting their shares in the United States. Even if the cost and difficulty for U.S. residents of purchasing securities abroad substantially declined, some loss of potential U.S. investors would remain whenever an issuer's shares were not offered or traded in the United States. As in the analysis above, an issuer's decision that the benefits of access to the pool of U.S. investors outweigh the costs of compliance is therefore tantamount to a decision to offer its shares and have its shares traded in the United States. 
be imposed on an issuer if transactions in the issuer's shares occur in the United States than abroad. An issuer thus has an incentive to avoid the transacting of its shares in the United States. As it becomes cheaper and easier for U.S. investors to effect transactions abroad, this incentive increases. Issuers are no longer forgoing as many U.S. investors when their shares are only offered or traded abroad, and so the sacrifice is less. In a certain portion of cases, the fact that an issuer's shares are sold or traded only abroad will tip the balance, and the U.S. regime will not be applied. The lowering of the sacrifice associated with having shares sold or offered only abroad will induce more issuers, both U.S. and foreign, to choose that route. This will reduce the volume of transactions effected in U.S. markets relative to what it would be absent the use of location as a factor by the United States in determining whether to apply its regime.

Remember that almost all U.S. issuers today comply with the U.S. regime. Relaxing U.S. disclosure requirements therefore cannot attract additional U.S. issuers. Remember also that this will change in the future as a result of further global diffusion of financial information. Foreign demand for U.S. issuer shares will increase sufficiently that, even if it were impossible for U.S. investors to effect transactions abroad, some U.S. issuers, to avoid the current U.S. level of required disclosure, would have their shares sold and traded only abroad. Adding the second component of globalization into the analysis, this phenomenon will in fact be all the greater because it will be increasingly easy and inexpensive for U.S. investors to effect transactions abroad.

A somewhat different analysis applies to foreign issuers. A time will come when, for a U.S. investor, effecting a transaction abroad becomes almost as easy and inexpensive as effecting one at home. At that point, no reason exists for foreign issuers to tolerate current U.S. disclosure requirements - at least to the extent that the United States does not use a perfectly implemented investor-protection approach. This will be true no matter how much global diffusion of information has added to U.S. investor demand for their shares. Notwithstanding increases in U.S. investor demand for foreign issuer shares, the second component of the globalization trend will, with current requirements, in the long run decimate at least the secondary trading in the United States of shares of foreign issuers that have not previously engaged in primary offerings in the United States or listed their shares on a U.S. exchange or NASDAQ. Marginal reductions in the level of disclosure required by the U.S. 
would not help much, but a total elimination of the difference between the U.S. level and levels abroad would help a great deal. ${ }^{212}$

What then, is the overall effect of globalization's two components on the sensitivity of U.S. and foreign issuers to a reduction in the U.S.-required level of disclosure? The effect on U.S. issuers is clearly to increase their sensitivity. Many foreign issuers, on the other hand, might be almost entirely insensitive to minor reductions in the U.S. standard but very sensitive to a major reduction - one that takes the U.S. level down to the level of foreign countries. This situation will give rise to a mix of political pressures demanding, on the one hand, a major reduction in the U.S. level, and on the other, a move away from location-based tests for determining statutory reach. As discussed above, to the extent that the second element of the mix succeeds, the analysis of the effects of globalization returns to the immediately preceding section, which was devoted to the pure effects of global diffusion of information. Globalization will then be seen as increasing the sensitivity of issuers to the level of the U.S. disclosure requirements, but the reduction in cost and difficulty component to the trend would not be a contributing factor.

b. How Increased Political Pressure Under the Current Approach Can Lead to a Suboptimally Low Level of U.S. Required Disclosure. If the United States fails to switch to the issuer-nationality approach to statutory reach, there are good reasons to believe that the resulting increasing political pressures from globalization will succeed in lowering the disclosure required by the U.S. regime to a suboptimally low level.

One reason for concern is the possibility of a disclosure "race to the bottom," as the United States and other countries each compete to grab as much of the world's securities trading activity as possible. ${ }^{213}$ We have seen that it is reasonable to assume that in the prior era of relatively little transnational trading, the United States developed a.regime requiring a level of disclosure that maximizes U.S. welfare in terms of its capital allocation and agency cost of

212. The dynamic nature of the situation may make this statement a slight oversimplification. It will probably be some time before it is almost as easy and inexpensive for a U.S. investor to effect a transaction abroad as at home. Until then, some foreign issuers will be sensitive to more minor reductions in the U.S. level of required disclosure. This, combined with the fact that under the current U.S. approach to statutory reach a foreign issuer's decision to offer or list its securities in the United States and comply with to U.S. regime is essentially irreversible, might induce particularly strong political pressures for even a moderate relaxation of the U.S. regime.

213. This simple "prisoner's dilemma" game theory model is set out with more detail and rigor in Fox, supra note 136, at 45-46, app. 2. 
management reducing effects (the "substantively optimal" level of disclosure). ${ }^{214}$

Imagine the following scenario. Transnational securities transactions become more prevalent, and U.S. authorities, in a desire not to lose U.S. issuers and to attract foreign issuers, lower the U.S.required disclosure level. Assume for a moment that this would appear to be a welfare-enhancing move because, compared with maintaining the old stricter regime, the increased rents from the larger volume of transactions effected in the United States exceed the efficiency losses from requiring less than the substantively optimal level of disclosure. Other countries, however, now face a welfare loss as a result of the loss to the United States of transactions that would have occurred on their territories but for the reduction of the U.S. required disclosure level. In response, they lower their disclosure levels, seeing that the rents from the recaptured transactions exceed the welfare decline from now also having substantively suboptimal disclosure levels. Each country, including the United States, ultimately suffers a welfare loss: it has a substantively suboptimally low disclosure level and does not receive any compensating rents.

The result would be the same if another country had moved first instead. Adopting a substantively suboptimal disclosure level of required disclosure is, in game-theory terms, a dominant strategy. Each country is better off choosing this lower level of required disclosure, no matter what the other countries do. Thus, choice of this lower level by all of them is an equilibrium. Absent some difficultto-reach agreement among them, they are certain to make it.

The race-to-the-bottom story describes how, under the current approach to statutory reach, a government that acts to maximize national welfare can end up with a substantively suboptimal disclosure level. The gain in rents from increased volume, which initially exceeds the welfare loss from reduced efficiency, withers away as a result of the competitive regulatory reactions of other countries. But this race-to-the-bottom story does not need to be right to conclude that, under the current approach to statutory reach, globalization may well result in government policies representing a welfare loss to the United States. Public choice theory suggests how a government could choose a substantively suboptimal level of required disclosure when the gain in rents is insufficient, even initially, to make up for the welfare loss from reduced resource allocation effi-

214. See supra section IV.B.3. 
ciency. This is because the persons enjoying the higher rents members of the securities industry - are concentrated, whereas the losses from reduced efficiency are spread over a large portion of the public in the form of labor and suppliers of entrepreneurial talent. Politically, the actions of the concentrated gainers outweigh those of the diffuse losers.

\section{CONCLUSION}

Since their inception, mandatory disclosure rules have had at least three rationales. One is to protect investors from making poor investment decisions due to lack of knowledge. A second is to protect the reputations of the markets in which investors buy securities. A third is to promote efficiency through better capital allocation and reduced agency costs of management. These rationales coexisted peacefully for many decades because they differed little in their implications for legal choice. Their peaceful coexistence is coming to an end. Technological and political forces are moving us toward a situation where the share market for a large number of the world's issuers is becoming global. This trend raises the issue of statutory reach: Which country's disclosure regime should apply to which issuers? The different rationales give very different answers to this question.

The need to decide on the best approach to statutory reach is thus an occasion to reexamine the three rationales for mandatory disclosure. The reexamination is revealing. Investor protection, while a worthy goal for many aspects of securities regulation, is a surprisingly weak justification for mandatory disclosure rules. As for market protection, it is hard to argue that in a world of competing markets, any one market will enjoy a net gain in trading volume by having strict disclosure rules that give it a better reputation. The only rationale for mandatory disclosure that really holds up is efficiency.

Identification of efficiency as the paramount rationale for mandatory disclosure suggests a clear principle of statutory reach. Each country should regulate the disclosure behavior of issuers of its nationality and no others. It should not be concerned with where an issuer's shares are traded or what the nationality of the buyers is. This approach assigns to each country regulatory authority over the issuers whose disclosure behavior most affects its welfare. Global welfare will be maximized, because each issuer will be regulated by the country that will benefit most by getting the level of required disclosure right. A switch to the issuer-nationality ap- 
proach will also prevent a kind of regulatory competition that could lead to suboptimally low disclosure levels required by all countries.

For similar reasons, the issuer-nationality approach is also the best approach for the United States in terms of promoting its own welfare. This is so even if other countries do not follow suit. 


\section{APPENDIX \\ The Effect of Labor Saving Better Allocation on the Marginal Product of Labor}

Economists commonly assume when examining economy-wide phenomema that firms have constant elasticity of substitution ("CES") production functions. This requires that the production function (i) is linear homogenous (see supra note [capital saving innovation analogy]) and (ii) has elasticity of substitution (the percentage change in the ratio of marginal products-the marginal rate of substitution-for a given percentage change in inputs) that is constant over the full range of possible input combinations. ${ }^{215}$ An example is the Cobb-Douglas production function, where the elasticity of substitution is 1 .

A CES production function for $\mathrm{X}$ may be expressed in the form

$$
Q_{\mathrm{x}}=\mathrm{X}(L, K)=b\left[\alpha L^{\rho}+(1-\alpha) K^{\rho}\right]^{1 / \rho}
$$

Y's production function, which differs from X's only in that the actual number of units of labor act as though they were a greater number than that of "effective" units, can thus be stated as $Q_{y}=$ $Y(L, K)=b\left[\alpha\left(\mathrm{E}_{\mathrm{L}} \mathrm{L}\right)^{\rho}+(1-\alpha) K^{\mathrm{\rho}}\right]^{1 / \rho}$, where $E_{L}>1$.

The elasticity of substitution for a CES production function can be shown to be $\partial=1 / 1-\rho$. It is usually assumed to be somewhere between 0 (no substitutability) and 1 (unitary substitutability) and thus it is assumed $\rho \leq 0$.

The question of whether a reallocation analogous to a laborsaving innovation increases $m p p_{L}$ is the question of whether $d^{2} Q_{y} /$ $d L d E_{L}>0$. If it is, $d Y / d L=d X / d L$ when $E_{L}=1$ (that is, when $Y(L, K)=X(L, K))$ and $d Y / d L>d X / d L$ for and given $L$ when $\mathrm{E}_{\mathrm{L}}>1$ (as assumed here).

$$
\begin{aligned}
& \frac{d Q}{d L}=b\left[\alpha\left(E_{L} L\right)^{\rho}+(1-\alpha) K^{\rho}\right]^{\frac{1-\rho}{\rho}} \alpha E^{\rho} L^{\rho-1}
\end{aligned}
$$

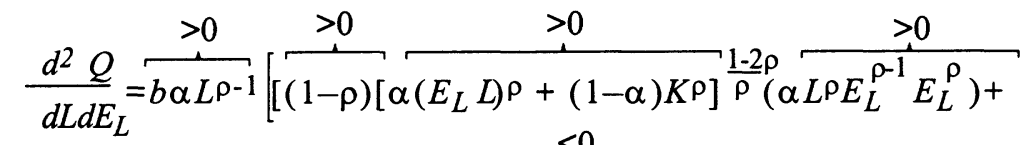

$$
\begin{aligned}
& \left.\underset{\left[\alpha\left(E_{L} L\right)^{\rho+(1-\alpha) K^{\rho}}\right]}{>0} \frac{1-\rho \uparrow}{\rho}\right|_{\rho} ^{<0} \frac{\sum_{L}^{\rho-1}}{E^{-1}}
\end{aligned}
$$

215. See Henderson \& QuANDT, supra note 99 , at $62,85-89$. 
For notational convenience, set

$$
U=(1-\rho)\left[\alpha\left(E_{L} L\right)^{\rho}+(1-\alpha) K^{\rho}\right]^{\frac{1-2 \rho}{\rho}}\left(\alpha L^{\rho} E_{L}^{\rho-1}\right) E_{L}^{\rho}
$$

and

$$
V=\left[\alpha\left(E_{L} L\right)^{\rho}+(1-\alpha) K^{\rho}\right]^{\frac{1-\rho}{\rho}} \rho E_{L}^{\rho-1}
$$

Examination of (2) shows that $U>0, V<0$. Thus

$$
\frac{d^{2} Q_{\mathrm{y}}}{d L d E_{L}}>0
$$

if and only if $\frac{-V}{U}<1$.

$$
\begin{aligned}
\frac{-V}{U} & =\frac{-\rho}{(1-\rho)} \frac{\left[\alpha\left(E_{L} L\right)^{\rho}+(1-\alpha) K^{\rho}\right]}{\alpha\left(E_{L} L\right)^{\rho}} \\
& =\left(\frac{-\rho}{1-\rho}\right)\left[1+\frac{(1-\alpha) K^{\rho}}{\alpha\left(E_{L} L\right)^{\rho}}\right]
\end{aligned}
$$

$(1-\alpha) K^{\rho} / \alpha\left(E_{L} L\right)^{\rho}$, the second part of the expression in brackets, is the ratio of capital's share of national income to that of labor. This is because

$$
\frac{(d Q / d K)}{(d Q / d L)}=\frac{(1-\alpha) K^{\rho-1}}{\alpha E_{L}^{\rho} L^{\rho-1}}
$$

and so

$$
\frac{(d Q / d K) K}{(d Q / d L) L}=\frac{(1-\alpha) K^{\rho}}{\alpha\left(E_{L} L\right)^{\rho}}
$$

Thus, with empirical estimates of the marginal rate of substitution $\partial$ and hence of $\rho=\frac{\partial-1}{\partial}$,

and of the ratio of capital's to labor's shares of national income, we can tell, assuming CES production functions, whether labor saving reallocation will raise or lower the marginal product of labor. 
Labor's share in the United States has been estimated at approximately 0.65 and capital's share at approximately 0.35 .216 Thus, equation (5), which equals the second part of the bracketed expression in equation (4), equals 0.54 . The entire bracketed expression would therefore equal 1.54. Given this, we can see from equation (4) that $-V / U$ will be less than 1 (and hence $m p p l$ will increase with labor saving better allocation) if $(-\rho / 1-\rho)$ is less than 0.65 . This would be true for any value of $\rho>-1.86$ and hence for any elasticity of substitution greater than 0.37 - because the elasticity of the production function equals $1 / 1-\rho$.

Kravis, using a time series analysis, has estimated the "historic" elasticity of substitution of the U.S. economy as 0.64..$^{217}$ Arrow, Chenery, Minhas, and Solow explored various ways of measuring the elasticity of substitution in various sectors of the economy, in the U.S. economy as a whole and transnationally. Using two different time series tests, they developed respective estimates for the nonfarm sector of the U.S. economy of 0.569 and 1.10 .218 They also performed a cross-section analysis involving 24 industries and 19 countries. ${ }^{219}$ The elasticity of substitution in all but one was less than 1.00 , but none were lower than 0.721 . A review of the significance tests of these estimates suggests that most of them would be greater than 0.37 at a ninety-percent confidence level. ${ }^{220}$

Overall, the available evidence suggests that it is very unlikely that the elasticity of substitution in the United States or in other developed economies is less than 0.37 and thus very unlikely that even labor-saving allocational improvements would lower labor's marginal product.

216. See Kravis, supra note 113 , at 925.

217. See id. at 940.

218. See Arrow et al., supra note 113 , at 244-46.

219. Arrow et al. suggest that their industry data in their 19 countries are best explained, not by the assumption that the production function for each industry is the same in every country, but that the industry's elasticity of substitution is the same for every country with the production functions differing only by a factor neutral efficiency factor - in the statement of $X$ 's and $Y$ 's production functions, b. See id. at 234-38, 246.

220. See id. at 227-28. 